\title{
DE POPULAIRE ELEMENTEN IN DE TAAL VAN M. VALERIUS MARTIALIS
}



DE POPULAIRE ELEMENTEN IN DE TAAL VAN M. VALERIUS MARTIALIS 
Promotor:

Prof. Dr H. H. Janssen. 


\section{DE POPULAIRE ELEMENTEN IN DE TAAL VAN \\ M. VALERIUS MARTIALIS}

ACADEMISCH PROEFSCHRIFT TER VERKRIJGING VAN DE GRAAD VAN DOCTOR IN DE LETTEREN EN WIJSBEGEERTE AAN DE R.K. UNIVERSITEIT TE NIJMEGEN, OP GEZAG VAN DE RECTOR MAGNIFICUS Mr. J. W. G. P. JURGENS, HOOGLERAAR IN DE FACULTEIT DER RECHTSGELEERDHEID, VOLGENS BESLUIT VAN DE SENAAT IN HET OPENBAAR TE VERDEDIGEN OP WOENSDAG 18 MEI 1949, DES NAMIDDAGS TE 3 UUR

\section{DOOR \\ Herman Huisintveld}

GEBOREN TE DONGEN. 
Aan mijn Ouders

Aan Marjo 


\section{Literatuurlijst}

B. AXELSON, Unpoetische Wörter, Ein Beitrag zur Kenntnis der Lateinischen Dichtersprache, Lund 1945.

W. BAEHRENS, Skizze der Lateinischen Volkssprache. In: Neue Wege zur Antike, II, p. 43-66, Leipzig 1925.

J. BERTSCHINGER, Volkstümliche Elemente in der Sprache des Phaedrus, Bern 1921.

TH. BIRT, Martiallesungen, Rhein. Mus. 79 (1930), p. 312 vv. H. BLASE, Geschichte des Plusquamperfekts im Lateinischen, Giessen 1894.

P. BRODMUEHLER, De particulis interrogativis nonnullorum scriptorum aetatis argenteae, Bonn 1914.

A. DOLDERER, Ueber Martials Epigramme auf Aertzte, Tübingen 1939.

$\mathrm{DEL}=\mathrm{A}$. Ernout-A. Meillet, Dictionnaire étymologique de la langue latine. Histoire des mots. 2me ed. Paris 1939.

G. FRIEDRICH, Zu Martial. In: Hermes 43 (1908), p. 619 vv.

H. GEORGES, Ausführliches lateinisch-deutsches Handwörterbuch, Hannover-Leipzig I 1913, II 1918.

A. GUDEMAN, Geschichte der lateinischen Literatur, Sammlung Göschen, Berlijn-Leipzig, II 1923.

W. HERAEUS, Zur neueren Martialkritik. In: Rhein. Mus. 74 (1925), p. 314 vv.

J. B. HOFMANN, Lateinische Umgangssprache, Heidelberg 1925; 2. Aufl. 1936.

H. H. JANSSEN, De kenmerken der Romeinsche Dichtertaal, Nijmegen-Utrecht 1941.

J. KRUUSE, L'originalité artistique de Martial. In: Classica et Mediaevalia, IV (1941), p. 248-300.

R. KüHNER-HOLZWEISSIG, Ausfuerliche Grammatik der Lateinischen Sprache, I. Band, Hannover 1912.

R. KüHNER-C. STEGMANN, Idem II. Band, Satzlehre I 1912, II 1914.

P. DE LABRIOLLE, L'emploi du diminutif chez Catulle. In: Revue de Philologie 29 (1905), p. 277-288.

M. LEUMANN, Part. perf. pass. mit fui im späteren Latein. In: Glotta XI (1921),p. 192 vv.

E. LöFSTEDT, Philologischer Kommentar zur Peregrinatio Aetheriae, Uppsala-Leipzig 1911. Anastatischer Neudruck, 1936. 
E. LöFSTEDT, Syntactica. Studien und Beiträge zur historischen Syntax des Lateins, Lund I 1928, II 1933.

H. NELSON, Petronius en zijn „vulgair" Latijn. Een stilistischgrammatische studie over de zoogenaamde "vulgaire dictie" in de Cena Trimalchionis, Alphen aan den Rijn 1947.

E. NEUMANN, De cottidiani sermonis apud Propertium proprietatibus, Königsberg 1925.

A. OTTO, Die Sprichwörter und sprichwörtlichen Redensarten der Römer, Leipzig 1890.

P. PERROCHAT, Pétrone, le festin de Trimalchion; Commentaire exégétique et critique, Paris 1939.

W. PETERS, Phaedrus. Een studie over persoon, werk en taal van den Romeinschen Fabeldichter, Nijmegen 1946.

J. PRAUN, Bemerkungen zur Syntax des Vitruv, Bamberg 1885.

O. RIEMANN, Syntaxe latine 7me ed., Paris 1935.

F. RUCKDESCHEL, Archaismen und Vulgarismen in der Sprache des Horaz, München 1910.

M. SCHANZ-K. HOSIUS, Geschichte der Römischen Literatur, München 1920.

STOLZ-SCHMALZ, Lateinische Grammatik. 5. Aufl. völlig neu bearbeitet von MANU LEUMANN und JOH. BAPT. HOFMANN, München 1938 (Handbuch der Altertums-Wissenschaft II 2). Hierin: SCHMALZ-HOFMANN, Lateinische Syntax und Stilistik.

G. SCHNEIDER, De M.V. Martialis sermone observationes, Breslau 1909.

J. SCHRIJNEN-CHR. MOHRMANN, Studien zur Syntax der Briefe des hl. Cyprian, II. Nijmegen 1937.

A. SEITZ, De Catulli carminibus in tres partes distribuendis. Programm Rastatt, 1887.

E. STEPHANI. De Martiale verborum novatore, Breslau 1889.

G. SüSS, De eo, quem dicunt inesse Trimalchionis Cenae sermone vulgari, Dorpat 1926.

ThLL $=$ Thesaurus linguae latinae, Leipzig 1900. -

O. WEISE, Die griechischen Wörter im Latein, Leipzig 1882.

De door mij gebruikte tekstuitgaven zijn:

L. FRIEDLAENDER, M. Valerii Martialis epigrammaton libri, Leipzig I en II 1886.

M. HERAEUS, M. Valerii Martialis epigrammaton libri, Leipzig 1925.

H. IZAAC, Martial. Epigrammes, Paris 1930-1933.

W. LINDSAY, M. Val. Martialis epigrammata, Oxford 1902. 


\section{Inleiding}

De dichter M. Valerius Martialis, die leefde in de eerste eeuw na Chr. ( \pm 45- \pm 104$)$ en wiens werk tot stand kwam in de laatste decennia van deze eeuw, behoort tot die periode van de Latijnse literatuur, welke wij de Zilveren Latiniteit plegen te noemen. De bloeiperiode der Latijnse poëzie is verstreken. Catullus, Vergilius, Horatius, Tibullus, en de gehele groep der z.g. Augusteissche dichters hebben de modellen geleverd, die voortaan als klassiek zullen gelden. De imitatio, die ontstaan en ontwikkeling der Romeinse dichtertaal heeft beheerst, zal vooral op deze eenmaal aanvaarde modellen betrekking hebben; de invloed van deze dichters blijft in de eerste en in de volgende eeuwen als een rode draad door de geschiedenis der Latijnse poëzie heen lopen. (Voor Martialis vergelijke men de dissertatie van E. WAGNER, De M.V. Martiale poetarum Augusteae aetatis imitatore, Königsberg 1880).

Maar van de andere kant zijn er toch ook geleidelijk belangrijke veranderingen merkbaar. Het werk van de auteurs dezer periode is in menig opzicht duidelijk te scheiden van de literaire producten van de voorafgaande tijd, hetgeen volgens GUDEMAN veroorzaakt werd door redenen van literair-historische, psychische en formeel-rhetorische aard. Met name kunnen we in deze tijd waarnemen een tot-elkaar-naderen van de - voorheen zo scherp gescheiden - dichterlijke en prozaïsche taal; men denke b.v. aan de poëtische inslag in de prozawerken van Seneca, Quintilianus, Tacitus, en aan de rhetorische invloeden in de poëzie van Juvenalis.

LöFSTEDT zegt hierover in zijn commentaar op de Peregrinatio Aetheriae (pag. 97): „Was die sogen. silberne Latinität betrifft, so macht sich ja hier im algemeinen sowohl eine gewisse Verwischung der Grenzen zwischen poetischem und prosaïschem Stil, wie auch das Eindringen gewisser Elemente aus der volkstümlichen Sprache in die litterarische merkbar".

Zeer in het bijzonder dienen we voor deze periode te vermelden de invloed van de rhetorica en van het Grieks op de taal van de Latijnse schrijvers.

Wenden we ons, na aldus de taal van de Zilveren Latiniteit in het algemeen en in grote trekken met enkele woorden geka- 
rakteriseerd te hebben, nu tot Martialis, dan dienen we na te gaan, welke plaats onze dichter inneemt in dit algemeen taalbeeld. Vóór hem had reeds menig Romein zich bewogen op het terrein van het epigram; de gegevens, waarover wij beschikken, zijn te schaars, dan dat wij ons een duidelijk beeld zouden kunnen vormen van wat vóor Martialis reeds op dit gebied was gepresteerd, en zo het al mogelijk is om enige lijnen vast te stellen, waarlangs de ontwikkeling van het Latijnse epigram zich bewogen heeft, dan is het toch practisch onmogelijk te achterhalen, in hoeverre Martialis, in linguistisch opzicht, ontleend heeft aan en onder invloed staat van zijn voorgangers in dit genre.

Wel kunnen we aannemen, dat de ontwikkeling van het epigram vaak langs zeer populaire wegen gegaan is, hetgeen dan ook in de taal ervan zijn sporen achtergelaten zal hebben. We kunnen dit o.a. opmaken uit de volgende passage in de Cena Trimalchionis (c. 55, 2):

„Ita, inquit Trimalchio, non oportet hunc casum sine inscriptione transire", statimque codicillos poposcit et nondiu cogitatione distorta haec recitavit:

„Quod non expectes, ex transverso fit

- et supra nos Fortuna negotia curat.

Quare da nobis vina Falerna, puer."

Ab hoc e pigram mate coepit poetarum esse mentio."

Opvallend is, dat Petronius, zelf 't woord epigramma gebruikend, Trimalchio laat spreken van een inscriptio; al mag men aannemen, dat 't epigram zich ontwikkeld heeft uit de inscripties, dan is 't zeker in de eerste eeuw na Chr. als literair genre toch reeds te ver van zijn oorsprong verwijderd om er nog mee geïdentificeerd te worden; Martialis spreekt alleen van epigrammata.

Bij bestudering van de taal van Martialis blijkt voortdurend, dat hij een typisch vertegenwoordiger is van zijn tijd, al zijn er van de andere kant ook weer trekken in zijn taal, die hem van menig tijdgenoot onderscheiden. Wij bewonderen zijn vindingrijkheid, welke waarlijk niet alleen in de talrijke scherpzinnigheden, spitsvondigheden en geestigheden tot uitdrukking komt, waardoor zijn epigrammen aangenaam en vol genot zijn voor de lezer.

Martialis is door vele banden verbonden met dichters als Catullus, Ovidius en vele anderen. Onze dichter zegt zelf op meerdere plaatsen, dat hij ten zeerste bewondert en wil na- 
streven: Domitius Marsus, Albinovanus Pedo en $\mathrm{Cn}$. Cornelius Lentulus Gaetulicus; vooral echter Catullus, met wie hij gaarne op een lijn gesteld wil worden.

Ten aanzien van de metra nam Martialis zich Catullus ten voorbeeld voor wat betreft de hendecasyllabi en choliamben, Ovidius, en ook wel Vergilius, voor zijn dactyli, al volgde hij hun voorbeeld niet zonder meer. Ook indien Martialis niet duidelijk melding gemaakt zou hebben van zijn samenhang met Catullus, dan zou toch reeds een oppervlakkige vergelijking van vele verzen van Martialis en Catullus ons op de aanwezigheid van een dergelijke band gewezen hebben.

Hierop wil ik echter niet dieper ingaan, daar PAUCKSTADT in zijn werk „De Martiale Catulli imitatore" (Halle 1876) deze zaak uitvoerig belicht heeft.

Hoewel de rhetorische inslag in de literatuur van de eerste eeuw na Christus zeer sterk is, zijn er toch wel enkele schrijvers aan te wijzen, die zich zoveel mogelijk aan deze invloed onttrokken hebben, b.v. Phaedrus in zijn pretentieloze fabels, Petronius in zijn door simplicitas gekenmerkte roman, Suetonius in zijn hofkroniek en verder Celsus en Columella in hun technische en wetenschappelijke geschriften. Hieronder valt ook Martialis. Beperken wij ons tot deze laatste, dan zien we, dat zelfs hij er niet altijd in geslaagd is, zijn gedichten geheel en al te vrijwaren voor genoemde invloed. Nemen we als voorbeeld $\mathrm{V} 24,5$ en 6 :

Hermes, quem timet Helius, sed unum,

Hermes, cui cadit Advolans, sed uni,

waar we een epiphoor vinden, welke stijlfiguur volgens HOFMANN (Umg. Spr. p. 64) gezocht en rhetorisch is en vaak voorkomt bij de „rhetorisch veranlagte” Ovidius. Desalniettemin roept Martialis (IX 73, 8) uit:

„Quid cum grammaticis rhetoribusque mihi?"

En wanneer we hem vergelijken met zijn tijdgenoot Statius, blijkt onmiddellijk, dat het rhetorisch element, inderdaad zoveel als mogelijk, uit het werk van onze dichter geweerd is.

De invloed van de Griekse taal in het algemeen, en van de Griekse epigrammatiek in het bijzonder, is bij Martialis duidelijk aanwezig. Voor dit laatste verwijs is naar het werk van PERTSCH, „De Martiale graecorum poetarum imitatore” Berlijn 1911, en van K. PRINZ, „Martial und die griechische Epigrammatik", Berlijn 1911. Voor het eerste is het echter voldoende Martialis zélf ter hand te nemen, daar op iedere bladzijde 
duidelijk de Griekse invloed spreekt uit zijn vocabularium; E. STEPHANI wijst zelfs vele Griekse woorden aan, welke vóór Martialis nergens gevonden worden bij Latijnse auteurs, ofwel slechts bij prozaschrijvers; hij gebruikt dus niet alleen Griekse woorden, maar biedt ons zelfs meerdere innovaties!

Behoeft de invloed van het Grieks ons op zich al niet te verwonderen bij een auteur uit deze periode, in ons geval is het reeds voldoende te verwijzen naar Martialis' grote voorbeeld Catullus, bij wie we ook menig Graecisme aantreffen.

Dat anderzijds ook metrische behoefte het gebruik van graecismen bevorderd zal hebben, staat wel vast. Beschouwen we b.v. het woord concubinus, dat uiteraard slechts in nietdactylische verzen voorkomt; in de dactylische verzen vinden we in plaats van dit woord, dat hier niet past in het metrum, steeds het Griekse "moechus”. Meer hierover geeft G. SCHNEIDER; zie literatuurlijst.

Tenslotte dan dát element in de taal van Martialis, dat in deze studie speciaal ter sprake zal komen: de omgangstaal. Alvorens verder te gaan is het wellicht dienstig, thans reeds duidelijk aan te geven, wat ik in de hierna volgende bladzijden onder deze term zal verstaan. Ik zou mij hier voorlopig dan willen aansluiten bij de bepaling ervan, zoals die gegeven is door WöLFFLIN, Philologus 34 (1876) p. 137: ,die Umgangssprache in allen ihren Schattierungen, vom sermo familiaris der Gebildeten bis zum sermo plebeius der Gasse". Pas later zullen wij trachten te bepalen, welke plaats Martialis nu precies inneemt binnen deze, vooralsnog ruim getrokken, grenzen.

HOFMANN (Umg. Spr. pag. 4) betoogt, dat Martialis, zoals ook Catullus en Phaedrus, vele elementen aan de omgangstaal ontleend heeft, maar hij gaat hier, enkele weinige voorbeelden uitgezonderd, toch niet dieper op in. Hieraan zou ik willen toevoegen, dat ook Propertius vaak aan de omgangstaal ontleend heeft, zoals E. NEUMANN duidelijk aangetoond heeft in zijn dissertatie "De cottidiani sermonis apud Propertium proprietatibus".

MAURITZ SCHUSTER zegt in Bursian's Jahresbericht 212 (1927) p. $144 \mathrm{v}$, dat Martialis' taal „knapp, volkstümlich und partikelarm" is, maar ook hij gaat hierop niet dieper in.

Ook FRIEDLAENDER richt onze aandacht slechts zelden op die eigenaardigheden, welke Martialis schijnt overgenomen te hebben uit de omgangstaal. Nog vele anderen maken slechts melding van het feit, dat Martialis' taal vaak de omgangstaal 
van zijn dagen weergeeft of benadert, maar geven niet of slechts hoogst zelden aan, wáár en in hoeverre dit gebeurt.

Het doel van deze dissertatie is dan ook te trachten in deze zaak wat meer licht te brengen en het materiaal naar voren te halen, waarop bovenstaande uitspraken, bewust of onbewust, berusten, zoals dit ook door andere dissertaties en voor andere auteurs reeds werd gedaan.

Over de uitvoerig gecommentarieerde uitgave van Martialis' epigrammen, verzorgd door FRIEDLAENDER, wil ik slechts kort zijn. W. HERAEUS (Zur neueren Martialkritik, Rhein. Mus. 74 (1925) p. 314) zegt hierover: „(Der Kommentar) war doch im ganzen eine Enttäuschung, einseitig antiquarisch gerichtet und den Leser oft im Stich lassend". En op pag. 315: „Ein würdiger, Zeitgemässer Kommentar ist dem liebenswürdigen Dichter noch immer versagt geblieben."

Mijns inziens is deze critiek te scherp en is het juister te beweren, dat, met waardering van het wél gebodene, FRIEDLAENDER's uitgave een aanvulling behoeft, o.a. van linguistische aard, omdat, ondanks de vele verhelderende wetenswaardigheden, welke FRIEDLAENDER ons biedt, menige plaats anders toch onbegrepen en duister blijft en niet op haar juiste waarde geschat kan worden. Het is immers niet voldoende te weten, waarover iemand spreekt; we moeten ook kunnen aanvoelen, waarom hị er juist zó over spreekt. En ondanks diverse latere uitgaven, ook ondanks die van HERAEUS zelf, die wel tekstcritisch een grote vooruitgang is, blijkt FRIEDLAENDER nog steeds dé standaard-uitgave van Martialis te zijn! Bovendien mogen we niet vergeten, dat FRIEDLAENDER niet beschikken kon over enige studie betreffende de taal van Martialis. Het eerste tractaat van die aard verscheen pas in 1889 van de hand van E. STEPHANI. En tenslotte zou Martialis zelf meer ingenomen geweest zijn met een uitgave van zijn werken, zoals door FRIEDLAENDER gegeven, dan met een uitgave als door HERAEUS bedoeld( en door mijn studie misschien mede voorbereid), daar Martialis immers zegt (X 21) :

Scribere te quae vix intelligat ipse Modestus

Et vix Claranus, quid, rogo, Sexte, iuvat?

Non lectore tuis opus est sed Apolline libris:

Iudice te maior Cinna Marone fuit.

Sic tua laudentur sane: mea carmina, Sexte, grammaticis placeant, ut sine grammaticis. 
Wellicht dat Martialis mij mijn werk toch wil vergeven, daar hij bovenstaande woorden schreef voor zijn tijdgenoten, die hem ook zonder hulp van de grammatici konden verstaan, terwijl wij, die het Latijn niet meer spreken, zelfs niet meer schrijven, op het werk der grammatici zijn aangewezen.

Het doel van mijn studie is dan ook, een gedeelte van Martialis' taal nader te beschouwen, om aldus, uit bewondering voor deze dichter, het mijne bij te dragen aan het tot stand komen van het zo nodige volledige commentaar; dit tevens om de trots van Martialis, tota in orbe notus te zijn, ook voor ons land waar te maken, waar reeds meer dan drie eeuwen geleden de belangstelling voor deze dichter leidde tot de uitgave van zijn werken en wel door HADRIANUS JUNIUS in 1566, JOHANNES GRUTER in 1596/1602, en PETRUS SCRIVERIUS in 1619/1621. SCALIGER heeft hem zelfs in het Grieks vertaald (1603).

Uit de boven aangehaalde woorden van meerdere geleerden blijkt, dat de taal van M. Val. Martialis duidelijke tekenen van de sermo cotidianus vertoont. Willen wij de oorzaken achterhalen, waaruit dit voortvloeit, dan moeten wij allereerst bedenken, dat Martialis het leven van een grootstad beschrijft, alwaar hij omgang had met vele mensen, zowel van hoge als van lage stand, wier leven hij uitmuntend observeert, welk leven hij waarheidsgetrouw, realistisch en met veel verve weergeeft. Zo komt het, dat wij als in levende lijve voor ons geestesoog zien passeren: senatoren, centurio's, rechters, herauten, werklieden, slaven, dichters, philosophen, dokters en matrones, voor allen echter Martialis zelf!

Bovendien was Martialis "populair" in Rome en ver daarbuiten, getuige zijn grote lezerskring. Want hij was een dichter van zijn tijd, hij schreef over zijn tijd, d.w.z. zijn tijdgenoten. En hij deed dit vóór zijn tijd, voor zijn medemensen; hij had contact met zijn lezers, óók omdat hij schreef in een taal, die van zijn tijd was, die verstaan werd door zijn lezers. Dit doet a priori reeds popularismen vermoeden.

Ook schrijft Martialis in de brief, die aan zijn eerste boek voorafgaat en die we kunnen beschouwen als een inleiding op zijn gehele oeuvre: Epigrammata illis scribuntur, qui solent spectare Florales, en tevens verdedigt hij hier zijn lascivam verborum veritatem, id est epigrammaton linguam. Dat Martialis' epigrammen nauw met het „leven" verbonden zijn, blijkt ook uit de volgende verzen $(\mathrm{X}, 4,8-10)$ : 
Hoc lege, quod possit dicere vita "Meum est". Non hic Centauros, non Gorgonas Harpuiasque Invenies: hominem pagina nostra sapit.

De aanwezigheid van omgangstaalelementen kan ook nog door een andere oorzaak verklaard worden; in de tijd van de zilveren Latinitas is het een algemeen voorkomend verschijnsel, dat omgangstaal-elementen binnendringen in de literaire werken, hetgeen door ons kan begrepen worden, wanneer we bedenken, dat in die tijd de grenzen van het Latijnse taalgebied steeds verder uitgebreid werden en literatoren uit verschillende provincies naar Rome kwamen, zoals ook onze dichter, uit onbemiddelde ouders geboren, vanuit het Spaanse Bilbilis naar Rome kwam in het jaar 64. Het valt niet te verwonderen, dat deze geïmmigreerde elementen niet dat fijne gevoel hadden voor de nuancen der urbanitas, dat door de geboren en getogen Romeinen werd tentoongesteld.

Wanneer we ons rekenschap willen geven van de omgangstaalelementen, die bij Martialis gevonden worden, dienen wij ons allereerst een algemeen beeld te vormen van de omgangstaal zelf, hetgeen ons mogelijk is door het werk van J. B. HOFMANN, Lateinische Umgangssprache. Dit werk stelt echter voornamelijk tendenzen vast en is zodoende voor ons doel te algemeen. Wij zullen ons vergelijkingsmateriaal dan ook voornamelijk moeten zoeken binnen een nauwer begrensd gebied; ik denk b.v. aan Petronius, Phaedrus en de Pompeiaanse inscripties.

Uit deze inleiding, die wel is waar lang, maar naar mijn mening noodzakelijk was, blijkt, welke methode ik bij mijn studie gevolgd heb: steunend op de aanwijzingen, die HOFMANN, LöFSTEDT en vele anderen ons geven, heb ik de taal van Martialis behandeld, welke aanwijzingen ik steeds zoveel als mogelijk en noodzakelijk was, vergeleken heb met onze bronnen voor de omgangstaal van de eerste eeuw na Christus en met die schrijver, waaraan Martialis zoveel ontleende, Catullus.

Als uitgangspunt heb ik steeds genomen de Martialis-uitgave van FRIEDLAENDER, waarnaast ik echter voortdurend de andere, in mijn literatuurlijst genoemde, uitgaven raadpleegde.

Het Epigrammaton Liber, ook wel Liber SPectaculorum genaamd, zal ik kortheidshalve steeds aanduiden met de letters $s p$. 


\section{HOOFDSTUK I}

\section{Enige kwesties van phonetische aard}

De eerste vraag, die we ons bij een systematische behandeling van Martialis' taalgebruik dienen te stellen, zal van phonetische aard zijn: gaat Martialis in het opnemen en toelaten van omgangstaalelementen in zijn epigrammen zóver, dat hij ook de phonetische tendenzen, die in de omgangstaal van zijn dagen aanwezig waren, tot uitdrukking brengt?

H. NELSON behandelt deze kwestie ten aanzien van Petronius zeer uitvoerig en moet dan (pag. 62) concluderen "dat Petronius hoogstens zeer terloops eens phonetische bijzonderheden uit de Latijnsche volkstaal van zijn tijd heeft weergegeven". Hoewel NELSON hier dus spreekt over de volkstaal en ik, zoals reeds in de inleiding gezegd, de grenzen van de omgangstaal vooralsnog ruimer wil trekken, zullen de volgende bladzijden duidelijk maken,dat ook bij Martialis het „populaire” coloriet slechts ten dele bewerkt wordt door de phonetische elementen.

\section{$\S 1$. DE AFWISSELING au : 0.}

Nemen we b.v. allereerst de overgang van de diphthong au in de monophthong $o$. We weten, dat het het lot van de Latijnse diphthongen was, in de loop der tijden te moeten verdwijnen en vervangen te worden door monophthongen. $\mathrm{Zo}_{0}$ is ook de plaats van de tweeklank au langzamerhand gedeeltelijk ingenomen door $o$, en wel het eerst op het platteland en van hieruit in de volkstaal van de stad Rome ${ }^{1}$ ). In het cultuurLatijn en in de omgangstaal van de hogere kringen wist au zich ruimer te handhaven, zo zelfs, dat au, wellicht in geaffecteerde uitspraak, geheel ten onrechte opduikt in bepaalde woorden, waar oorspronkelijk o thuis hoort, al dienen we hiernaast op te merken, dat $o$ in weer andere woorden, ook in de cul-

\footnotetext{
1) Men vgl. A. ERNOUT, Les éléments dialectaux du vocabulaire latin II, Parijs 1828, p. 51vv. Het blifkt dat de overgang van au naar o niet in het gehele Vulgair-Latijn plaats heeft, maar slechts in bepaalde mate onder dialectische, rustieke invloed in het Latijn doordringt.
} 
tuurtaal, een vaste plaats heeft gekregen. Men denke aan een woord als codex, waarnaast ook caudex voorkwam. Afgezien van de vraag, welk van beide uitspraken oorspronkelijk is (vgl. DEL s.v.) kunnen we toch constateren, dat blijkens de teksten, codex zeker niet een meer populair karakter droeg dan caudex.

NELSON deelt ons mede, dat we in Petronius' vulgaire dictie slechts vijf voorbeelden vinden van de overgang au tot $o$; het betreft hier de woorden coda, copo en plodo. Volgens de uitgave van FRIEDLAENDER vinden we cauda zes maal bij Martialis en coda in het geheel niet. HERAEUS en IZAAC daarentegen geven op één plaats (VII 78,1$)$ coda; het critisch apparaat zwijgt hier, zodat het moeilijk is uit te maken, waarop deze verschillende lezingen berusten en een standpunt te bepalen, maar zelfs als coda juist zou zijn, blijft het nog slechts één geval tegenover vijf maal cauda ${ }^{2}$ ).

In FRIEDLAENDERS uitgave vinden we 9 maal de vorm copo en nergens caupo. De ThLL volgt hem in deze, maar HERAEUS en IZAAC, hoewel in de overige gevallen met hem overeenstemmend, geven op één plaats, n.l. III 58, 24, caupo. FRIEDLAENDER zelf had hierbij (deel I, pag. 115) reeds aangetekend: "die Verderbnisse weisen auf caupo; Sinn nicht plebejisch." Misschien geeft juist deze laatste opmerking de verklaring van de schrijfwijze caupo, vooral als we hiernaast andere plaatsen bezien (als b.v. II 51,3 ), waar de betekenis wel "plebejisch" genoemd kan worden. Lezen we dus op III 58, 24 caupo (opvallend is, dat dit de enige plaats in choliamben is) dan staat hiertegenover nog altijd een sterke meerderheid van copo.

Plodo vinden we nergens bij Martialis, wel meerdere malen plaudo en plausus.

Tot nu toe vergeleken we Martialis' taalgebruik met dat van Petronius. In Pompeii werden echter nog enige andere vormen

2) Als Martialis op genoemde plasts inderdaad c od a geschreven heeft, kan dit misschien veroorzaakt zijn door het feit, dat hij in dit epigram de coda lacerti en de conchis als zeer alledaagse spijzen ultdrukkeltjk stelt tegenover meerdere delicatessen. Omgekeerd zou deze overweging ook gebruikt kunnen worden als steun voor de lezing coda, vooral als we hiertegenover plaatsen XIV 67, 2 a lit is eximiae cauda superba (het betreft hier een pauwestaart!). Maar..... in het hiermee corresponderende gedichtje, het geringere geschenk van een arme betreffende, wordt een ossestaart ook cauda genoemd! 
gevonden: olla, obscultat, coliclo, plostrari, Olus en Clodius (zie Nelson, p. 28).

Olla (voor aulla, aula $=$ pot) heeft Martialis drie maal (XII 18, 21; XII 32, 21; XIII 8, 1). Zéér instructief is wel XIII 8, 1, waar hij spreekt van plebeias ollas!

Coliculus komt bij Martialis vier maal voor (dus niet de gesyncopeerde vorm van Pompeii); hiernaast vinden we twee maal caulis (nergens colis!), het primitivum, waarvan genoemd deminutivum werd afgeleid. Coliculus hebben verder nog: Cato agr., Varro rust., Vitruv., Cels., Colum., Pelagon., Chiron., Apic., gloss. Opvallend is verder, dat Martialis (XIII 17) in de titel coliculus gebruikt, maar in het gedicht zelf caulis ${ }^{3}$ ).

Olus ( $=$ Aulus): deze naam komt meerdere malen voor bij Martialis; het meest sprekend wellicht in het smalende epigram VII 10, welk gedicht menig popularisme vertoont.

Onze aandacht verdient verder nog de groep lautus-lotus, welke groep strikt genomen buiten deze beschouwing moet vallen, omdat het hier niet gaat over een woord met twee verschillende schrijfwijzen, maar practisch over twee verschillende woorden; behalve het phonetisch verschil is er immers ook een betekenis-verschil aanwezig; na erop gewezen te hebben, dat het adiectivum verbale van (oud) lavo-lavere lautus is, of met reductie van de diphthong lotus, geeft DEL s.v. lavo het verschil in betekenis tussen deze beide vormen aldus aan:

lautus = „elegant, gedistingueerd;” en vandaar: „rijk, achtbaar." lotus = ,gewassen, gebaad."

Dit onderscheid eenmaal gegeven zijnde, kunnen we dus niet zonder meer zeggen, dat het voorkomen van lotus wijst op een populaire inslag bij een auteur. Het is dan ook op zijn minst onvoorzichtig te noemen, wanneer NEUMANN ten aanzien van Propertius' taalgebruik opmerkt (pag. 15) : „Clarius Propertium summa incuria plebeiam pronuntiationem sequi ex forma lotus pro lautus intelligimus, quae hic primum occurrit atque usque a Vitruvio demum et Seneca (Phaedr.) saepius legitur."

Martialis houdt zich bij het gebruik van beide vormen zeer nauwgezet aan het betekenis-onderscheid. Lotus heeft hij elf

a) De titels zijn er ten behoeve van de lezer boven geplaatst door Martialis om het gebruik van dit boekje te vergemakkelijken. Zou dit in het onderhavige geval geleid hebben tot het gebruiken van de meer populaire naam van deze groente in de titel? Men zou nog kunnen denken an metrische dwang, maar coliculus is evengoed als caulis bruikbaar in dact. 
maal in zijn epigrammen, het negatieve illotus twee maal. Lautus komt bij hem twaalf maal voor. (Men zou zich wel kunnen afvragen, in hoeverre er verband bestaat tussen de (in sommige gevallen geaffecteerde) uitspraak au, waar dit gesproken wordt voor oorspronkelijk o, en de typische betekenis van lautus. Een Hagenaar typeren wij ook wel eens door hem Hêgenaar te noemen. Is iets dergelijks ook in het spel geweest bij het doublet lautus/lotus?

Bij Martialis vond ik verder nog lomentum „zeep" (III 41, 1), welk woord bij onze dichter voor het eerst voorkomt, terwijl uit de latere bronnen het populaire karakter van dit woord duidelijk blijkt.

Naast fauces (het singulare, eenmaal bij Martialis, komt alleen voor in de poëzie van de Keizertijd en in laat-Latijns proza) bestond foces, op welke uitspraak de Romaanse vormen teruggaan. Dit laatste vinden we niet bij Martialis, maar wel het ervan afgeleide focale (XIV 142, 2).

Evenmin als Petronius heeft Martialis overigens in deze alle mogelijkheden benut. Ook bij hem vinden we b.v. alleen auricula, nergens oricula. Wanneer NELSON dan ook tot de conclusie komt, (pag. 29), dat de vormen met o stammen uit de "algemene (ook beschaafde!) Latijnsche omgangstaal”, maar niet "litterair" genoeg waren voor Petronius' urbane dictie, dan kunnen we, sprekend over Martialis, bij wie het materiaal, zoals boven aangetoond, numeriek iets belangrijker is dan bij Petronius, ook niet anders concluderen, dan dat hij in deze heeft toegegeven aan een tendenz van de algemene omgangstaal van zijn tijd. Van een uitgesproken populair element is hier dus wel geen sprake.

\section{§ 2. DE AFWISSELING au : u.}

Evenmin een typisch verschijnsel uit de volkstaal schijnt te zijn de overgang van de diphthong $a u$ in $u$, zoals we deze vinden bij Martialis in cludo en hiervan afgeleide vormen. Gewoon is dit vocalisme in de composita, waarvan we b.v. bij Martialis aantreffen reclusis foribus (VII 62, 1). In de loop van de post-klassieke periode is dit vocalisme echter ook in het simplex doorgedrongen en zo steeds frequenter geworden en hierop berust dan ook de huidige vorm van het Italiaanse chiudere. Het voorkomen van cludere bij de diverse schrijvers wijst echter geenszins op een populair karakter van dit vocalisme, zodat we wel moeten aannemen, dat deze vorm ook in de 
omgangstaal van de hogere kringen gebruikt werd en zodoende ook voor de „betere" auteurs aanvaardbaar was.

Bij Martialis vinden we, volgens FRIEDLAENDER, nergens claudo, maar steeds cludo. LINDSAY, HERAEUS en IZAAC geven echter eenmaal (II 85, 1) clausa, in de overige (20) gevallen vormen met het gereduceerde vocalisme. Hierbij komt dan nog één twijfelachtige plaats, XII 57, 23, waar HERAEUS, steunend op de handschriften van de familie B, latus leest, waarbij hij aantekent, dat familie C clausus geeft, in tegenstelling met FRIEDLAENDER, die in dezelfde familie $\mathrm{C}$ clusus vond en dit ook in zijn tekst opnam!? Desalniettemin overweegt bij Martialis de monophthongische schrijfwijze.

\section{§ 3. SYNCOPE.}

Een ander element, waaraan we hier onze aandacht moeten schenken, is de syncope, waarover HERAEUS (Rhein. Mus. 74, p. 334), voor mij onbegrijpelijk, zegt: „Ganz fremd sind ihm (sc. Mart.) dagegen sog. synkopierte Formen, wie periclum u. ä.". Het volgende zal de onjuistheid hiervan bewijzen.

Vooraf dienen we echter op te merken, dat ook dit verschijnsel, behalve in de volkstaal, waar het voorkomen ervan uiteraard het meest frequent is, toch ook een plaats gevonden heeft in de dichtertaal in het algemeen, een omstandigheid, die het ons niet steeds gemakkelijk zal maken ons standpunt in deze te bepalen ten aanzien van het taalgebruik van onze dichter Martialis, die, in zijn genre, zelfs een hoogtepunt in het dichterschap bereikte.

NELSON, over deze kwestie sprekend (o.c., pag. $35 \mathrm{vv}$ ), behandelt allereerst de vormen balneum, caldus en calfacio, en concludeert dienaangaande, dat Petronius, die alleen deze gesyncopeerde vormen gebruikt, ,met veel minder schroom dan andere auteurs vormen uit de omgangstaal" in zijn Satiricon heeft opgenomen. Bij Martialis vinden we 22 maal balneum (bovendien nog twee maal balneator), nergens balineum en balineator, maar.... hij was dan ook door het metrum gedwongen om deze gesyncopeerde vorm te gebruiken, althans in de dactylische versmaat, daar een opeenvolging van drie korten hier onmogelijk is, al kunnen we hierbij overwegen, dat hij, gezien de vele malen, dat dit woord bij hem voorkomt, blijkbaar niet zoveel bezwaar had tegen het gebruik ervan.

Caldus heeft Martialis vier maal (bovendien driemaal calda), daarnaast op drie plaatsen calidus. Calfacio alleen op XIV 136, 
2; calefacio, dat trouwens weer moeilijkheden voor het metrum oplevert (het is niet absoluut onmogelijk, maar wel op de aangehaalde plaats), lezen we nergens. Dus overwegend de vormen met syncope.

Verder vinden we bij Martialis soldum (IV 37, 4) naast solidum (X 51, 7) vgl. RUCKDESCHEL p. 98; evenals Phaedrus gebruikt hij alleen de korte vormen prendo (2 maal) en deprendo (9 maal) nergens deprehendo. We vinden 2 maal het populaire lamna, terwijl lamina ontbreekt (zie ook Vitr. en Petron.!); vgl. RUCKDESCHEL p. 90. V 78, 10 lezen we lardum voor laridum (fr. lard). Speciale vermelding verdient het uitgesproken populaire tomaculum (= ,saucijsje”), welk woord we, behalve bij Martialis, nog tegenkomen bij Petron., Juv. en Front.; alleen onze dichter echter bezigt de gesyncopeerde vorm tomacla $(I 41,9$.) Typisch is de populaire vorm surpuit in XII 29, 10 en 12, naast de vollere vorm surripuit in VI 72, 6 en XIII 38, 1. Vgl. RUCKDESCHEL p. 109.

Als laatste voorbeeld wil ik dan nog aanhalen de vorm Vesbius (= Vesuvius), door Martialis IV 44, 1 gebruikt. De naam Vesuvius zou met zijn drie op elkaar volgende korte lettergrepen weer ongeschikt geweest zijn voor Martialis' metrum en een oplossing zocht hij niet in de vorm Vesevus, die alleen bij dichters schijnt voor te komen, maar in de vorm Vesbius, waarvan het populaire karakter zoal niet overtuigend uit de syncope, dan toch wel uit de overgang v-b (eerste eeuw n. Chr.!) duidelijk blijkt.

Al zou het mogelijk zijn aan deze reeks van voorbeelden nog het een en ander toe te voegen, het bovenstaande is toch wel voldoende om de eerder aangehaalde uitspraak van HERAEUS te weerleggen, ja zelfs om aan te tonen, dat Martialis, evenals zulks bij Petronius het geval is, in het toepassen van de syncope verder is gegaan dan menig ander auteur, reden waarom we dit verschijnsel zeker in ons onderzoek moesten betrekken.

\section{§ 4. HERI HERE.}

Over het gebruik van de vormen heri en here kunnen we het volgende opmerken: NEUMANN, die in zijn dissertatie spreekt over de omgangstaal-elementen bij Propertius, zegt op pag. 17: „De hac re iam recte iudicavit $P$. Heymann... poetam vulgari aetatis suae sermoni indulgere arbitratus. Quodsi 
poetarum Propertio aequalium usum persequimur, illud here his tantum locis deprehendimus: Hor. Serm. II 8, 2; Ov. am. I 8,23 ; fast. III 852 . In soluta oratione cum ceteri scriptores florentis aetatis semper heri scribunt, tum Cicedo, uno loco excepto (Att. XV 1, 1)." Treffen we here dus slechts zelden aan in de eerste eeuw voor Chr., in latere tijden wordt het gebruik van deze vorm steeds frequenter. Quintilianus, (een tijdgenoot van Martialis!) zegt over de uitspraak van dit woordje (Inst. 1, 4, 8): in "here" neque e plane neque $i$ auditur; en 1, 7, 22 vervolgt hij: ,here" nunc e littera terminamus et veterum comicorum adhuc libris invenio "heri ad me venit", quod idem in epistulis Augusti, quas sua manu scripsit aut emendavit, deprehenditur.

Bij Martialis nu vinden we zes maal here, twee maal heri. In het merendeel der gevallen geeft hij dus de uitspraak van de omgangstaal van zijn dagen weer; heri (I 24, 4; V 58, 8) werpt hier weinig gewicht in de schaal, daar het op beide plaatsen het slotwoord van een pentameter vormt: HERAEUS (Rhein. Mus. 74, p. 334) deelt ons namelijk mede, dat heri bij de Latijnse dichters een vaste plaats had verworven juist in de pentameter. Onze conclusie in deze kan dus zijn, dat Martialis in de regel de omgangstaal volgt, en dat de beide uitzonderingen hierop voor rekening van de dichtertaal komen.

\section{§ 5. CONSONANTEN.}

Tot nu toe besprak ik slechts het vocalische gedeelte van de phonetische kwesties, die voor mijn onderzoek van belang zijn. Hiernaast zou ook nog menig woord te zeggen zijn over de consonantische elementen, maar daar het niet mijn bedoeling is in dit hoofdstuk het onderhavige onderwerp geheel uit te putten, doch slechts enig licht te werpen op Martialis' standpunt in deze, daar voorts een behandeling van de popularismen in de uitspraak der consonanten op grote tekstcritische moeilijkheden stoot (vgl. NELSON) waarvan de behandeling ons te ver zou voeren, wil ik mij beperken tot het geven van slechts enkele - op consonanten betrekking hebbende - voorbeelden.

Allereerst een voorbeeld van metathesis van consonanten: bij Martialis (III 93,7) vinden we het woord corcodilus; zo althans staat het woord in onze teksten, maar de handschriften bieden practisch alle vormen, die ons door SOMMER, Handb. der Lat. Laut- und Formenlehre, par. 122 en 123 gegeven worden (crocodilus, cocodrilus, corcodrilus e.a.). De door de meeste uit- 
gaven gesanctioneerde vorm vinden we voorts nog bij Phaedrus en Macrobius, maar of dit voldoende reden is om aan te nemen, dat dit dan wel de populaire of algemeen-gangbare uitspraak geweest zal zijn, valt te betwijfelen.

Van weer andere aard zijn de assimilatie-tendenzen die evenals de zojuist besproken metathesis sterk werkzaam zijn in de omgangstaal. Zo lezen we I 109, 1vv: Issa, als naam van het lievelingshondje van Publius. Deze naam is volgens BUECHELER afgeleid van ipsa (= domina), door assimilatie tot issa geworden, een vorm, die we ook in Pompeii aantreffen. Iets dergelijks is het geval met (het wel populaire) susum, door assimilatie en daarna vereenvoudiging van de geminata na lange vocaal ontstaan uit sursum. Petronius biedt ons hiervan één voorbeeld; FRIEDLAENDER geeft ons voor Martialis op I 96, 11 (in choliamben en obscene omgeving) susum, waarbij hij steunt op de cod. MEXABFG, terwijl HERAEUS sursum leest, steunend op cod. PQ (d.w.z. fam. B.!). Moeten we hier de voorkeur geven aan het in meerdere manuscripten (enkele van fam. C.) vertegenwoordigde susum, dat bovendien de contekst aan zijn zijde heeft, of aan het in de (vaak betere) fam. B. aanwezige sursum?

Ook aan het begin van de woorden ondergaan consonantgroepen vaak verandering in de volkstaal. Martialis heeft XII

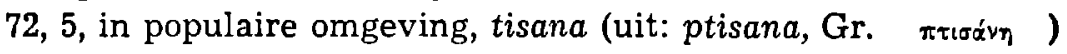
(zo ook Plin., Apic., Non.) Hier hebben we vrijwel zeker te doen met de in de volkstaal gebruikelijke uitspraak, daar het Latijn immers aan het begin der woorden normaliter de groep pt niet spreekt (DEL s.v. tisana; STOLZ-LEUMANN Gr. 146). Hiernaast vinden we echter Mart. XI 21, 7: phthisico cinaedo. (aldus FRIEDLAENDER; HERAEUS heeft pthisico) dus in een verbinding, waar het populaire tisicus, dat we bij Petronius $(64,3)$ vinden, zeker op zijn plaats geweest zou zijn.

En zo laat juist dit laatste voorbeeld ons nog eens duidelijk zien, in hoeverre Martialis van phonetische middelen gebruik maakt om zijn gedichten een bepaalde kleur te geven. Hij volgt hierin geen strakke lijn, maar zet slechts hier en daar een kleur aan; een kleur, die in betrekkelijk weinig gevallen het felle van de volkstaal weergeeft, maar meestal ontleend is aan het iets rustigere kleurenschema, zoals dit het duidelijkst sprak tot de middelklasse van Rome's bevolking, waartoe ook wel de meeste lezers van Martialis' epigrammen behoord zullen hebben. 


\section{HOOFDSTUK II}

\section{Het Vocabularium}

\section{§ 1: DE INTERJECTIES.}

De interjecties, waarover HOFMANN onmiddellijk na de inleiding handelt in zijn Lateinische Umgangssprache en welke KAINZ (Psychologie der Sprache) „Randerscheinungen der Sprache" noemt, hebben zeer vaak een affectief karakter, reden waarom ze vooral in de omgangstaal gebruikt worden.

Voor het doel, dat wij ons in deze studie gesteld hebben zal deze paragraaf niet doorslaggevend zijn, maar hij kan wel dienen als steun voor de overige argumenten.

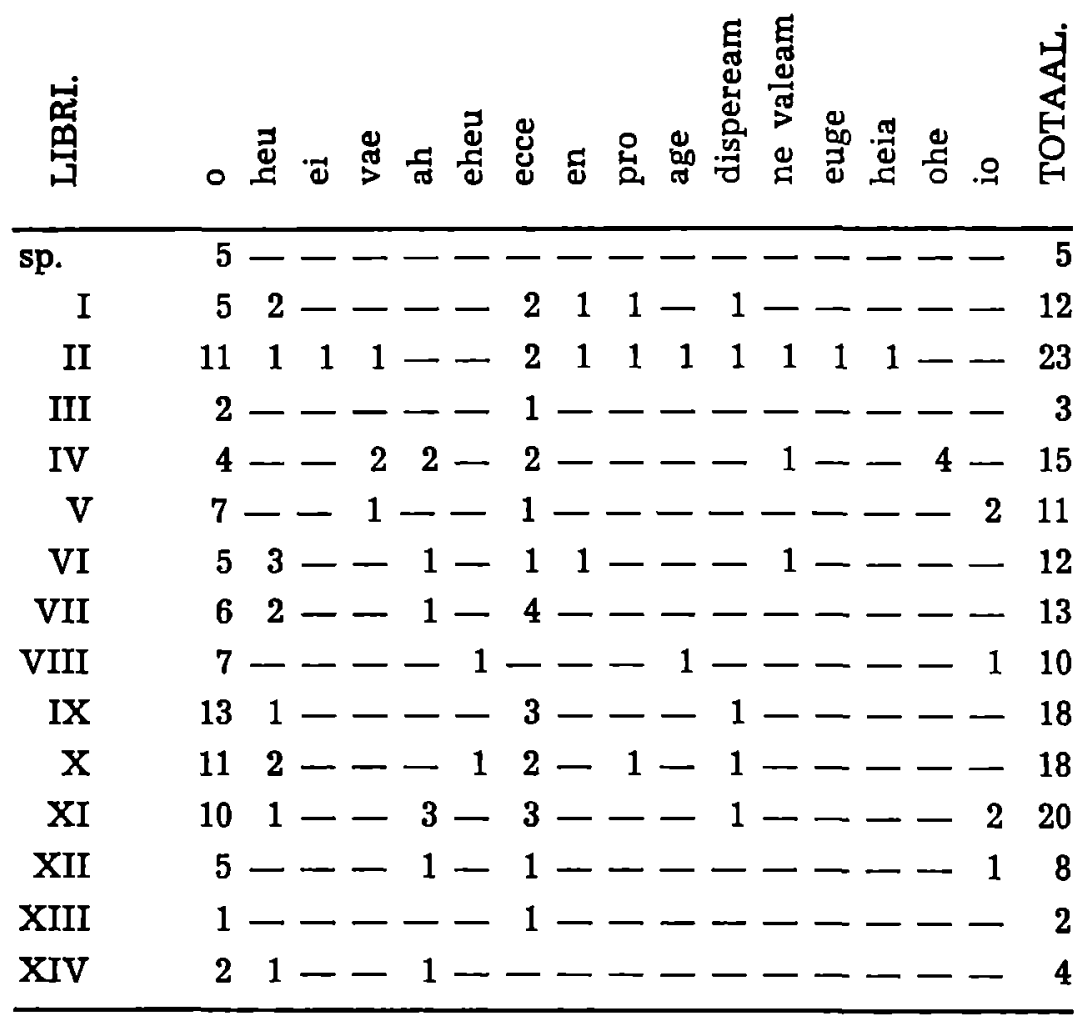

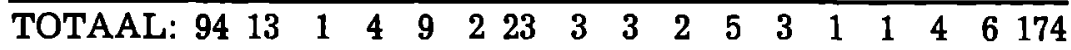


Het vorenstaande schema laat zien, welke interjecties bij Martialis voorkomen en hoe vaak, terwijl tevens haar verdeling over de verschillende boeken erin tot uitdrukking komt.

Bezien we allereerst de interjecties, die de grootste frequentie vertonen, dan vinden we hieronder slechts ecce als secundaire (d.w.z. van een bestaande stam afgeleide) interjectie, terwijl de andere primair zijn. Pas hierna volgen de interjecties, die aan het Grieks ontleend zijn; bij Martialis nemen deze laatste dus niet zo'n belangrijke plaats in.

In het licht van KAINZ's betoog, dat de secundaire interjecties in de meer verheven taal talrijker zijn dan de primaire, krijgt de voorkeur, welke Martialis blijkbaar bezit voor de primaire interjecties, enige betekenis, hoewel we ons hierbij dienen te realiseren, dat de grotere frequentie van de primaire interjecties bij Martialis vooral tot stand komt door de interjectie $o$, die - al is het grootste deel der interjecties, met name in de geschreven taal, na verloop van tijd conventioneel en stereotyp geworden - relatief genomen het meest van alle mechanisch geworden is.

HOFMANN (Umg. Spr. p. 20) zegt: „In der späteren Zeit verschwindet oh fast ganz aus den Handschriften und demgemäss aus den Texten, während o selbst.... im Zusammenhang mit dem Zurücktreten von heus, ehem, eho sich stark ausbreitet."

Zeer duidelijk worden deze woorden reeds door Martialis waar gemaakt, zoals enerzijds blijkt uit het zo-even behandelde, en anderzijds uit de totale afwezigheid van heus, ehem en eho bij Martialis.

Ten aanzien van heu kunnen we opmerken, dat deze interjectie vooral in de verheven poëzie voorkomt, maar van de andere kant toch ook door Petronius gebruikt wordt, waardoor de waarde van deze interjectie voor mijn onderzoek misschien weer enigszins stijgt.

Eheu, dat volgens DEL s.v. een expressieve versterking van heu kan zijn, schijnt een zeer populair karakter gehad te hebben. Martialis heeft er geen voorkeur voor.

De interjectie vae komt bij Martialis, zoals ook bij Plautus, slechts voor in verbinding met de dativus van het pronomen personale (vae tibi).

De frequentie van ecce wordt steeds groter in „volkstümlich gefärbten Texten” (HOFMANN, p. 34); zo bijv. bij Rhet. ad Her., Cic. epist.; vooral echter in de post-klassieke periode 
(Petron.); dit gegeven zijnde, heeft het misschien wel enige betekenis, dat de interjectie ecce bij Martialis ten aanzien van de frequentie de tweede plaats inneemt.

Euge, dat voordien voornamelijk in de taal van de comici zijn plaats heeft, wordt in de post-klassieke periode, met uitzondering van Persius en Martialis, slechts door de Christelijke auteurs gebruikt.

Hoewel HOFMANN p. 25 zegt, dat de aanwezigheid van de interjectie io allerminst bewijst, dat deze uitroep in de omgangstaal is overgegaan, verdient het toch onze aandacht, dat de verbinding io Saturnalia én door Martialis (XI 2,5) én door Petronius (c. 58, 2) gebezigd is; ook HOFMANN schijnt voor deze plaats bij Petronius een uitzondering te willen maken.

Martialis meet de interjectie ohe als een spondaeus (hetgeen overeenkomt met het Griekse $\dot{\omega}_{1}^{\prime}$ ), ofschoon alle andere dichters (Horatius uitgezonderd) haar steeds als een jambe gebruiken. Overigens zegt het wel iets, dat de formule „ohe, iam satis est", die ook bij Plautus frequent is, hier bij Martialis terugkeert: IV 89, 1: „ohe, iam satis est, ohe, libelle.” Vgl. ook Hor. sat. I, 5, 12.

Vervolgens zullen we enige woorden moeten wijden aan de interjectie sophos, welke de Romeinen aan het Grieks ontleend hebben; dit woord heb ik in boven-staand schema niet opgenomen, omdat Martialis het niet als interjectie, maar als substantivum gebruikt heeft; ik vond dit woord zes maal bij Martialis; opvallend is, dat het slechts eenmaal met het adjectief magnum verbonden is (I 76, 10), driemaal echter met grande (I 3, 7; I 49, 37; VI 48, I). Men herinnere zich hier, wat LöFSTEDT (Komm. Peregr. p. 73) zegt over de verhouding van magnus en grandis in de latere Latiniteit!

De interjectie mehercules heb ik in mijn schema niet opgenomen, daar deze niet in Martialis' epigrammen gevonden wordt, maar wel in de brief, die aan het tweede boek voorafgaat. Het heeft echter voor ons toch zijn betekenis, dat Martialis ons juist deze populaire vorm biedt; het schijnt immers, dat de vorm mehercule bij voorkeur in de verheven taal, mehercules daarentegen in de omgangstaal gebruikt werd. Cicero zegt immers (Orat. 47, 157): libentius dixerim mehercule quam mehercules. Ook Petronius schijnt dit onderscheid te bewaren. Apuleius gebruikt in zijn Metamorphoseon libri, met uitzondering van twee plaatsen, waar hij hercule heeft, steeds de vorm 
(me)hercules; maar in zijn rhetorische werken lezen we allcen herc(u)le. Deze gegevens zijn reeds bij FRIEDLAENDER p. 238 te vinden.

Hoewel de interjectie agedum bij Martialis (XI 56,9) gevonden wordt, heb ik gemeend haar hier toch buiten beschouwing te moeten laten, daar NEUMANN in zijn dissertatie p. 22 zegt: „Haud scio, an iure eam (sc. formam agedum) sermonis vulgaris propriam esse existimemus". Voorzichtigheidshalve is het dus beter dit woord vooralsnog niet in ons onderzoek te betrekken.

Vers II 27, 3 luidt:

„effecte! graviter! Cito! nequiter! euge! beate!”

In plaats van cito leest SCHNEIDEWIN st! ("Cito ist als Akklamation weder bekannt noch denkbar.") en hierbij steunt hij dan op de codex Palatinus en op enige andere, minder belangrijke manuscripten. (Ook in vers V 25, 2 heeft hij st!, hier in de plaats van de imperativus sta.) FRIEDLAENDER leest cito, welke vorm hij tot de interjecties schijnt te rekenen, omdat hij hem wil verbinden met het Italiaanse zitto, hetgeen echter om phonologische redenen onmogelijk is; volgens MEYERLüBKE, rom. etym. Wtb. s.v. st, zou zitto juist uit st! ontstaan zijn! Het schijnt mij dan ook beter HERAEUS te volgen, die cito beschouwt als een adverbium, dat aan de taal van de rhetoren ontleend is en dat betekent "kort en bondig" (cf. Cl. Don. interpr. Verg. VII 215: quam cito et quam breviter totum dixit; zie vooral ook Martialis zelf VII 34, 4: dicam, sed cito.)

Dat ik wel de vormen dispeream en ne valeam in mijn schema heb opgenomen, kan als volgt verklaard worden: de man uit het volk doemt zich bij het geven van een krachtige verzekering gaarne ten dode, waardoor uitdrukkingen als zo-even vermeld een populair karakter dragen; zo oordeelt ook HOFMANN, die (p. 31) deze formules tezamen met de secundaire interjecties behandelt.

Behalve naar de boeken zou men de interjecties ook naar de versmaten kunnen indelen. De versmaten, door Martialis voornamelijk gebruikt, zijn: dactyli (hexameters en pentameters), hendecasyllabi en choliamben; van weinig belang, wijl zeer gering in aantal, zijn de sotadaei en jambische senarii, welke metra om hun geringe frequentie door mij bij de hendecasyllabi zijn meegeteld. Aldus krijgen we dan het volgende schema: 


$\begin{array}{lrrrrr}\text { metrum: } & \text { hexam. } & \text { pentam. } & \text { chol. } & \text { hend. } & \text { totaal: } \\ \text { o } & & & & & \\ \text { heu } & 92 & 21 & 10 & 21 & 94 \\ \text { ci } & 9 & 3 & - & 1 & 13 \\ \text { vae } & 1 & 1 & - & - & 1 \\ \text { ah } & 6 & 2 & - & 2 & 4 \\ \text { eheu } & - & 1 & - & 1 & 9 \\ \text { ecce } & 7 & 14 & 1 & 1 & 23 \\ \text { en } & 2 & - & - & 1 & 3 \\ \text { pro } & - & 3 & - & - & 3 \\ \text { age } & 2 & - & - & - & 2 \\ \text { dispeream } & 1 & 4 & - & - & 5 \\ \text { ne valeam } & 3 & - & - & - & 3 \\ \text { cugre } & 1 & - & - & - & 1 \\ \text { hcia } & 1 & - & - & - & 1 \\ \text { ohe } & - & - & - & 4 & 4 \\ \text { io } & 3 & 3 & - & - & 6 \\ \quad- & - & -- & -- & - & - \\ \text { Totaal } & 78 & 53 & 11 & 32 & 174\end{array}$

Hierbij kunnen we het volgende opmerken: STEPHANI (inleiding) deelt ons mede, dat Martialis 3376 hexameters, 3300 pentameters, dus tezamen 6676 dactylische verzen geschreven heeft; bovendien heeft hij 790 choliamben, terwijl het aantal hendecasyllabi 2121 bedraagt (hierbij inbegrepen dus de 69 verzen, in voor Martialis zeldzame versmaten geschreven). Derhalve is de verhouding der aantallen dactyli en choliamben als $17: 2$. Berekenen we eveneens de verhoudingsgetallen van de interjecties, die in deze versmaten voorkomen, dan blijkt hun verhouding te zijn: $22: 2$. Dus is het aantal interjecties, in dactyli voorkomend, groter dan dat van de interjecties, door Martialis in choliamben gebruikt.

De verhouding van de dactyli en hendecasyllabi is als $19: 6$. Voor de interjecties in deze versmaten blijken na berekening de verhoudingsgetallen $24: 6$ te zijn. Dus ook hier zijn de dactyli weer ver in de meerderheid. Onze conclusie luidt derhalve: in verhouding komen de meeste interjecties voor in de dactyli, terwijl ze het minst frequent zijn in de choliamben; tussen beide in staan de hendecasyllabi.

Hoewel we a priori hadden kunnen verwachten, dat juist in de beide laatstgenoemde versmaten de interjecties (zoals ook 
de andere omgangstaalelementen) het talrijkst vertegenwoordigd zouden zijn, blijkt dit in feite niet het geval te wezen. Ook de verdeling naar de verschillende boeken schijnt weinig vruchtbaar te zijn (zoals mij ook voor andere - nog te bespreken - verschijnselen gebleken is) maar hierop zal ik in mijn conclusies nog nader terugkomen. Beide manieren van indeling heb ik hier echter willen geven, en behandelen, om het wezen en de bedoeling ervan voor het nog volgende duidelijk te maken.

\section{§ 2: DE DEMINUTIVA.}

Wanneer we bij SCHNEIDER p. 43 lezen, dat de deminutiva, voor welke woorden met name de omgangstaal een speciale voorkeur heeft, door Horatius meer gebezigd worden in zijn Satyren dan in zijn Carmina, door Vergilius meer in de Eclogae dan in de Aeneis, door Catullus meer in de korte gedichtjes, die hij zelf als nugae en ineptiae betitelt, dan in de "geleerde" stukken; wanneer we o.a. bij LöFSTEDT (Komm. Peregr. p. 310) en BERTSCHINGER p. 19 lezen, dat de deminutiva, vooral in de omgangstaal, vaak hun oorspronkelijke, d.w.z. deminutieve en/of meer-affectieve betekenis verloren hebben en dan dikwijls dáár gebruikt worden, waar noch aan kleinheid noch aan enige subjectieve nuance gedacht wordt; kortom, wanneer uit de vele verhandelingen, over deminutiva geschreven, de speciale plaats, welke deze categorie van woorden in de omgangstaal, en zeer speciaal in de volkstaal en verschillende groepstalen inneemt, wel zeer duidelijk blijkt, mogen we bij een onderzoek naar de invloed van de omgangstaal op de taal van Martialis zeker niet zonder meer aan de deminutiva voorbij gaan, te meer, waar ze door onze dichter zo opvallend vaak gebruikt worden; bij Martialis vinden we n.l. \pm 100 deminutiva, met een totale frequentie van meer dan 400 .

Vanzelfsprekend zijn niet alle woorden, in dit hoofdstuk thuis horend, even belangrijk voor ons onderwerp; in dergelijke gevallen wil ik dan ook volstaan met het vermelden van het woord zonder meer; slechts bij die woorden, die in verband met de te trekken conclusies van belang zijn, zal ik de gegevens vermelden, waarop deze conclusies berusten.

\section{a. EIGENNAMEN.}

Allereerst dan enkele opmerkingen betreffende de Eigennamen, welke we bij Martialis in zo grote getale antreffen. Hierbij 
mocten we onderscheid maken tussen de namen van reëele, en die van gefingeerde personen $\left.{ }^{\mathrm{J}}\right)$. De eerste groep wil ik buiten beschouwing laten, omdat Martialis hier, gebonden als hij was aan de werkelijke naam van zijn figuren, slechts bij uitzondering de deminutief-vorm van deze namen voor speciale doeleinden gebruikt. Belangrijker zijn echter die namen, die Martialis zclf vormt, dan wel, puttend uit de grote voorraad van in zijn tịjd bestaande namen, geeft aan zijn al dan niet gefingeerde personen. Hier immers is hij vrij om zijn keuze zo te bepalen, clat ook de eigennaam een aparte functie in zijn epigrammen vervult. Het is duidelijk, dat in erotisch getinte en affectief gekleurde gedichten (waarvan de inhoud menigmaal zeer laagbij-de-gronds en obsceen is) de deminutief-vorm van een cigennaam kan bijdragen tot de verhoging van het gezochte coloriet.

Zo vinden we de namen Magulla en Maronilla resp. in XII 91 en I 10, beide gedichtjes met erotische inhoud; een vrouw, die zich leent tot minderwaardige praktijken, wordt in X 55 Marulla genoemd. Een affectieve nuance vinden we op de volgende plaatsen, waar de, wellicht bewuste, keuze van de eigennamen geslaagd mag heten: VIII 44, 3 miser Titulle ,arm Titus-je"; VIII 33, 17 vetula Fabulla (men lette ook op de deminutiefvorm van het adjectivum!); typerend is ook III 93, 1, waar Martialis met een zekere afkeer een oud, lelijk, afgeleefd vrouwtje Vetustilla noemt.

Uit deze en andere voorbeelden blijkt dus, dat Martialis, voor zover het de persoonsnamen betreft, zich nog ter dege bewust is van de speciale kracht van de deminutief-vorm. Daar echter, waar hij graag gebruik zou willen maken van de deminutiefvorm, maar erin gehinderd wordt door het feit, dat door het veelvuldige gebruik van een bepaalde naam de deminutieve kracht ervan verzwakt is, bezigt hij een versterkend adjectivum. Zo noemt hij het driejarig zoontje van de bekende redenaar Regulus in VI 38, 1 parvus Regulus, ter onderscheiding van zijn vader én ter aanduiding van zijn kleinheid.

Dit alles neemt echter niet weg, dat er soms ook een andere reden aanwezig schijnt te zijn voor het gebruik van de deminutief-vorm. $Z_{o}$ is wellicht de opeenstapeling van geminatae

4) Hicrbij steun ik op de desbetreffende lijjst, welke FRIEDLAENDER. dl. II, p. 373, geeft onder de titel „Wirkliche und fingirte Privatpersonen aus Martials Zeit". 
bewust gezocht in V 77, 1 Narratur belle quidam dixisse, Marulle. ${ }^{5}$ )

\section{b. ADJECTIVA.}

Van speciale waarde zijn de deminutiva der adjectiva, én omdat ze niet zo talrijk zijn én omdat ze, in het algemeen gesproken, wel meer populair ziin dan die van de substantiva; met name in de meer verheven poëzie zijn ze zeer schaars vertegenwoordigd, cf. AXELSON p. 43. Bij Martialis vinden we de volgende:

albulus: dem. v. albus. XII 98, 4: albula freta. Hoewel FRIEDLAENDER Albula opvat als een eigennaam, bewijst STEPHANI p. 74 (voetnool), dat we het als adjectivum moeten verstaan. Dit deminutivum vinden we bij Catul., Mart., Varro rust., Macr. sat.

bellus: dem. v. bonus. Het is, naar het oordeel van meerdere auteurs, een woord uit de sermo cotidianus, vooral omdat het een typisch affectief karakter heeft. In de hogere poëtische taal wordt het slechts bij uitzondering toegelaten; in de populaire taal vervangt het op den duur pulcher en gaat dan ook over in de Romaanse talen (fr. beau). Hoewel Martialis pulcher nog vaak heeft, gebruikt hij bellus toch reeds 18 maal en het adverbium belle 17 maal. Bellus wordt oorspronkelijk alleen gezegd van vrouwen en kinderen, later ook van mannen, maar dan slechts ironisch. Zo ook bij Mart. I 64, I bella puella (= pulchra p.); maar XII 39, 4 Sabelle belle! (spottend). Het onderscheid tussen adv. bene en belle is bij Martialis nog duidelijk aanwezig, zoals o.a. blijkt uit II 7, 7 nil bene cum facias, facias tamen omnia belle.

crispulus: dem. v. crispus. Het grondwoord heeft Martialis slechts éénmaal, het deminutivum (dat bij hem voor het eerst in poëzie voorkomt) drie maal, steeds met een minachtende, smalende bijbetekenis, b.v. V 61, 1 crispulus iste, quis est?

gemelius: dem. v. geminus. Volgens DEL is het deminutivum vooral poëtisch, omdat het meer teder en expressief is dan het grondwoord. Hiervan kunnen we echter bij Martialis niets bespeuren. Zie b.v. XII 49,12, waar gesproken wordt van gemelligrandes uniones.

Graeculus: dem. v. Graecus. II 86, 3 nusquam Graecula quod recantat echo. Martialis, de eerste auteur, die dit deminutivum

5) Men vergelijke hiervoor 0.a. I 109, 11: gutta pallia non fefellit ulla. 
in poëzie gebruikt, wil hiermede uiting geven aan zijn minachting; het woord heeft dus een affectieve bijbetekenis.

horriadulus: dem. v. horridus. Het deminutivum, ook bij Plautus en Lucilius voorkomend, behoort, aldus DEL, tot de familiaire taal. Martialis heeft het alleen X 98, 9 filios horridulos, rudes, pusillos. Gebruikt Martialis de deminutief-vorm hier om het affectieve karakter te verhogen, of onder invloed van het volgende pusillos?

misellus: dem. v. miser. Volgens DEL een „dim. de tendresse." Martialis heeft het IV 28, 7; VIII 81, 8; III 7, 1 (een epigram met meerdere popularismen); XII 77, 7 (humoristisch-populair getint); op alle plaatsen dient het om het affect te verhogen, hoewel het onderscheid met miser gering is.

parvulus: dem: v. parvus. Martialis bezigt het twee maal, n.l. V 34, 3 parvula Erotion en X 92, 13 parvuli agelli. Op beide plaatsen dus ter versterking van het substantivische deminutivum, waartoe het grondwoord parvus blijkbaar niet voldoende geacht wordt door Martialis. Of gebruikt Martialis parvulus hier juist onder invloed van het volgende deminutivum en hebben we hier een geval van „regressieve assimilatie?” Hoe het ook zij, de deminutief-vorm van een woord, dat op zich reeds een kleinheid aanduidt, getuigt zeker van een populair karakter.

pusillus: dem. v. pusus. Deze deminutief-vorm, hoewel in alle perıcden van de Latiniteit gebruikt, behoort toch voornamelijk tot het familiaire vocabularium. Ook hier hebben we weer te doen met een deminutivum, waarvan het grondwoord reeds een kleinheid aanduidt. Martialis gebruikt pusillus elf maal.

putidulus: dem. v. putidus. Martialis heeft dit deminutivum in IV 20, welk epigram ik hier in zijn geheel laat volgen:

Dicit se vetulam, cum sit Caerellia pupa:

Pupam se dicit Gellia, cum sit anus.

Ferre nec hanc possis, possis, Colline, nec illam:

Altera ridicula est, altera putidula.

Hier speelt Martialis met de tegenstellingen, met de rijmende namen (Gellia-Caerellia), met de woorden vetula-pupa/pupaanus (allen woorden uit de familiaire taal), misschien ook met de klanken (opeenhoping van de geminatae in vers 3 ) ; hiermede volkomen in overeenstemming is het woordenspel ridiculaputidula in het laatste vers. Putidulus, vóór Martialis bij geen enkele auteur voorkomend, is het deminutivum van putidus, een woord, dat door BIRT ${ }^{4}$ ) gerekend wordt tot de vulgaire

i) TH. BIRT, Martiallesungen, Rhein. Mus. 79 (1930), p. 312 vv. 
krachtwoorden, en dat als zodanig voorkomt bij Plautus, Hor. sat., Catull., Petron. Ook STEPHANI is van mening, dat Martialis dit deminutivum op de eerste plaats gebruikt omwille van het woordenspel, dus niet om de deminutieve betekenis als zodanig.

quantuluscumque: dem. v. quantuscumque. XI 14,1 terra quantulacumque „zelfs het kleinste hoopje zand (is te zwaar)". Hier is de deminutieve betekenis dus duidelijk aanwezig.

rancidulus: dem. v. rancidus. Het deminutivum vinden we, behalve bij Martialis (VII 34, 7) o.a. ook bij Juv. De genoemde Martialisplaats is sterk affectief geladen, en behoort bovendien tot een epigram, dat meerdere popularismen bevat.

rubellus: dem. v. ruber. Komt pas voor in de Keizertijd en betekent bij Martialis ,een klein beetje rood”: I 103, 9 et Veientani bibitur faex crassa rubelli.

rusticulus: dem. v. rusticus. Het deminutivum, dat zeker behoort tot de familiaire taal, komt bij Martialis voor het eerst voor in poëzie en wel in XIII 76 (lemma) : rusticulae (substantivisch gebruikt). Opvallend is, dat Martialis hier als titel (die, als alle andere titels, diende om de lezer het gebruik van dit boek te vergemakkelijken) het deminutivum plaatst, terwijl we in het eerste vers van genoemd epigram rustica lezen. Zouden we hieruit misschien mogen concluderen, dat, althans voor Martialis' gevoel (en dat is toch de maatstaf, waarmee we dit alles moeten meten), het verschil tussen grondwoord en deminutivum in deze zeer gering is en dat hij slechts ten behoeve van zijn ruime lezerskring het deminutivum in de titel plaatst? Indien deze veronderstelling juist is, zou het deminutivum de meest gangbare vorm geweest kunnen zijn!

$\mathrm{X} 19,2$ non rusticulum nimis libellum; hier staan dus én adjectivum én substantivum in de deminutief-vorm; bij het adjectivum is de deminutieve betekenis echter geheel afwezig, zoals het toegevoegde adverbium nimis bewijst.

sellariolus: dem. v. sellarius. Het deminutivum komt alleen bij Martialis voor, aldus FRIEDLAENDER en STEPHANI, en wel in V 70, 3, in welk (populair) epigram we voorts nog woorden vinden als popina, balnea, gula, comedere.

vetulus: dem. v. vetus. Vetus is vertegenwoordigd in de Romaanse talen, maar minder dan zijn deminutivum, dat thuis hoort in de familiaire taal (Plaut., Cic., ep., Phaedr., Petron.) Het deminutivum duidt nooit op een kleinheid, maar is vrijwel 
steeds affectief geladen. Als adjectivum gebruikt Martialis het 13 maal, o.a. I 41, 13 quod bucca est vetuli dicax cinaedi, dus in een wel zeer populaire omgeving.

VIII 33, 17 vetulae Fabullae (obscene omgeving).

I 18, 1 vetulo Falerno (,een oud wijntje"); zo ook VIII 77, 5; XI 26, 3 .

Soms schijnt het geheel gelijk te zijn aan vetus, b.v. XI 84, 14 . Het vrouwelijke vetula vinden we bij Martialis 7 maal als substantivum; het wordt dan steeds met een hatelijke, verachtende betekenis gezegd van vrouwen, wier sexuele vermogens sterk verminderd zijn; b.v. III 76, 1 arrigis ad vetulas, fastidis, Basse, puellas; men lette hier op de tegenstelling met puella, dat eigenlijk ook een deminutivum is. Vetula lezen we ook in het reeds eerder vermelde epigram IV 20 , en wel in vers 1 , waarop in het volgende vers anus volgt; hier hebben we dus weer een van de vele gevallen van variatio. Naast vetulus lezen we vetus zeer vaak, maar slechts zelden in een zo duidelijk populaire omgeving.

Tot zover de adjectivische deminutiva. Hierbij zijn er meerdere, (n.l. albulus, bellus, gemellus, misellus, parvulus, pusillus, vetulus), welke onze dichter gemeenschappelijk heeft met Catullus. STEPHANI meent zelfs, dat Martialis albulus en gemellus van Catullus heeft overgenomen, maar het lijkt mij practisch onmogelijk dit met zekerheid te bewijzen. Het feit overigens, dat beide, in menig opzicht verwante dichters, deze woorden gemeenschappelijk hebben, is reeds belangrijk genoeg.

Wijst de deminutief-vorm van adjectiva, in het algemeen gesproken, reeds in de richting van de omgangs- - en soms zelfs populaire taal, bij Martialis bleek dit vaak zelfs zeer duidelijk; opvallend is, dat de genoemde woorden slechts betrekkelijk zelden een kleinheid aanduiden, maar bijna steeds in dienst staan van het affect; opvallend is ook, dat in meerdere gevallen het adjectivische deminutivum zijn voorkomen te danken schijnt te hebben aan een volgend substantivisch deminutivum bij wijze van regressieve assimilatie.

\section{c. SUBSTANTIVA.}

De deminutiva van substantiva zijn bij Martialis in zo grote getale aanwezig, dat het, binnen het bestek van deze studie, niet mogelijk is aan alle gelijke aandacht te schenken; bovendien zullen vanzelfsprekend meerdere woorden van minder belang zijn voor ons onderwerp; om deze redenen zal slechts 
een gedeelte van de bij Martialis voorkomende deminutiva hier nader besproken worden en wel allereerst die deminutiva, welke vóór Martialis in het geheel niet voorkomen (GENUS A); vervolgens diegene, die we vóór Martialis wel aantreffen in proza-literatuur, maar die we bij Martialis voor het eerst gebruikt zien in poëzie, zodat ze ofwel door Martialis zelf, ofwel pas in zijn dagen in de poëzie binnengebracht schijnen te zijn (GENUS B.) ${ }^{7}$ )

\section{GENUS A.}

botellus: dem. v. botulus. Martialis, die deze woorden beide twee maal heeft, gebruikt ze zonder enig onderscheid in betekenis; misschien is het van belang, dat botellus alleen voorkomt als verseinde, terwijl het XI 31,13 in dienst schijnt te staan van een woordspeling: boletos imitatur et botellos.

bucella: dem. v. bucca, welk woord zelf reeds expressief-familiair is. Bij Martialis (VI 75, 3) betekent het „'n stukje, 'n hapje."

galericulum: dem v. galerum. Het grondwoord komt voor bij Juv. en Suet., het deminutivum bij Mart. en Suet. Bij Martialis schijnt het deminutivum gelijk te zijn aan het grondwoord (volgens Th. LL s.v.: ,i.q. galerum").

lecticariola: dem. v. lecticaria. Het deminutivum komt buiten Mart. XII 58, 8 nergens meer voor. Het is wel door Martialis zelf gevormd bij wijze van woordspeling met ancillariolus in het voorafgaande vers. Hierbij heeft Martialis dan meer gelet op de overeenkomst in klank dan op de goede afleiding van het woord. Hij immers, die ancillas bemint, heet ancillarius, of dem. ancill-ari-olus. $\mathrm{Zij}$, die lecticarios bemint, zou dus moeten heten lecticariaria, of dem. lecticari-ari-ola. Ter vermijding van de aldus optredende cacophonie en omwille van het metrum schrijft Martialis echter lecticariola.

panariolum: dem. v. panarium. Het deminutivum komt alleen voor bij Martialis (V 49,10) en dan nog wel, volgens STEPHANI, alleen om metrische redenen. Mij lijkt echter de deminutieve betekenis duidelijk aanwezig te zijn.

sestertiolum: dem. v. sestertium. Het grondwoord heeft Martialis vaker, maar steeds in de pluralis; het deminutivum (singularis) alleen I 58, 5 in de betekenis van ,een aardig sommetje."

7) Hierbij ga ik uit van het onderzoek, door STEPHANI ten aanzien van de "nova" ingesteld. Van hem is de indeling in Genus A en B. 
thermulae: dem. v. thermae. Het grondwoord lezen we bij Martialis 25 maal; het deminutivum, dat buiten Martialis nergens voorkomt, alleen VI 42, 1, waar sprake is van de door Statius om hun grootte en schoonheid geroemde clara Claudii Etrusci balnea; de beschrijving, die Martialis ervan geeft, duidt inderdaad op een prachtig gebouw. De eigenlijke deminutieve betekenis ontbreekt dus; misschien is alleen het metrum hier van beslissende betekenis geweest (STEPHANI).

togatulus: dem. v. togatus; Het grondwoord heeft Martialis 13 maal, o.a. in een ontlening aan Vergilius (Romanos rerum dominos gentemque togatam: Verg. I 282; Mart. XIV 124, 1); de gevoelswaarde van dit woord (Romeinse trots!) is Martialis dus wel bekend; de betekenis van het deminutivum, dat alleen bij onze dichter voorkomt, (XI 24, 11; X 74, 3), zal Martialis dan ook duidelijk voor ogen gestaan hebben: „'n mannetje in toga, cliënt."

umbella: dem. v. umbra. Umbella, dat ook nog voorkomt bij Juv., heeft Martialis alleen XIV 28 (lemma), waar in het gedichtje zelf umbraculum staat, en XI 73, 6. De aanwezigheid van de deminutieve betekenis is op beide plaatsen mogelijk, maar niet vereist.

Samenvattend kunnen we zeggen, dat de nova van Genus A in het algemeen zeker bijdragen tot de verhoging van het populaire element in Martialis' taal. Op de eerste plaats hebben de genoemde woorden practisch alle betrekking op het dagelijkse leven; verder zijn er meerdere, waarbij Martialis zeker niet gedacht heeft aan een kleinheid; in de omgangstaal is deze strikt deminutieve betekenis vaak verdwenen; enkele zijn gekenmerkt door hun expressiviteit en affectiviteit; tenslotte konden we opmerken, dat Martialis sommige deminutiva hoofdzakelijk gebruikt omwille van een woordspeling of om redenen van metrische aard, dus niet om het deminutivum als zodanig.

\section{GENUS B.}

alicula: naam van een klein kledingstuk; hiernaast staat alica = "speltbrei", welk woord o.a. voorkomt in XIII 6, 1, waar sprake is van een geschenk voor een arme. Beide woorden hebben in betekenis niets met elkaar uitstaande, maar toch plaatst Martialis ze tegenover elkaar in XII 81, 2. 3:

mittebat Umber aliculam mihi pauper; nunc mittit alicam: factus est enim dives. 
Een aardige, sarcastisch bedoelde woordspelling, waarbij Martialis suggereert, dat alica iets groots, alicula iets (gelijksoortig) kleins is. In ieder geval blijkt, dat Martialis alicula zeer scherp als deminutivum voelt. Alicula komt ook voor bij Petronius.

ancillariolus: dem. v. ancillarius; volgens STEPHANI s.v. is dit deminutivum, - het komt ook nog voor bij Sen. benef. -, door Martialis gebruikt omwille van het metrum.

cenula: dem v. cena. Het deminutivum komt, behalve bij Martialis, nog voor bij Varro Men., Cic. Tusc. en epist., Petron., Juv., Suet., Claud., posteriores. Reeds hieruit blijkt het populaire karakter van dit woord. Maar er is meer: V 78, 22 staat parva est cenula, en VII 51, 12 cenula parva; ter versterking van de deminutieve betekenis is dus blijkbaar de bijvoeging van een adjectivum gewenst; ook in X 48,13 staat cenula, maar blijkens de opsomming van de spijzen (haedus, pullus, perna, faba, poma, etc.) is deze maaltijd niet zo klein!

craticula: dem. v. cratis (= „rooster”). Komt, buiten Martialis, nog voor bij Cat. agr., Petron., posteriores. Martialis heeft het alleen XIV 221, in lemmate en vs. 1 , in welk vers ook nog het deminutivum ofella staat.

fidiculae: dem. v. fides. Bij Martialis (V 51, 6) heeft het de betekenis "folterkoord", zoals ook bij Val. Max., Sen. dial., Suet. Een strikt deminutieve betekenis behoeft $\mathrm{m}$.i. niet aangenomen te worden.

glandulae: dem. v. glandium. Volgens de ThLL s.v. is het deminutivum bij Martialis ,i.q. glandium" en draagt het dus geen speciale deminutieve betekenis. Martialis heeft dit woord in III 82, 20 en VII 20, 4: apri glandulae = "het halsstuk van een zwijn". Dit gold bij de Romeinen voor een zeer fijn gerecht; misschien is het wel deze nuance, die door het deminutivum wordt uitgedrukt. (Celsus heeft dit woord ook, maar dan als medische term, waarschijnlijk = ,amandelen".)

loculus-locellus: dem. v. locus. Het deminutivum wordt meestal in de pluralis-vorm gebezigd en betekent: ,geldkistje (met meerdere vakjes".) Martialis heeft loculi 4, locellus, dat volgens STEPHANI om metrische redenen gebruikt wordt, 2 maal. De verdeling van deze woorden is echter opvallend: XIV 12 draagt als titel loculi eburnei, en handelt over het geschenk voor een rijke; in het gedichtje zelf staat eveneens loculi. XIV 13 heeft in lemmate loculi lignei, en betreft dus het geschenk voor een arme; in het gedichtje echter lezen we tot twee maal toe locel- 
lus (singularis!). Ik vraag me af, of hier werkelijk alleen het metrum van belang is; het is toch zeer wel mogelijk, dat Martialis door het schrijven van de vormen loculi en locellus het verschil in kwaliteit en vorm van de beide geschenken heeft willen aanduiden; dat desniettegenstaande de titels van beide gedichtjes alleen de vorm loculi bevatten, behoeft geen bezwaar te zijn, daar hierdoor duidelijk wordt aangegeven, dat deze epigrammen paarsgewijze met elkaar verbonden zijn, en omdat de toegevoegde attributen eburnei-lignei duidelijk het "rijke" resp. het ,arme" karakter van het geschenk aanduiden.

Loculi komt ook reeds voor bij Hor. sat. en ep.; locellus echter staat bij Martialis voor het eerst in poëzie: was dit laatste misschien meer prozaïsch, of wellicht meer populair?

mannulus: dem. v. mannus. We lezen het bij Martialis alleen XII 24, 8, waar het inderdaad een deminutieve betekenis heeft.

ofella: dem. v. offa. Het grondwoord is weliswaar oud, maar volgens DEL draagt het een familiair karakter. Martialis gebruikt ofella inderdaad als deminutivum, maar het staat bij hem, zoals ook STEPHANI reeds opmerkt, steeds als verseinde; ook Juv. 11, 143 en Anthol. 206, 3 gebruiken het als verseinde. Het gebruik van het deminutivum wordt dus blijkbaar mede door het metrum bepaald.

regulus: dem. v. rex. Martialis heeft het in III 16, 1 sutorum regule, cerdo; een opvallende opeenvolging van drie woorden, die in hun vorming 't populaire karakter verraden (sutor: suffix-tor, ( - tor veroorzaakt het populaire karakter natuurlijk niet, maar kan het wél accentueren); regulus: dem.; cerdo: mannelijke beroepsnaam op -o, genit. -onis) Regulus heeft op genoemde plaats een minachtende gevoelswaarde en is dus affectief gekleurd.

tegeticula: dem. v. teges. Behalve Martialis, die IX 92, 3 schrijft vilis tegeticula ,een goedkoop slaapmatje", hebben ook Varro r.r. en Col. dit deminutivum.

vernula: dem. v. verna. Het grondwoord is een populaire vorming op - $a$ (DEL s.v.). Het deminutivum, dat pas opkomt in de Keizertijd, (Sen., Mart., Juv., Prud., etc.), heeft bij Martialis steeds een verkleinende en affectieve betekenis; zo stelt hij in $\mathrm{V} 37,20$ vernula verachtend tegenover coniunx, en plaatst hij vernula in XIV 54, 1 in een populaire omgeving (plorator, garrulus). V18, 4 libellos vernulas spreekt voor zich zelf.

De bovenstaande woorden rekent STEPHANI tot Genus B. 
Ik zou echter ook de drie volgende hieraan willen toevoegen om redenen, die ik bij elk woord afzonderlijk vermeld:

coliculus: dem. v. colis (caulis). De ThLL geeft s.v. cauliculus: „saepissime legitur coliculus, ex. gr. Cato agr., Varro rust., Vitr., Cels., Colum., Petron., Mart., posteriores." Onder de genoemde auteurs is Martialis dus de eerste, die het blijkbaar zeer prozaïsche woord in deze schrijfwijze in poëzie gebruikt. De betekenis kan volgens de ThLL zijn: 1) „parvus frutex herbarum vel arborum"; dus met deminutieve kracht. Aldus bezigt Martialis het nergens. 2) ,i.q. brassica”. Zo komt het voor bij Petron., Mart., Bibac. carm., Porph. Hor. sat. e.a. De betekenis is dus bij Martialis gewoon „kool” zonder deminutieve nuance. Opvallend is, dat XIII 17 coliculus in de titel heeft maar caulis in het gedichtje zelf: dus, zoals we reeds enkele malen zagen, ook hier weer het meer populaire woord als titel, waar het gedichtje zelf dit woord niet bevat.

matella: dem. v. matula, „pot de chambre”. In deze betekenis vinden we het deminutivum bij Sen. benef., Petron., Mart., Juv. en (misschien) bij Varro Men. Voor het populaire karakter van het woord pleiten zowel zijn betekenis als enkele auteurs, waarbij het gevonden wordt, als ook wellicht het feit, dat een der Martialis-plaatsen (X 11, 3) doet herinneren aan een Romeins spreekwoord (vgl. Otto, Sprichw. p. 215).

testiculi: dem. v. testes (fr. testicule). Zowel het grondwoord als het deminutivum vinden we eenmaal bij Martialis (XIII 63,2 ; resp. III 24, 5). Testiculi lezen we voorts bij Cels. en Juv. De onvolledigheid van de ThLL verhinderde mij na te gaan, of het woord nog bij andere auteurs gevonden wordt, maar voorzover ik kon nagaan. komt de pluralis-vorm bij Martialis voor het eerst in poëzie voor. Persius heeft wel de (overigens, naar mijn mening, niet voorkomende) singularis-vorm testiculus.

Uit bovenstaande gegevens blijkt dus, dat, vergeleken met de woorden van Genus A, deze tweede groep enigszins in waarde gedaald is voor mijn onderzoek. We ontmoeten immers meer gevallen, waar de deminutieve betekenis nog duidelijk aanwezig is, terwijl we minder vaak een sterke affectieve nuance aantreffen. Maar hiertegenover staan toch nog verschillende plaatsen, waar de deminutieve betekenis verzwakt of zelfs geheel verdwenen blijkt te zijn, terwijl ook de populaire inslag zeker niet ontbreekt. Het is echter duidelijk, dat we niet, zoals STEPHANI doet, ons oordeel moeten vellen over een gehele 
groep van woorden, maar dat we uiteindelijk toch gedwongen zijn, geval voor geval afzonderlijk na te gaan.

Nog een enkele opmerking: het is bekend, dat de omgangstaal een bijzondere voorliefde heeft voor woorden, die over een groter klankvolume beschikken, welk groter volume o.a. bereikt kan worden door de toevoeging van het deminutiefsuffix. In dit verband is het opmerkelijk, dat het gemiddeld aantal lettergrepen, waaruit de woorden van Genus $\mathrm{A}$ bestaan, 4,2 bedraagt, waarnaast we voor Genus $B$ een gemiddelde van 3,7 vinden, hetgeen in overeenstemming is met het iets meer populaire karakter van Genus A.

\section{d. DEMINUTIVA, DIE MARTIALIS MET CATULLUS GE- MEENSCHAPPELIJK HEEFT.}

Van de overige deminutiva verdienen natuurlijk speciale aandacht die woorden, welke Martialis met zijn grote voorbeeld Catullus gemeenschappelijk heeft. STEPHANI wijst erop, dat Martialis van de 27 deminutiva, die Catullus als eerste van de Romeinse dichters gebruikte, de volgende heeft overgenomen: codicillus, lapillus, libellus, mentula, sacculus, versiculus, albulus en gemellus; verder heeft hij gemeenschappelijk met $\mathrm{Ca}$ tullus:catulus, flagellum, lectulus, munusculum, ocellus, papilla, puella, tabella, aureolus, bellus, misellus, parvulus, pusillus, vetulus. De hier genoemde adjectiva kwamen reeds eerder ter sprake. Van de substantiva vragen de volgende onze aandacht:

flagelhum: dem. v. flagrum. Het grondwoord, slechts zelden voorkomend, is reeds vroeg vervangen door zijn deminutivum, dat niet alleen bij de meer populaire auteurs, maar ook bij epici en in het hogere proza de voorkeur geniet, en overgeleverd is in de Romaanse talen (prov. flagel, fr. fléau). Bij Martialis lezen we flagrum 2 maal, flagellum, zonder enig verschil in betekenis, 6 maal. Van een populair karakter behoeft hier dus niet per se sprake te zijn.

Volgens FRIEDLAENDER a.1. zou in XIV 55 (titel en vers 1) de deminutieve betekenis wél aanwezig zijn; hij veronderstelt, dat dit gedichtje betrekking heeft op een speelgoedzweepje, en gezien moet worden in verbinding met XIV 54 (crepitacillum = „rammelaar"). Dit is m.i. echter zeer onzeker, op de eerste plaats, omdat flagellum op geen der overige plaatsen een deminutieve betekenis draagt; voorts omdat de juiste volgorde van deze gedichtjes niet vaststaat, terwijl tenslotte in 
het bedoelde epigram zelf niets wijst op de juistheid van FRIEDLAENDERS opvatting.

lapillus: dem. v. lapis. Volgens SCHNEIDER zou Martialis in plaats van de voor zijn metra ongeschikte dat. abl. plur. lapidibus $(,,,$,$) de deminutief-vorm lapillis gebruikt heb-$ ben, ook daar, waar dit voor de betekenis niet direct noodzakelijk is. Ik zou hierbij willen opmerken, dat Martialis hiernaast ook andere casus van het deminutivum gebruikt (lapilli, lapillos), en dat m.i. overal een duidelijk verschil in betekenis aanwezig is tussen grondwoord en deminutivum (lapis duidt bij Martialis meestal een „mijlpaal” of een monument aan; lapillus nooit!) Ook de affectieve nuance ontbreekt. De eenzijdige verklaring van SCHNEIDER is dus wel niet geheel juist.

libellus: dem. v. liber. Het grote belang van dit woord blijkt reeds uit het feit, dat we libellus 115 , liber 58 maal lezen bij Martialis. Het is moeilijk een vaste lijn te ontdekken in het gebruik van deze woorden. Er zijn plaatsen, waaruit men kan opmaken, dat het verschil in betekenis Martialis duidelijk voor ogen staat. Zo XI 1, 5 libros non legit ille, sed libellos. Zie o.a. ook X 1,1 en 2 . Het deminutivum is ook volkomen verantwoord in II 6, 10 tam macer libellus. Hiernaast staan echter gevallen, waar Martialis zijn keuze niet zo nauwkeurig bepaalt; zo noemt hij zijn derde boek in III 100, 4 liber, maar in andere epigrammen (b.v. 97) libellus; in VIII 1, 1 en 3 noemt hij hetzelfde boek liber én libellus; in XI 16, 7 staat nostri libelli, maar in vers 9 meum librum. Is dit zuiver willekeur, of metrische dwang of variatio? Of is de verkleinende betekenis van libellus bij Martialis niet steeds duidelijk aanwezig geweest en zou dit op enkele plaatsen, waar hij de deminutieve betekenis nodig had, geleid hebben tot de omschrijving parve liber (I 3, 2; III 5, 2)? Soms is er van een deminutieve betekenis geen sprake, zo in III 68, 11, waar Martialis zegt: longum iam lassa libellum ponebas, en XI 108, 1 tam longo . . . . libello. Ik vraag mij dan ook af, of wellicht niet een andere factor hier van belang is: zou het niet mogelijk zijn, dat in Martialis' dagen het deminutivum libellus, ongeacht de lengte van het boek, de geijkte term was voor elk oeuvre van het literaire genre, waarin Martialis werkzaam was en is niet juist de vorm liber, en niet het deminutivum, hier opmerkelijk?

munusculum: dem. v. munus. Het deminutivum komt bij Martialis slechts 4 maal, het grondwoord daarentegen zeer vaak voor. Op enkele plaatsen, waar Martialis de verkleinende be- 
tekenis wil gebruiken, heeft hij de omschrijving parvum munus (IV 88, 1; VII 17, 9; IX 53,1). Dit zou reeds het vermoeden kunnen wekken, dat het deminutivum voor Martialis' gevoel blijkbaar niet meer over voldoende kracht beschikte; hierbij komt echter nog, dat op drie van de vier plaatsen (V 84, 7; VII 49,1 ; VII 80,5$)$ munuscula versterkt is door het adjectivum parva, terwijl we op de vierde plaats, IX 54, 11, lezen: parvae munuscula chortis, waar parvus wel niet direct bij munuscula hoort, maar er toch wel indirect mee verbonden is. (chors is een „terme rurale"!)

Van de overige woorden valt slechts weinig te zeggen; wel hebben ze alle betrekking op het dagelijkse leven, maar over het algemeen is de deminutieve betekenis, soms zelfs zeer sterk, aanwezig; de affectieve nuance ontbreekt niet (b.v. bij ocellus, versiculus), terwijl de erotische sfeer ook menigmaal door deze deminutiva versterkt wordt (o.a. papilla, puella). Samenvattend moeten we echter concluderen, dat de invloed van de omgangstaal bij deze groep geringer is dan bij de voorafgaande groepen $\left.{ }^{8}\right)$.

\section{e. DE OVERIGE DEMINUTIVA.}

Bij de deminutiva, die in het voorafgaande nog geen bespreking vonden, zijn er meerdere, die voor ons onderzoek geen speciale waarde bezitten; het zijn: anulus, articulus, circulus, crepitacillum (alleen in lemmate), litterula, marculus, maxilla, palliolum, pastillus, patella, porcellus, scripulum, scutula, securicula, servulus, sextula, sparulus, sportula, togula, turricula, urceolus. Hier is de deminutieve betekenis vrijwel steeds zeer duidelijk aanwezig; van een affectieve nuance is in mindere mate sprake.

De volgende woorden vereisen echter nog een nadere toelichting:

agellus: dem. v. ager. Martialis gebruikt het elf maal in normale omstandigheden, doch op één plaats (X 92,13) lezen we parvuli agelli.

ampulla: dem. v. amphora. Het deminutivum leefde voort in de gesproken taal, het grondwoord niet. In de betekenis van vasculum potorium komt het deminutivum voor bij Suet. Dom.,

\footnotetext{
8) Het gemiddelde aantal lettergrepen van deze „Catulliana" bedraagt 3,6, een miniem en practisch te verwaarlozen verschil met de nova van genus B; opmerkelijk is wel, dat we bij de Catulliana geen enkel woord van meer dan vier lettergrepen aantreffen.
} 
Porph. Hor. sat., en Mart. (XIV 110 lemma; VI 35, 4); voor vasculum olearium bezigen het Plaut., Cic. fin., Petron., Mart. (III 82, 26). Wijzen deze gegevens misschien op een meer populair karakter van het deminutivum?

ancilla: dem. v. ancula. Aan de ThLL ontleen ik het volgende (s.v. ancilla): „vox inde a Livio Andronico usque ad infimam aetatem in usu fuit, scaenicae, satiricae (Lucil. Varro Hor. Juv.), amatoriae poesi (Cat. Hor. Tib. Ov. Mart.) familiarissima. abhorret ab epico sermone, in quo famula praefertur". Het is dus een woord, dat voor de hogere dichtertaal onaanvaardbaar was, maar wel gebruikt kon worden door dichters van het lyrisch-elegische en satyrische genre. Uitgesproken populair behoeft het daarom nog niet te zijn.

arcula: dem. v. arca. Martialis heeft het deminutivum in II 46, 4 sic micat innumeris arcula synthesibus. Hieruit blijkt dus, dat hier niet een kist van klein formaat bedoeld kan zijn; door de volgende verzen wordt dit ten overvloede bevestigd. Opvallend is, dat het grondwoord arca bij Martialis steeds betekent "geldkist", zodat bij hem het deminutivum duidt op een voorwerp van groter formaat dan het grondwoord!

armilla: „armband" Dit woord verschijnt tot Phaedrus steeds in de pluralisvorm; Pnaedrus bezigt voor het eerst de singularis, die we na hem ook vinden bij Petron., Plin. nat., Mart. (XI 21, 7), Suet., Vulg. Mogen we hieruit concluderen, dat de singularis van dit woord alleen in meer populaire of familiaire taal voorkwam, of is het onderscheid slechts van chronologische aard?

asellus: dem. v. asinus. Het grondwoord komt niet voor bij Martialis, het deminutivum is bij hem echter practisch gelijk aan asinus (VI 39, 16; XII 36, 13). DEL geeft voor asellus (s.v. asinus): „diminutif familier, de caractère populaire, passé dans les 1 . romanes M. L. 701 et aussi dans les 1 . germaniques et de là en slave". Het deminutivum komt voor bij Varro rust., Cic. Att. en rep., Verg. georg., Copa, Prop., Priap., Ov. fast., Phaedr., Mart., Juv., Val. Max. AXELSON p. 44v. vermoedt, dat asinus een niet-poëtische klank had, om welke reden de dichters wellicht de voorkeur gaven aan asellus. Men zou hierbij kunnen opmerken, dat de dichters, die het deminutivum gebruiken, in het algemeen gesproken zeker niet de exponenten zijn van de meer verheven stijl; we vinden het wel bij Vergilius, maar blijkbaar niet in de Aeneis!; hiertegenover staat echter, dat asinus evenmin voorkomt in de Aeneis; ook de dichters van de minder ver- 
heven genres gebruiken asinus zelden of in het geheel niet. De eerste vraag, die we ons moeten stellen, is dus niet, of asellus meer of minder populair was dan asinus. De toestand is wellicht zo, dat asinus krachtens zijn betekenis te grof is, en dat het minder fijne woord „ezel” door de poëzie vermeden werd; om deze reden vluchtte men in het deminutivum (euphemisme!). Uit dit alles volgt volstrekt niet, dat asellus een populair woord geweest is. Het is dus juist, dat DEL (z.b.) het woord asellus niet zonder meer "populaire” noemt, maar zich voorzichtiger uitdrukt door te spreken van een "caractère populaire". Het gaat echter niet aan om, gelijk AXELSON p. 45 doet, het populaire karakter van asellus in twijfel te trekken, alleen op grond van de veronderstelling, dat de afgeleide vormen in de Rom. talen slechts op asinus, en niet op het deminutivum teruggaan; een veronderstelling, die blijkens de bovenstaande aanhaling uit DEL bovendien onjuist is.

aureolus: dem. v. aureus. De deminutief-vorm = aureus vel auratus vinden we bij Plaut., Lucil., Catull., Petron., Vulg., post.; = aureum colorem habens bij Varro rust. en in de Culex. Wijst dit alles niet reeds op het meer populaire karakter van het deminutivum? Martialis schijnt de enige auteur te zijn, die dit woord substantivisch gebruikt (sc. nummus). Hierbij staat dan, naar mijn mening, de strikt deminutieve betekenis niet op de voorgrond.

auricula: dem. v. auris. Het deminutivum vervangt in de populaire taal auris en is dan ook overgegaan in de Romaanse talen (fr. oreille). Ook bij Martialis heeft auricula zijn deminutieve betekenis blijkbaar verloren. Men vergelijke

III 28, 2 garris in auriculam

met $\mathrm{V} 61,3$ garris in aurem,

en XIV 142 Si recitaturus dedero tibi forte libellum

hos focale tuas adserat auriculas.

met IV 41 Quid recitaturus circumdas vellera collo?

Conveniunt nostris auribus ista magis.

In V 77, 2 (ferre oleum ....in auricula) hebben we waarschijnlijk te doen met een spreekwoord, waar een dergelijk populair deminutivum zeker op zijn plaats is.

capella: dem. v. capra. De affectieve nuance, die dit (poëtische) deminutivum bij andere auteurs vaak bezit, ontbreekt practisch geheel in VII 31,3 et illud oleas quod viri capellarum. Het deminutivum lezen we voorts bij Hor. ep., Ov. ars, Colum., Varro rust., Verg. catal., Juv. De dichters geven in tegenstelling 
met de prozaïsten, aan het deminutivum de voorkeur boven het grondwoord. Zie AXELSON p. 44.

catellus: dem. v. catulus. Bij Martialis $(I 83,1)$ is èn de deminutieve betekenis èn de affectieve nuance sterk aanwezig. Overigens komt dit deminutivum proprie i.q. catulus alleen voor bij Plaut., Varro Men., Cic. div. (1 maal), Mart., en Juv., dus overwegend bij meer populaire auteurs.

catella: dem. v. catula. Het deminutivum is bij Martialis steeds affectief gekleurd; opvallend is echter, dat hij het deminutivum soms versterkt door toevoeging van parva (XIV 198, 1) of exigua (VII 87, 3). Volgens de ThLL komt het deminutivum „proprie i.q. catula" voor bij Petron., Mart., Juv. In Martialis I 109, 5 is sprake van een catella met de populaire naam Issa (<Ipsa).

cistella: dem. v. cistula. Komt buiten Martialis XIII 36 (lemma) slechts voor bij Plaut. en Ter.

cistula: dem. v. cista. De deminutieve betekenis is in Martialis IV 46, 13 zeer zeker aanwezig. Het grondwoord komt niet voor bij Martialis. Het deminutivum vinden we voorts nog bij Plaut., Apul. met., posteriores.

pellicula: dem. v. pellis. Het deminutivum lezen we bij Martialis alleen in III 16, 6 nunc in pellicula, cerdo, tenere tua, waar we weer te doen hebben met een spreekwoordelijke uitdrukking. Overigens heeft Martialis steeds pellis.

$\mathrm{Al}$ was bij de laatst-behandelde woorden het populaire karakter niet steeds even duidelijk aanwezig, het is toch evident, dat ze alle min of meer bijdragen tot de verhoging van de populaire sfeer van Martialis' gedichten.

Alvorens dit hoofdstuk te besluiten wil ik nog even de aandacht vestigen op twee woorden, die in dit verband vermelding verdienen: het eerste is ligula „lepel”; zo althans is in de „betere stand" de uitspraak van dit woord; de minder ontwikkelden zeiden lingula (zie Mart. XIV 120); men verwarde dit woord met het deminutivum van lingua, óf men bracht het in verband met het verbum lingere. Martialis geeft de voorkeur aan ligula (op meerdere plaatsen!), dus niet aan de populaire schrijfwijze. (lingula = schoenveter, heeft Mart. II 29,7).

Dan het woord vitellus ,geel van het ei": dit woord is phonetisch identiek met vitellus, dem. v. vitulus, maar de semantische relatie is niet duidelijk; om deze reden kunnen we het hier beter buiten beschouwing laten.

De gegevens van deze paragraaf overziende, kunnen we concluderen, dat Martialis, afgezien van de vele gevallen, waar de 
verkleinende betekenis en/of de al dan niet sterke subjectieve nuance, vaak in erotische sfeer, duidelijk aanwezig zijn, toch ook menigmaal gebruik maakt van deminutiva zonder de oorspronkelijke kracht ervan te benutten. Op andere plaatsen weer oordeelt hij het dienstig de - blijkbaar verzwakte - waarde van de deminutief-vorm te versterken, o.a. door toevoeging van een woord als parvus, of door aan een substantivum in de deminutiefvorm een overeenkomstig adjectivum toe te voegen. ${ }^{9}$ ) Voorts bleek uit de vermelde gegevens ook meerdere malen, dat een bepaald woord zeker ontleend is aan de meer familiaire of populaire omgangstaal. Ook al geldt dit niet voor de gehele, in deze paragraaf behandelde groep, dan is het toch duidelijk, dat een belangrijk percentage het populaire coloriet van Martialis' oeuvre verhoogt.

Op Martialis is evenzeer van toepassing, wat DE LABRIOLLE p. 287 zegt over Plautus: „Plaute a un grand nombre de diminutifs qu'il-semble avoir empruntés tant à la langue familière qu'à sa propre imagination". Overigens is ook hierin Martialis een echt kind van zijn tijd, omdat juist in de Keizertijd het gebruik van de deminutiva steeds groter, en bij sommige auteurs zelfs tot een ware manie wordt.

Vergelijken we Martialis met Catullus, dan blijkt, dat de laatste, bij wie eveneens zeer vele deminutiva voorkomen, ze voornamelijk gebruikt om hun expressieve kracht, dat hij er dus iets mee dóet. De conclusie van DE LABRIOLLE luidt immers aldus p. 287: „Mais l'essentiel est qu'on s'aperçoive de la valeur pittoresque que le diminutif a prise très ordinairement chez Catulle et des ressources que le savant poète, doctus Catullus, y a trouvées". Op Martialis is dit slechts ten dele van toepassing, tenzij men ten aanzien van onze dichter onder de "valeur pittoresque" óók zou willen verstaan het schilderen van een meer populaire sfeer.

Het feit, dat Martialis van de deminutiva een zo veelvuldig gebruik maakt, krijgt een speciale betekenis in het licht van het onderzoek van AXELSON (p. $38 \mathrm{vv}$.), die tot de volgende conclusie komt p. 44: „Dass die Dichtung mit Ausnahme der niederen Gattungen, von augusteischer Zeit an trotzdem den Deminutivbildungen derart ablehnend gegenübersteht, wie es nach dem oben Dargelegten der Fall ist, zeigt besonders deut-

9) P. DE LABRIOLLE p. 278 wijst erop, dat de verbinding van een adjectivisch deminutivum met een substantivisch dem. vaker voorkomt, zowel bij Griekse als bij Latịnse auteurs (o.a. Catullus). 
lich, dass ihr die Hände hier durch eine Stilregel besonderer Strenge gebunden waren. Je weiter sie sich von der Sphäre des Alltagsleben entfernt, desto stärker macht sich diese Regel geltend". Omgekeerd zou men hieruit dan de conclusie kunnen trekken, dat een dichter, die de deminutiva opvallend veel bezigt, (en dit is zeker bij Martialis het geval!) dus ook nauwer met de gewone omgangstaal verbonden is.

\section{§ 3. HET GEBRUIK VAN SYNONIEMEN}

Reeds in de inleiding kwam deze kwestie even ter sprake, daar namelijk, waar ik erop wees, dat het gebruik van Griekse woorden in plaats van Latijnse bepaald kan worden door redenen van metrische aard; ik gaf daar als voorbeeld het - in de omgangstaal gebruikelijke - moechus, dat (aldus SCHNEIDER) door Martialis in zijn dactylische verzen gebezigd wordt in plaats van het dan ongeschikte concubinus. Bezien we dit voorbeeld $\mathrm{nu}$ in iets ruimer verband, dan vinden we het volgende: Martialis heeft concubinus zes maal (het vrouwelijke concubina nog eenmaal) in niet-dactylische verzen. Moechus lezen we 15 maal, maar niet uitsluitend in dactyli; dit laatste geldt ook voor moecha, dat we 14 maal aantreffen. Tenslotte mogen we dan nog vermelden dat adulter en adultera elk twee maal voorkomen, steeds in dactyli. Hieruit blijkt dus duidelijk, dat we niet, zoals SCHNEIDER deed, zonder meer mogen zeggen, dat het gebruik van deze synoniemen door het metrum bepaald wordt. Het feit immers, dat Martialis het (meest frequente!) moechus (moecha) ook in niet-dactylische verzen gebruikt, bewijst wel, dat dit woord - zoals gezegd, was dit met name in de omgangstaal gebruikelijk - de voorkeur geniet. Opmerkelijk is ook nog het volgende: in het epigram IX 2 lezen we in de verzen $1,3,5,9,11$ achtereenvolgens deze synoniemen: amica, adultera, domina, moecha en puella. Hier is dus wel zeer duidelijk een streven naar variatio aanwezig; dit stylistische principe, dat bij Martialis overigens een belangrijke rol speelt, valt als zodanig buiten mijn onderwerp en zal dan ook slechts, zoals in het bovenstaande voorbeeld, ter sprake komen, waar het gebruik van bepaalde omgangstaal-woorden er mede door bevorderd of beïnvloed kan zijn.

Intussen demonstreert het bovenstaande zeer duidelijk, dat we, bij de beoordeling van de door Martialis gebruikte synoniemen, niet een eenzijdige maatstaf mogen aanleggen, maar moeten rekening houden met andere verklarings-mogelijkheden 
(dus o.a. metrum, frequentie, variatio, sfeer van het gedicht), welke ofwel van geval tot geval kunnen verschillen, ofwel in combinatie aanwezig kunnen zijn. Tevens bood het bovenstaande geval $\mathrm{mij}$ een goede gelegenheid om de bedoeling van het thans volgende duidelijk te maken.

\section{a. Adiectiva}

Allereerst dan enige opmerkingen, betrekking hebbende op de adiectiva:

$$
\text { bellus en pulcher. }
$$

Het adiectivum bellus, dat reeds ter sprake kwam in de paragraaf, die handelde over de deminutiva, heeft, vergeleken met pulcher, een speciale affectieve kracht, reden waarom het laatste woord op den duur door bellus werd verdrongen; men denke b.v. aan het fr. beau. Bellus hoort thuis in de familiaire taal en hoeft dus niet per se vulgair te zijn, ook al gebruiken Petronius' liberti het in hun gesprekken zeven maal zo vaak als pulcher. We vinden het o.a. bij Catullus en Phaedrus, terwijl pulcher bij Vitruvius b.v. niet voorkomt. Martialis heeft bellus 18 maal en het adverbium belle 17 maal, terwijl we pulcher bij hem op 26, en het adv. pulchre op 4 plaatsen aantreffen. Opvallend is, dat bellus niet in choliamben voorkomt! Het gebruik van bellus, dat dus een kleine meerderheid vertoont t.o.v. pulcher, zullen we, behalve door invloed van Catullus, ook wel kunnen verklaren door de invloed van de omgangstaal; voor deze opvatting vinden we een sterke steun bij AXELSON, p. 35: „Auch z.B. bellus findet in der gehobenen Poesie einen äusserst spärlichen Gebrauch. Merkwürdig ist sein zweimaliges Vorkommen bei dem Puristen Tibull, da es im ganzen Ovid nur einmal (am. 1, 9, 6 bella puella, feste Formel, auch bei Lygd. 4, 52), bei Properz niemals begegnet (wie es in der Epik und den anderen höheren Gattungen selbstverständlich fehlt, nur dass Lukrez 4,1190 bellus und 1,643 das entsprechende Adverb hat). Voor Martialis bestaat er soms weinig of geen verschil tussen bellus en pulcher; men vergelijke b.v. II 87,1 (bellas puellas) met VI 16, 4 (pulchra puella).

\section{grandis-magnus.}

De conclusie van LöFSTEDT (Komm. Peregr. p. 72), dat magnus op den duur overwonnen is door grandis (getuige o.a. het feit, dat in de Peregr. Aeth. grandis in de meerderheid is; getuige ook de Romaanse talen) wordt zeker niet aangetast door NELSON's opvatting, dat grandis in Petronius' dagen nog een 
modewoord was in de gecultiveerde omgangstaal en pas later is afgezakt tot de volkstaal. In dit licht krijgt dan ook de toestand bij Martialis zijn betekenis, bij wie we naast \pm 150 plaatsen met magnus, 43 maal grandis vinden. Het oorspronkelijke betekenis-verschil tussen grandis en magnus begint reeds in de eerste eeuw na Chr. te vervagen. Ook Martialis biedt ons hiervan enige duidelijke voorbeelden. Men leze b.v. X 79, 9: grandis ut exiguam bos ranam ruperat olim (waar dus sprake is van lichamelijke grootte), naast II 44, 10: $O$, grande ingenium mei sodalis! (waar grandis een meer abstracte betekenis heeft). Duidelijk is ook VIII 50,9: grandia pollicitus, quanto maiora dedisti!, waar we in een en hetzelfde vers grandis lezen én de comparativus van magnus!

Hoewel de vervaging, en zelfs de opheffing van het verschil in betekenis van beide woorden bij Martialis duidelijk waarneembaar is, is grandis, waarvan de frequentie op zich belangrijk genoemd kan worden, bij hem nog niet direct een gevaarlijke concurrent van magnus. Martialis houdt zich dus aan het algemeen gangbare spraakgebruik van zijn dagen en ontleent hier (aangenomen, dat NELSON's opvatting juist is) eerder aan de omgangstaal van de hogere dan van de lagere standen.

\section{imus-infimus.}

Uit 't onderzoek van AXELSON p. 33 v. blijkt, dat infimus het woord is, dat met name in het klassieke proza gebezigd wordt, terwijl imus niet alleen in de omgangstaal, maar ook bij de dichters de voorkeur geniet: „sie (sc. de Dichters) haben sich in diesem Punkt wie in vielen anderen einfach an die lebendige Sprache angeschlossen, ohne sich um die Tendenzen der klassischen Proza zu kümmern". Hierbij zal het feit, dat infimus in het algemeen weinig geschikt is voor 't metrum (in het bijzonder voor de dactyli!), terwijl imus dit wél is, zeker van belang zijn. Martialis nu gebruikt infimus slechts 1 maal, en wel in de brief, die aan het eerste boek voorafgaat, dus in proza! In zijn epigrammen daarentegen bezigt hij (I 5,10 (dact.) ; VII 17, 5 (hendec.) ; X 80, 3 (dact.) imus; het betreft hier gedichtjes, die meer verheven van inhoud zijn en vrijwel geen andere popularismen bevatten. Mij lijkt dan ook, dat we, gezien deze gegevens, het gebruik van imus bij Martialis niet op de eerste plaats als een popularisme, maar wel als een poeticisme moeten beschouwen. 


\section{lassus-fessus.}

Volgens BAEHRENS komt fessus, dat terugontwikkeld is uit defessus < * de-fassus, pas voor sedert Varro; in de Romaanse talen is het niet overgeleverd; hier vinden we alleen lassus. Voorts deelt BAEHRENS ons mede, dat Horatius in zijn Oden aan fessus, en in zijn Satiren aan lassus de voorkeur geeft. Ook Petronius wijst duidelijk in dezelfde richting. We zullen dan ook de omstandigheid, dat Martialis lassus 23 maal bezigt ${ }^{10}$ ), fessus daarentegen slechts 5 maal, in onze conclusie aan het eind van dit onderdeel moeten betrekken. Dat lassus ook in de hogere poëzie zeker niet ongebruikelijk is, behoeft aan het populair karakter van dit woord geen afbreuk te doen, zoals wordt aangetoond door AXELSON p. 29, die, ondanks het voorkomen van lassus bij dichters als Verg., Hor., Ov., toch het „recht stark vulgäres Gepräge" van dit woord niet betwijfelt!

\section{b. Substantiva. \\ basium-osculum. \\ (basiare-osculari).}

M. HAUPT spreekt, opusc. II p. 106, als zijn vermoeden uit, dat basium en basiare woorden zijn van niet-Latijnse oorsprong, maar dat zij pas later in het Latijn zijn opgenomen; in de literatuur zou basium zijn binnengebracht door Catullus. We kunnen wel aannemen, dat basium/basiare in de post-klassieke periode, en met name in het laat-Latijn, de voorkeur hebben gehad in de volksmond. Hierop wijst het voorkomen bij auteurs als Phaedrus, Petronius, Juvenalis, Apuleius en Fronto, én de overgang van beide woorden in de Romaanse talen ${ }^{11}$ ). Bij Martialis vinden we de volgende verdeling:

frequentie:

frequentie:

\begin{tabular}{lllr}
\hline basium & 29 & osculum & 10 \\
basiare & 20 & osculari & - \\
& & perosculari & 1
\end{tabular}

Het simplex osculari komt dus in het geheel niet, het compositum perosculari slechts eenmaal voor. Basium/basiare zijn ver in de meerderheid en worden bovendien nog gesteund door basiatio (2 maal) en basiator (4 maal). SCHNEIDER is van me-

10) AXELSON p. 29 geeft het getal 22 op; misschien laat hij II pr. 15 buiten beschouwing, omdat het hier niet een plaats in een epigram, maar in een inleidende brief betreft.

11) vgl. AXELSON p. 35. 
ning, dat in het onderhavige geval de verdeling van de beide synoniemen over Martialis' werk door het metrum bepaald wordt, maar daar we elk van deze synoniemen in verschillende metra aantreffen, komt dit mij onwaarschijnlijk voor.

Interessant is het, dat, waar Tacitus (Hist. 1, 36) iacere oscula heeft, we bij Martialis (en zo ook bij Phaedrus en Juvenalis) vinden: basia iactare $(\mathrm{I} 3,7)$, zodat dus osculum door basium, en iacere door zijn frequentativum iactare (zie desbetreffende §) vervangen en de gehele uitdrukking in een populaire sfeer overgegaan is.

\section{bucca-os.}

Hoewel de betekenis van bucca: „een mondvol” óók tot de populaire sfeer behoort, is het toch vooral de volkomen gelijkstelling van bucca en os, die een uitgesproken populair karakter draagt. (Reeds uit de geminatie - cc - blijkt de populaire origine van bucca!) Volgens NELSON zou bucca=os in Petronius' dagen nog slechts beperkt geweest zijn tot de gecultiveerde omgangstaal. Bij Martialis treffen we bucca=os zes maal aan, (I 41, 13; II 28, 4; III 75, 5; XI 61, 2; XII 24, 5; XIV 64, 1), op welke plaatsen vaak sprake is van obscene praktijken. Een duidelijk populair karakter draagt I 41, 13:

Quod bucca est vetuli dicax cinaedi.

Bucca ,een mondvol" vinden we op twee plaatsen (VII 20, 8; $X 5,5)$, nog gesteund door het deminutivum bucella, terwijl op III 17, 4 buccae gelijk is aan genae (wangen). De hier voorkomende uitdrukking sufflavit buccis---suis schijnt populair te zijn, vgl. RUCKDESCHEL p. 39.

Tegenover de tien genoemde plaatsen met het zeker populaire bucca wordt os echter negen maal zo vaak gebruikt door Martialis die dus in deze het populaire element wel druppelsgewijze toelaat in zijn oeuvre, maar in het algemeen vasthoudt aan de destijds nog bestaande norm van het "literaire” Latijn.

Hetzelfde geldt ook voor de beide synoniemen:

$$
\text { caballus-equus, }
$$

waarvan het eerste het meer populaire woord was, zoals b.v. het fr. cheval bewijst. Bij Martialis vinden we nog een overheersing van equus (26 maal), terwijl caballus 5 maal bij hem voorkomt, waarvan eenmaal als eigennaam, n.l. in I 41, 17 Tettius Caballus, waarop in vers 20 caballus volgt bij wijze van woordspeling. Men zou kunnen zeggen, dat de plaatsing van caballus, steeds op het einde van het vers, wijst op metrische invloed, ware het niet, dat deze overweging verzwakt wordt door het 
feit, dat ook equus, op slechts énkele uitzonderingen na, steeds als verseinde gebezigd wordt door Martialis.

\section{capillus-crinis-coma.}

Mededelingen van verschillende geleerden (o.a. ERNOUTMEILLET), het gebruik van bovenstaande woorden door diverse schrijvers (b.v. Vitruvius: crinis 1 maal, capillus zeer vaak) en tenslotte het voortleven in de Romaanse talen, wijzen erop, dat capillus wel het woord is, dat op den duur de andere synoniemen verdrongen heeft en dus wel het meest populair geweest zal zijn. Bij Martialis vinden we crinis 19, capillus 32 , en coma 48 maal. Hoewel capillus dus niet overheerst, is crinis toch in de minderheid bij hem. Bovendien kunnen we hier rekening houden met de invloed van het streven naar variatio, welke o.a. zeer duidelijk aan de dag treedt in XIV 26:

\section{Crines.}

Chattica Teutonicos accendit spuma capillos:

Captivis poteris cultior esse comis.

AXELSON p. 51 wijst erop, dat capillus het „Normalwort” geweest moet zijn, dat in de meer verheven stijl van epos en tragedie niet geliefd was; een bepaald vulgair karakter heeft capillus echter zeker niet.

\section{clunes-nates.}

Volgens ERNOUT-MEILLET (s.v. clunes) is clunes populair of een technische term; het is practisch gelijk aan nates, hoewel Martialis III 53, 2 een onderscheid schijnt te maken. Volgens ThLL s.v. wordt clunes gebruikt door: Plaut., Lucil, Laber., Lucr., Hor.sat., Priap., Manil., Cels., Petron., Gloss., Plin.nat., Mart., Juv., posteriores. Bij Martialis komt clunes (ook de singularis) 4 maal voor, nates (steeds Pluralis) echter 11 maal. serpens-anguis-vipera.

Het eerste was wel het meest geliefd in de omgangstaal, ook die van het volk; vooral in de "koperen" Latiniteit was het in gebruik, waarna het ook in de Romaanse talen is overgegaan. Bij Martialis vinden we (het poëtische) anguis 2 maal, serpens 3 maal en vipera 5 maal. Volgens SCHNEIDER zou het gebruik van deze woorden door metrische redenen bepaald zijn, maar dit lijkt mij onwaarschijnlijk, daar ze én in dactyli én in nietdactyli voorkomen. J. W. SPAETH Jr., die in een artikel, getiteld "Martial and Vergil" (in: Transactions and Proceedings of the American Philological Association LXI (1930), p. 19-28), de samenhang tussen Martialis en Vergilius behandelt, wijst erop, 
dat anguis XIV 177, 1 ontleend is aan Verg. Aen. VIII 289 en 697. De genoemde plaatsen luiden respectievelijk:

(Mart.): Elidit geminos infans nec respicit angues.

(Verg.): Geminosque premens eliserit anguis.

- en: Geminos a tergo respicit anguis.

Anguis is dus ook bij Martialis wel duidelijk poëtisch, maar ook hier weer is aan het populaire woord niet overtuigend de voorkeur gegeven.

\section{sophus-sapiens.}

BERTSCHINGER deelt ons op pag. 25 mede, dat sophus, volgens CAUSERET pas in de tijd van Phaedrus, die dit woord 3 maal bezigt, in het Latijn verschenen, reeds bij Lucilius voorkomt en toen reeds in de sermo vulgaris gebruikelijk was (sophia, bij Martialis twee maal voorkomend, vinden we reeds bij Ennius!). Ook FRIEDLAENDER veronderstelt, dat sophos aan de omgangstaal ontleend is. Sophus, substantivisch gebruikt, komt bij Martialis slechts eenmaal voor (VII 32, 4), evenals zijn synoniem sapiens (I 15, 11).

\section{terra-tellus.}

Het poëtische tellus, dat op den duur verloren gegaan is, heeft Martialis 13 maal; hiertegenover staat een duidelijke meerderheid van terra, welk woord echter geenszins uitsluitend in de populaire taal voorkomt.

\section{toxicum-venenum-virus.}

Volgens BERTSCHINGER (p. 24 vv.) was het Griekse leenwoord toxicum reeds in de tijd van Plautus gebruikelijk in de omgangstaal. Bij Martialis vinden we het op drie plaatsen

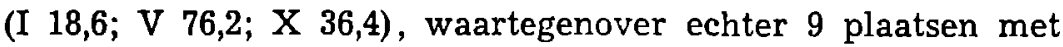
venenum staan. Virus komt bij hem 4 maal voor, o.a. XIII 2, 8: in illos virus habe, waar het dus voorkomt in de populaire omschrijving met habere, een van de z.g. „Allerweltsverba". Hier ligt het populaire element echter méér in de uitdrukkingswijze als zodanig dan in de afzonderlijke woorden.

\section{c. Verba.}

comedere-edere-manducare-vesci.

De gegevens, welke NELSON ons verschaft over het voorkomen van deze synoniemen bij diverse schrijvers, vermeerderd met de cijfers, welke ik voor Martialis vond, kan men aldus in een schema bijeenbrengen: 
Synoniemen: Plaut. Cic. Plin.nat. Sen.phil. Petron. Mart.

\begin{tabular}{lrrrrrr}
\hline comedere & 23 & 13 & 6 & 3 & 10 & 6 \\
edere & 81 & 10 & 106 & 30 & 3 & 16 \\
manducare & - & - & 11 & 1 & 2 & - \\
vesci & - & 18 & 70 & 2 & - & 2
\end{tabular}

Hieraan kunnen we o.a. toevoegen, dat in de korte fragmenten van Keizer Augustus, die menig omgangstaal-element bevatten, manducare en comedere naast elkaar gebruikt worden; en verder, dat beide verba in de Romaanse talen bewaard zijn, b.v. fr. manger, sp. comer. Edere, dat bij Martialis nog de meerderheid heeft, is op den duur verloren gegaan; comedere, dat een groter klankvolume heeft en door com- wel meer expressief is, is bij hem geheel gelijk aan edere; vescor, dat reeds sinds Sen.phil. „ouderwets" schijnt te zijn, heeft Martialis slechts twee maal, terwijl manducare, dat in bovenstaand schema nog maar schaars vertegenwoordigd is, (Plin. uitgezonderd), door Martialis nergens geschreven is.

invenire-reperire.

Men is gewoon deze werkwoorden niet geheel op één lijn te stellen, maar tussen beide een betekenis-onderscheid aan te: nemen, in die zin, dat invenire zou betekenen "toevallig vinden" en reperire "terugvinden, wat men zoekt". BAEHRENS wijst er echter op (pag. 50), dat tussen beide verba een scheidslijn van geheel andere aard bestaat, en wel deze, dat invenire, hoewel het ook reeds vroeger voorkomt, maar dan haast uitsluitend bij meer vulgaire auteurs, toch met name in de Keizertijd is opgekomen, en dat reperire thuis hoort in de meer verheven stijl.

Hij neemt dus niet zozeer een verschil in betekenis, als wel een verschil in "sfeer" aan tussen beide verba. De gegevens, welke NELSON ons biedt in deze, stemmen hiermee volkomen overeen:

$\begin{array}{lcc} & \text { reperire } & \text { invenire } \\ \text { Petron. } & - & 41 \\ \text { Vitruv. } & 6 & 100 \\ \text { Tacitus } & 80 & 10\end{array}$

Dus bij Petron. en Vitruv. een duidelijke voorkeur voor invenire; bij Tacitus(!) voor reperire. Bij Martialis nu vinden we naast 18 plaatsen met invenire slechts één plaats met reperire, en hier is het dan m.i. vooral een metrische dwang, die tot het gebruik van reperire leidde, daar invenit niet, repperit echter 
wel past in bedoeld vers (XII 93,2). Vergelijken we deze plaats met VI 51,2, waar invenire gebruikt wordt, dan zien we, dat er voor Martialis tussen beide verba geen enkel verschil in betekenis bestaat, daar beide verba op genoemde plaatsen betekenen: ,een manier vinden (om iets te kunnen doen)", en in beide gevallen gevolgd worden door: qua ratione....

\section{gaudere-laetari.}

Van deze verba is, weer volgens BAEHRENS, p. 64, alleen het eerste bewaard in de Romaanse talen (waarmee waarschijnlijk correspondeert de voorkeur voor gaudium/gaudia, fr. joie). Reeds bij Martialis vinden we, naast tweemaal laetari, in de meerderheid der gevallen gaudere.

\section{occidere-interficere.}

Occidere is het werkwoord, dat vooral in de populaire taal, en in het algemeen in de omgangstaal, gebruikt werd om het begrip „doden" weer te geven, misschien omdat in dit woord, een compositum van caedo, deze betekenis op meer expressieve wijze aanwezig is dan in interficere, een compositum van facio, welk simplex op den duur als "Allerweltsverbum" gebezigd werd. BAEHRENS vraagt zich p. 50 af, of in de teksten occidere misschien meer duidt op doodslag en interficere misschien meer verbonden wordt met fame, veneno, etc. Voor Martialis, die interficere nergens, en occidere op 2 plaatsen gebruikt, gaat dit in ieder geval niet op.

Intussen doet de geringe frequentie van occidere denken aan datgene, wat AXELSON p. 65 vv. mededeelt over de verba, die het begrip "doden" aanduiden. Hij komt daar tot de conclusie, dat zowel occidere als interficere niet poëtisch zijn en derhalve in de verheven dichtertaal zoveel mogelijk vermeden worden. In de niet-lyrische werken van Hor., en bij Juv. komt occidere vaker voor, terwijl interficere bij beiden ontbreekt, omdat het vers-technisch minder bruikbaar is dan zijn synoniem. Overigens 1s, over het algemeen gesproken, de frequentie van beide woorden bij de Romeinse dichters zeer gering.

Aan het meer populaire karakter van occidere doet dit alles echter geen afbreuk ${ }^{12}$ ).

$$
\text { pati-sinere. }
$$

PRAUN, die o.a. een onderzoek instelde naar de infinitief-

12) Ook woorden als necare, trucidare, obtruncare, interim e re, perimere komen bij Martialis niet of slechts een enkele maal voor. Het door AXELSON voorgestelde speciale onderzoek, betreffende de weergave van het begrip "doden" door de dichters, valt als zodanig buiten het raam van mijn studie, 
constructies bij Vitruvius, wijst erop, dat patior, gevolgd door acc.c.inf., 32 maal voorkomt bij Vitruvius, maar sino aldus nergens. Voorts deelt hij ons mede dat Gaius eenmaal sino heeft, maar dan aldus verklaard: „ut sinat, id est patiatur”, en dat ook bij andere juristen sino ontbreekt; in de Romaanse talen vinden we alleen patior terug. Bij Vitruvius ontbreken voorts ook impedio en veto, waarvoor we steeds vinden: non patior. Horatius geeft in ep. en sat. de voorkeur aan patior, terwijl van sino alleen de imperativus sine voorkomt, welke zich, gemechaniseerd (als age), langer gehandhaafd heeft.

Bij Martialis vinden we patior 2 maal, sino 7 maal met acc. c. inf.; de imper. sine heeft hij nergens; veto komt 11 maal voor, impedio eenmaal (maar dan met objects-accusativus). Van enige invloed van de omgangstaal en van de latere toestand dus nog geen spoor!

plorare-flere.

LöFSTEDT komt in zijn commentaar op de Peregr. Aeth. p. 321 tot de conclusie, dat plorare, het woord uit de omgangstaal, in de latere Latiniteit flere overwonnen heeft. Bij Petronius komt flere in de taal van de liberti niet voor, wel plorare. Ook heeft hij lacrimare nergens, al komt het substantivum lacrima wel voor. Men zou zich kunnen afvragen, of alleen het grotere klankvolume geleid heeft tot de overwinning van plorare; BAEHRENS haalt n.l. op p. 52 uit de z.g. „differentiae” het volgende aan; "lacrimare levis structura cordis est, flere gravioris adfectus est, plorare violentioris". Zo zou dus ook de drang naar grotere expressiviteit mede in het spel geweest kunnen zijn. Martialis heeft flere 19 maal (waarnaast twee maal het langere deflere=flere voorkomt); zelfs korte vormen als fles, flet, flens lezen we bij onze dichter! Plorare, dat 13 maal gebruikt wordt, is hiermede ruim vertegenwoordigd. Het wordt nog ondersteund door plorator, XIV 54, 1. Lacrimare lezen we nergens, lacrima echter op meerdere plaatsen ${ }^{13}$ ).

\section{portare-ferre.}

Het klankvolume en de overlevering in de Romaanse talen geven reeds een duidelijke aanwijzing, aan welk van beide

13) AXELSON p. 28v wijst erop, dat plorare in het hogere proza (Caes., Sall., Tac., e.a.) en in de epische en tragische poezie zoveel mogelijk vermeden wordt, terwijl het in het satirisch-epigrammatische, maar toch ook in het veredelde lyrisch-elegische genre geheel legitiem is, juist om zijn emphatisch en drastisch karakter. Het vulgaire karakter van plorare wordt door hem daardoor echter niet in twijfel getrokken. 
synoniemen in de omgangstaal de voorkeur zal gegeven zijn; bij Martialis is portare echter nog ver in de minderheid.

Portare draagt dan ook niet zo duidelijk het stempel van de omgangstaaal als dat b.v. bij lassus het geval is. (AXELSON p. 30). We lezen dit verbum bij dichters als Tibullus, Lucanus, Vergilius, Silius, en dan niet alleen om vers-technische redenen! Dit woord behoort dus, ondanks zijn min of meer populair karakter, zeker niet tot de niet-poëtische woorden.

\section{quaerere-velle.}

Wanneer ik deze beide verba in deze paragraaf opneem, geschiedt dit niet om ze in alle opzichten als synoniemen naast elkaar te plaatsen. Slechts voorzover quaerere op het terrein van velle komt is het hier voor mij van belang. Quaerere (= ,willen") + inf. komt alleen voor bij dichters en niet-klassieke prozaschrijvers. Bovendien vinden we quaero=volo terug in het sp. quero. Martialis biedt ons voor dit gebruik enkele zeer duidelijke voorbeelden, o.a. VII 80, 5; I 48, 7; IV 89, 3.

\section{orare-rogare.}

Volgens PRAUN ontbreekt orare geheel bij Vitruvius; wél heeft hij rogare en andere verba. Voorts wijst ook NELSON erop, dat orare steeds meer vervangen werd door rogare. Bij Martialis staat tegenover 11 maal orare een grote meerderheid van rogare.

vadere-ire.

Reeds bij Vitruvius (zie PRAUN) is de vervanging van ire door vadere merkbaar; de composita van ire heeft hij echter zeer vaak. Vooral de korte vormen $i$, is, it werden vervangen door vade, vadis en vadit; gaandeweg is echter het gehele verbum ire te gronde gegaan. Er zijn auteurs, waar nog imus, itis, ite voorkomen, maar niet de kortere vormen.

Martialis maakt van de composita van ire zeer vaak gebruik; van het simplex vinden we 20 één-lettergrepige vormen (waarvan 18 maal de imperat. $i$, welke menigmaal zuiver mechanisch gebruikt wordt, b.v. X 96, 13: $i$, cole nunc reges); voorts heeft Martialis 60 twee-, en 7 drie-lettergrepige vormen van ire. Dus ook bij hem een sterk overwicht van de meerlettergrepige vormen. Vadere lezen we slechts 6 maal, op sommige plaatsen waarschijnlijk in dienst van de variatio; b.v. XI 1. 4: vadas et redeas. Als het dus juist is, dat Martialis vadere gebruikt ter vervanging van ire, dan is het, blijkens de voorkomende vor- 
men van vadere ${ }^{14}$ ) in plaats van de kortere vormen $i$, is en eas.

\section{d. andere woordsoorten.}

$\mathrm{Na}$ in het voorafgaande enige doubletten van adiectiva, substantiva en verba behandeld te hebben, wil ik nu ook op andere woordsoorten de aandacht vestigen. Allereerst dan het gebruik van

\section{homo i. pl. v. (pronomen) is.}

De omgangstaal gebruikt soms ter vervanging van het korte, klankarme, kleurloze en zeer frequent gebezigde is de omschrijving met het meer concrete en aanschouwelijke homo. Ook bij Martialis vinden we hiervan enkele voorbeelden, o.a. II 40. 2: novi hominis fraudes $=$ novi eius fraudes.

Men zie ook VI 33, 4 en XIV 212, ${ }^{15}$ )

$$
\text { pulchre = bene. }
$$

Eveneens veelvuldig voorkomend in de omgangstaal is het gebruilk van het meer expressieve pulchre voor bene. Opvallend is, dat pulchre, op alle 4 plaatsen, waar Martialis het schrijft, de betekenis van bene draagt.

I 77, 1: pulchre valet Charinus et tamen pallet.

Zeer duidelijk zijn ook II 58, 1 en III 95, 13.

In XII 17, 9 tenslotte vinden we de uitdrukking: pulchre est alicui ,het gaat iemand goed, hij heeft het best".

$$
\text { subinde }=\text { saepe. }
$$

Volgens NELSON p. 114, begint subinde sedert Vell. en Sen. een synoniem te worden van saepe, saepius, al is dit laatste bij Petronius nog volstrekt niet uitgeschakeld: een slaaf kon bij hem nog gerust saepe zeggen. Bij Phaedrus heeft subinde, van de twee malen dat het voorkomt, eenmaal de betekenis van saepe, aldus PETERS p. 112. Phaedrus heeft hiernaast nog 12 maal saepe. De gelijkstelling van subinde en saepe is zeker niet klassiek; saepe sterft in de gesproken taal langzaam uit en leeft niet voort in de Romaanse talen.

Martialis bezigt saepe zeer vaak, saepius 10 maal. Bij hem vormt subinde, gevolgd door een twee-lettergrepig woord, steeds het verseinde! Op enkele plaatsen is ook bij onze dichter subinde gelijk aan saepe, b.v. V. 39, 5 en 6, waar Martialis zich richt tot Charinus, die, door zijn hoesten, keer op keer zijn

14) XI 1, 4 vadas; I 70, 1; III 4, 1; XI 104, 1 vade; II 69, 5. 5 vadis.

15) Populair is ook het als scheldwoord bedoelde os hominis! (IX 94, 2). 
dood aankondigt en evenzovele malen cen nicuw testament maakt:

signa rarius aut semel fac illud, mentitur tua quod subinde tussis.

Zo ook nog b.v. IV 50, 1.

statim-continuo.

PRAUN is van mening, dat continuo in Vetruvius' dagen zeker niet meer in de omgangstaal thuishoort. Statim gaat dan steeds meer overheersen. Martialis gebruikt statim 3 maal (in hendecasyllabi) en continuo 2 maal (in dactyli).

\section{subito-repente.}

Mededelingen van LöFSTEDT, NELSON e.a. wijzen er onomstotelijk op, dat subito het woord van de omgangstaal is. Martialis geeft aan geen van beide een duidelijke voorkeur, want hij schrijft repente 8 , subito 7 maal. Subito heeft bij Martialis echter nog nergens de later gewone betekenis „dadelijk, terstond" (het Brabantse ,sebiet) "

\section{non-haud.}

Bij auteurs als Rhet. Her., Vitruv, Petron. komt de negatie haud, die, aldus HOFMANN, p. 79, allengs uit de populaire taal verdween, niet voor. Bij Martialis leest FRIEDLAENDER haud slechts eenmaal, en wel in IX 2, 8, welke lezing door LINDSAY en HERAEUS bovendien nog als foutief beschouwd wordt.

\section{forsitan-fortasse.}

LöFSTEDT, Peregr. Aeth. p. 47 vv., heeft als zijn mening te kennen gegeven, dat forsitan het woord was van de omgangstaal, fortasse daarentegen van de meer verheven taal. AXELSON wijst er echter op, dat Verg. fortasse slechts een maal heeft tegenover een meerderheid van (fors, forsan) forsitan; iets eenders vinden we in Ovidius' elegiëen, 'bij Lucr., Tibull., Prop., Hor. Oden., Lucan., Sen. trag. Hij komt dan ook tot de conclusie, dat fortasse niet het geliefde woord is van de verheven taal in het algemeen, maar slechts van het verheven proza. „An dem prosaischen Charakter von fortasse stiess sich die Poesie weitaus mehr als an dem volkstümlichen von forsitan."

16) Hoewel AXELSON p. 33 zegt: „Das volkstümlichere Wort war immerhin das im Romanischen fortlebende $s u$ b i t $o$, während $r$ e e $n$ t e ein feierliches, wohl auch etwas altertümlicheres Gepräge gehabt haben wird", wijst hij er toch op, dat $s$ u b t o daarom nog niet vermeden is in de hoger poezie (b.v. Ov. subito meer dan 50, repente slechts 3 maal; Verg. subito 26 , repente 14 maal). 
In deze zin zal dan ook de volgende uitspraak van NELSON p. 112 gewijzigd dienen te worden: „Zo komt het zeer litteraire fortasse nergens meer bij Petronius voor en men vindt uitsluitend het in de omgangstaal overheersende forsitan."

Martialis nu heeft fortasse op 7 plaatsen, waarnaast forsitan 9 en forsan 6 maal voorkomen. De meer populaire woorden zijn bij hem dus wel in de meerderheid, maar het prozaïsche fortasse speelt toch ook een relatief grote rol, hetgeen in de minderverheven dichtertaal niet ongewoon is. Voor auteurs als Mart. en Juv. verbaast ons dit te minder, daar we, zoals reeds in de inleiding werd gezegd, in de periode van de Zilveren Latiniteit een vervaging van de grenzen tussen proza en poëzie zien intreden.

et-que-atque-ac.

Van deze synoniemen wordt het laatste, zoals door meerdere dichters, zo ook door Martialis geheel gemeden. Van de overige woordjes is, indien mijn telling juist is, de frequentie:

$$
\begin{aligned}
\text { et } & 1436 \\
\text { que } & 1105 \\
\text { atque } & 62
\end{aligned}
$$

-que, dat, volgens NELSON, in de omgangstaal van Petronius' tijd wel uitgestorven was, en dan nog alleen in zuiver literaire taal verwacht mag worden, is, hoewel minder frequent, toch nog rijkelijk vertegenwoordigd bij Martialis! Atque behoort zeker tot de hogere- en cultuurtaal.

$\mathrm{Bij}$ een door mij ingesteld woordfrequentie-onderzoek ten aanzien van de eerste twee boeken van Vergilius' Aeneis vond ik de volgende cijfers:

$\begin{array}{lccc} & \text { boek I } & \text { boek II } & \text { totaal } \\ \text { et } & 166 & 197 & 363 \\ \text {-que } & 251 & 276 & 527 \\ \text { atque } & 25 & 23 & 48\end{array}$

$\mathrm{Bij}$ Vergilius dus een zeer duidelijke meerderheid van -que. Bovendien zien we, dat de frequentie van atque in slechts twee boeken van Vergilius die van hetzelfde woord in Martialis' gehele oeuvre reeds benadert! Deze vergelijking verhoogt dus de waarde van de getallen, door mij voor Martialis gevonden.

propter-ob.

Is propter reeds vroeg het woord, waaraan de omgangstaal, en met name ook de volkstaal de voorkeur gaf, zeer bijzonder 
geldt dit voor de post-klassieke periode. $O b$ is dan het meer literaire woord. Bij Phaedrus vinden we ob nergens, propter daarentegen 6 maal, nog gesteund door quapropter en propterea. Ook Martialis geeft aan het klankvollere propter zeer duidelijk de voorkeur: hij heeft het $11 \mathrm{maal}$, (bovendien nog eenmaal propterea), terwijl ob slechts op één plaats voorkomt. Deze plaats verdient zeker onze aandacht; het betreft hier het epigram IX 22, vers 1 en 2:

credis ob haec me, Pastor, opes fortasse rogare, propter quae vulgus crassaque turba rogat.

M.i. is het niet voldoende, hier ter verklaring van het opvallende gebruik van de beide in het geding zijnde praeposities in twee opeenvolgende verzen, alleen maar het streven naar variatio te noemen. Waarschijnlijk is er meer: beide verzen ademen elk een eigen sfeer; Martialis distancieert zich hier immers zeer duidelijk van het gemene volk. En wellicht is het juist deze sfeer, die de dichter in het eerste vers, waarin ook fortasse voorkomt, ob doet gebruiken en in het tweede vers (met vulgus en crassa) propter.

Intussen zou het onjuist zijn, uit het bovenstaande te concluderen, dat $o b$ zonder meer het literaire woord is. Veeleer is $o b$ de verouderde vorm, die, na door Cic. en Caes. vermeden te zijn, bij Sall. weer tevoorschijn treedt. In poëzie echter zijn zowel $o b$ als propter niet geliefd. (Meer hierover biedt AXELSON p. $78 \mathrm{vv}$.) Komen deze praeposities dus toch voor bij Martialis, dan dienen we hierin wederom een concessie aan de taal van het proza te zien: het feit, dat Mart. hierbij een uitgesproken voorkeur voor 't meer populaire propter aan de dag legt, en, blijkens de aangehaalde verzen, zelfs een duidelijk onderscheid voelt tussen beide praeposities, wint, in het licht van het zo-even vermelde gezien, slechts aan betekenis.

Laten we, om tot een totaal-indruk te geraken, onze gedachten nog eens teruggaan over alle bovenvermelde gegevens, dan zien we, dat Martialis hier geen strakke lijn gevolgd heeft, in die zin, dat de maat, waarin hij bij de keuze uit de hem ten dienste staande synoniemen toegeeft aan de in de omgangstaal heersende tendenzen, haast van geval tot geval een andere is.

Soms geeft Martialis zeer duidelijk voorkeur voor het in de omgangstaal gebruikelijke woord te kennen (men denke b.v. aan propter, basiare, occidere, invenire), dan weer is het omgangstaal-woord wel is waar in de meerderheid, maar komt het 
meer "literaire" woord toch ook min of meer frequent voor (lassus-fessus, basium-osculum, et-que). Zeer gering is het overwicht o.a. van bellus en in weer andere gevallen blijkt van enige voorkeur in het geheel niets (statim, subito); in de minderheid zelfs zijn woorden als bucca, caballus, plorare, comedere, terwijl we ook enkele malen konden constateren, dat Martialis bepaalde mogelijkheden geheel niet benut heeft (men denke o.a. aan hetgeen ik bij de groep patior-sino vermeldde).

Uit dit alles blijkt dus, dat Martialis daar, waar hij de keuze had tussen een meer literair woord en een in de omgangstaal geliefd synoniem daarvan, er geen bezwaar in zag om het laatste te gebruiken, hoewel het moeilijk, zo niet onmogelijk is, hierin een bepaalde regelmaat te ontdekken.

We zagen voorts, dat zijn keuze soms door de dwang van het metrum bepaald werd, maar toch weer niet zo vaak als SCHNEIDER, die deze zaak speciaal onderzocht en daardoor misschien, onbewust, wel eens te gauw van metrische noodzaak spreekt, ons wil doen geloven. De variatio en de sfeer van het epigram bieden minstens even belangrijke verklaringsmogelijkheden.

Duidelijk is echter, dat Martialis ook ten aanzien van de zaken, in deze paragraaf besproken, bewust of onbewust omgangstaal-elementen in zijn epigrammen toelaat, en wel zo, dat ze haast willekeurig over zijn werk uitgestrooid schijnen te zijn.

\section{§ 4: SUFFIXEN.}

STEPHANI p. $33 \mathrm{vv}$ bespreekt achtereenvolgens zeer vele woorden, bij Martialis voor het eerst voorkomend of door hem voor het eerst in poëzie gebruikt, samengesteld met bepaalde suffixen. Onder deze suffixen zijn er meerdere, die in de omgangstaal zeer geliefd waren; ik behoef hierop niet nader in te gaan, daar ik hiervoor gevoeglijk kan verwijzen naar STEPHANI. In één opzicht echter zou ik mij van hem willen distanciëren. Wanneer STEPHANI n.l. aan zijn materiaal-verzameling overzichten toevoegt betreffende het voorkomen van groepen van woorden, samengesteld met suffixen als -tor, -trix, -ax, -alis, -icius etc., in de verschillende metra, wanneer hij dan op grond van zijn bevindingen meermalen concludeert, dat Martialis juist in die metra, waar men dit a priori ook zou verwachten, blijkbaar het meest nadert tot de omgangstaal, komt hij op gevaarlijk terrein. Zijn mededelingen werken wel zeer suggestief, maar enkele zakelijke overwegingen nopen ons toch een 
voorzichtiger standpunt in te nemen. Het moge dan juist zijn om aan innovaties een grote waarde toe te schrijven, men mag toch nooit, zoals STEPHANI doet, aan bepaalde suffixen qua tales een te groot belang hechten: een woord is niet populair, omdat het met een of ander suffix gevormd is! In dat geval komt men ertoe alle woorden, die tot een bepaalde groep behoren, ook over één kam te scheren. Ik maakte deze bedenkingen eerder reeds enige malen, maar hier moet dit toch zeer uitdrukkelijk worden vastgesteld. Ik moge mijn standpunt met enige voorbeelden nader toelichten:

Menige vorming met -osus heeft iets „triviaals" over zich (AXELSON p. 51) en is dan minder geschikt voor de hogere taal. Bij Martialis vond ik 60 van deze vormingen, in totaal 176 maal voorkomend; hierbij zijn er vele, die reeds bij Catull., Hor., Ov., Priap. gelezen worden. Martialis heeft echter ook innovaties op dit gebied: pediculosus, polyposus, pertricosus (dit laatste zeker populair); voor het eerst bezigt hij in poëzie: contumeliosus, exitiosus, gulosus (populair), pecuniosus. Een woord als annosus, dat ontbreekt in de klassieke literatuur en overigens bij velen van de beste auteurs, schijnt vooral te behoren tot de taal van de boerenbevolking en in het algemeen tot die van het lagere volk (RUCKDESCHEL p. 18); het gebruik van Martialis wijst ook in deze richting: I 105, 3; VI 27, 5. De betekenis van odiosus verzwakte in de familiaire taal tot "vervelend, ondragelijk". Zo ook bij Mart. II I, 8; VIII 6, I. Toch kunnen niet alle woorden van deze groep tot de populaire taal gerekend worden: de gegevens van de ThLL, o.a. s.v. ambitiosus, animosus, wijzen althans niet in deze richting. RUCKDESCHEL wijst er p. 98 op, dat de schrijfwijze formonsus blijkens de auteurs, waarbij ze gevonden wordt, misschien iets populairs heeft. Hij noemt in dit verband ook Martialis. De voornaamste editores plaatsen echter vrijwel steeds formosus in de tekst; in cod. $\mathrm{T}$ (!) lezen we echter in XI 66, I; VIII 53, 4; III 3, 1, 2 formonsus!

Een woord als balneator, door Martialis 2 maal gebruikt, treffen we ook aan bij Plaut., Petron., post.; hetzelfde geldt voor circulatrix (Priap., Mart., Mart. Cap.); textor (Plaut., Hor. ep., Mart. Juv.); comissator (Ter., Cic. 1 maal in redev., 1 maal in ep.; Liv., Petron., Mart., Apul., post.) ; fututor (Priap., Mart., inscr.); structor (= ,iemand, die een schotel opmaakt en opdient”) (Petron., Mart., Juv., Apul., Fronto) ; dicax lezen we bij Martialis I 41, 13 in de vulgaire verbinding dicax bucca cinaedi; salax lezen we bij Varro, Catull., Hor. sat., Colum., Sen., Priap., 
Plin., Mart., inscr., post.; bessalis hebben, naast Martialis, ook nog Vitr., Petron. en post. Ook de met bedoelde suffixen gevormde non-nova zijn dus vaak populair en dienen bij een beoordeling van Martialis' taalgebruik terdege meegerekend te worden; omgekeerd zullen er onder de nova ook zijn, die zeker niet populair zijn.

Men stelle dus niet de suffixen primair; temeer wanneer we bij SCHNEIDER lezen, dat hierbij vaak ook metrische redenen in het spel kunnen zijn (innovaties met -icius, een speciaal voor dactyli geschikt suffix, vinden we bij Martialis alleen in dactyli. Woorden met dit suffix gevormd schijnen over het algemeen populair te zijn.) Voorop plaatse men de betekenis, de gedachtesfeer van elk woord afzonderlijk; hierbij speelt ook de geschiedenis van de woorden een belangrijke rol. Men mag Martialis niet uitsluitend beschouwen vanuit vers-technisch oogpunt, maar primair dient men in hem de dichter te zien.

In dit verband wil ik ook wijzen op een groep van woorden, die wel niet direct tot de populaire sfeer behoren, maar die toch typerend zijn voor de taal van Martialis: de abstracta op -(i) tas. PETERS p. 84 wijst erop, dat we hiervan reeds een groot aantal aantreffen bij Phaedrus, hoewel zich hieronder geen enkele innovatie bevindt. Het grote aantal abstracta is typerend voor de Zilveren Latiniteit. Martialis nu heeft 37 van deze abstracta, met een totale frequentie van 92 ; hierbij vinden we 4 woorden, die vóór Martialis alleen bij proza-auteurs gevonden worden: debilitas, hospitalitas, procacitas, virilitas (allen in hendecasyllabi of choliamben). In een vers als VI 85, 7 heu, qualis pietas, heu, quam brevis occidit aetas staan deze abstracta zelfs pro concreto (de persoon Camonius Rufus). ${ }^{17}$ )

\section{§ 5: ADVERBIA.}

In het algemeen zijn adverbia wegens hun tekort aan aanschouwelijkheid weinig geliefd in de poëzie; bij dichters als Verg., Tibull., Prop. zijn de gewone typen (op -e, -o, -(i)ter) slechts schaars vertegenwoordigd. Bij Lucretius daarentegen zijn ze frequenter (AXELSON p. 62v). Men zou aan het veelvuldige gebruik van adverbia dus op zijn minst een meer prozaïsch karakter kunnen toeschrijven. Bij Martialis vinden we vele adverbia van genoemde typen: op -e 34 (totale frequentie 149) : op -o 6 (tot. fr. 39); op -(i) ter 18 (tot. fr. 83).

Hierbij komt dan, dat we in vele gevallen in het gebruik van

17) Dit vaker bij Mart., b.v. $X$ 33, 6 malus livor. 
de adverbia de invloed van de omgangstaal duidelijk kunnen onderkennen. $\mathrm{Zo}$ is de verbinding van bene en male met een adiectivum (zie RUCKDESCHEL p. 143) zeker populair; bij Caesar vinden we dit nergens, bij Cic. zelden, bij Hor. vooral in sat. en ep. Martialis heeft o.a. IV 10, 2 pagina - - non bene sicca; VI 93,11 bene tutam; VII 69, 8 bene nota; IV 67, 7 male divitis arcae; V 13, 2 male notus eques; VIII 25, 2 male aegrum. Ook een uitroep als $O$ bene! (VII 15,3), di bene! (XI 53,5) doet ons onmiddellijk aan de omgangstaal denken.

VII 31, $7 \mathrm{O}$, quam, Regule, diligenter erras (,Wat vergis je je toch deerlijk") : reeds FRIEDLAENDER wijst a.l. op het populaire karakter van dit adverbium, dat dient ter vervanging van oudere door veelvuldig gebruik afgesleten vormen.

Het zelfde geldt voor plane in II 41, 6. 7 et tres sunt tibi, Maximina, dentes/sed plane piceique buxeique, waar plane i.pl.v. valde gebruikt wordt. Hierbij kunnen we nog opmerken, dat, blijkens AXELSON p. 95, plane bij de beste auteurs van Gouden en Zilveren Latiniteit taboe is; alleen Lucr., Mart., Hor. sat. gebruiken het.

libenter was in poëzie zeker niet geliefd als zijnde een té prozaïsch woord. In AXELSON's onderzoekingsmateriaal (p. 63) komt het slechts uiterst zelden voor bij Hor. (niet in de Oden), Ov., Prop., Catull., Juv. Dat juist deze dichters een uitzondering maken is wel opvallend; was dit woord wellicht, behalve prozaïsch ook min of meer populair? Volgens AXELSON zou libenter buiten genoemde auteurs niet voorkomen; niet minder dan 10 (!) Martialis-plaatsen zag hij echter over het hoofd.

Het substantivisch gebruik van mane is zeker populair. We vinden het bij Cato, Lucil., Varro, Cic. ep., b. Afr., Colum., Hor. sat. (RUCKDESCHEL p. 54). Ik zou hieraan willen toevoegen de volgende plaatsen uit Martialis: I 49, 36; III 36, 1; VII 39, 1 .

Omnino komt in poëzie practisch alleen voor bij Lucr. en in de lagere genres. Martialis heeft het zelfs 6 maal.

Pulchre vervangt in de omgangstaal vaak het afgesleten bene. Ook hier weer blijft Martialis niet achter: I 77, I pulchre valet; XII 17, 9 bevat naast pulchre ook nog bene, zodat hier dus wel sprake is van populaire variatio.

Ook de verbinding van een adverbium met esse is met name in de omgangstaal geliefd. De uitdrukking pulchre est vinden we, blijkens RUCKDESCHEL p. 115, alleen bij Plaut., Catull., Hor. sat. Indien FRIEDLAENDER's lezing juist is, - maar dit 
wordt door HERAEUS betwijfeld -, zou hieraan ook Mart. XII 17, 9 toegevoegd kunnen worden: cum sit ei pulchre.

In plaats van het klankarme en qua functies overbelaste $u t$ gebruikt de omgangstaal o.a. qualiter (dit 3 maal bij Mart.); hiernaast komt ook taliter (i.pl.v. sic, ita) voor, maar vóór Martialis, die het in V 7, 3 schrijft, alleen in proza.

Scilicet is, aldus DEL s.v. "fréquent dans la l. parlée, souvent avec valeur ironique". Vgl. hiervoor Mart. I 51, 3.

Valde komt bij de door AXELSON onderzochte dichters slechts zelden voor; we lezen het alleen bij Catullus ( 2 maal) en bij Martialis III 44, 5 . Het is aan de omgangstaal ontleend, hoewel het daar door veelvuldig gebruik aan expressiviteit inboette.

Ook enkele adverbiale uitdrukkingswijzen dienen hier vermeld te worden. In plaats van una lezen we hier en daar, maar dan voornamelijk in omgangstaal, in unum. Bij Martialis VII 82, 3 nam saepe lavamur in unum tekent FRIEDLAENDER aan, dat we deze omschrijving o.a. ook vinden in Vulg. Ps. 132, I. (Toch lezen we op een andere plaats, Mart. I 96, 11, ook nog una lavamur).

De verbinding van plusminus met een telwoord behoort volgens RIEMANN p. 584 al evenzeer tot de familiaire taal. Martialis heeft IX 100, 4 plusminus decem; VIII 71, 4 plusve minusve duae.

Tot slot de uitdrukking ad summam, die zeker aan de omgangstaal ontleend is (Petron., Cic. vooral ep., Sen. phil.); bij Martialis XII ep. 12 lezen we: - ingenium, bibliothecas, theatra, convictus, - ad summam omnium illam, quae....

\section{§ 6: HET GEBRUIK VAN VERBAAL-COMPOSITA.}

Bij een bestudering van Martialis' woordenschat dient ook het gebruik van verbaal-composita de aandacht. SCHNEIDER p. 46 heeft in dit opzicht reeds opgemerkt, dat Martialis het woord congelatus gebruikt in XI 98, 7 (choliamb.), terwijl we V 9, 3 (dact.) het simplex gelatus vinden; zo lezen we XII 67, 3 (hendec.) consecravit, terwijl in I 116, 1 (dact.) sacravit staat; volgens SCHNEIDER gebruikt Martialis hier in dactyli om metrische redenen de simplicia. Men zou hieruit moeten concluderen, dat Martialis daar, waar het hem door het metrum mogelijk wordt gemaakt, de composita gebruikt. Bij nader toezicht blijkt echter, dat de mededelingen van SCHNEIDER onvolledig zijn: gelatus vinden we ook in IV 46, 10 (hendec.); consecra- 
re lezen we eveneens IX 101, 2 (dact.). Wordt hierdoor dus het betoog van SCHNEIDER verzwakt, dan heeft hij ons toch in ieder geval op een belangrijk probleem attent gemaakt. Beter echter is het om niet uit te gaan van het metrum als beslissende factor; een woord als sacrare (tegenover consecrare) was, getuige RUCKDESCHEL p. 30, wel archaïsch-solemneel getint; sacrare is even goed geschikt voor de andere versmaten als voor dactyli; dat Martialis het simplex echter toch alleen in dact. gebruikt, krijgt, in het licht van RUCKDESCHEL's mededeling, nu een geheel andere betekenis.

Zo lezen we het simplex lassare 7 maal bij Martialis, steeds in dact.; hiernaast staat delassare in X 5, 17 (choli.): delassare is wel meer vulgair, daar we het buiten Martialis nog vinden bij Hor. sat. en Plaut.

Het verbum memorare heeft in de familiaire taal wel de betekenis „zeggen, vertellen" (DEL s.v.); zo ook bij Martialis XII 53,6 . Commemorare lezen we nergens bij onze dichter. Blijkens NELSON p. 107 werd het simplex geprefereerd in de volks- en omgangstaal, in de dactylische poëzie en in het Zilveren proza. In dit licht zullen we dan ook de strenge houding van Martialis moeten beschouwen.

Monstrare heeft t.o.v. demonstrare de voorkeur bij Plaut., Hor., Verg., Ov.; het is ook overgeleverd in de Romaanse talen. Het compositum overweegt echter bij Varro, Cic., Caes., Plin. nat., Quintil., Tert., August. civ., en is dus blijkbaar uitgesproken prozaïsch; in de latere omgangstaal (Peregr.Aeth., Vulg.e.d.) ontbreekt monstrare niet; het simplex komt dus voor in de Oud-, en Laat-Latijnse omgangstaal en bij de dichters. Martialis' keuze is wel typerend: hij heeft monstrare 3 maal in dact. en één maal in choliamben; demonstrare ontbreekt geheel. In de latere omgangstaal heeft echter het verbum ostendere $(=$ monstrare) de voornaamste plaats ingenomen (Peregr. Aeth., Vulg.): reeds bij Martialis lezen we dit verbum 3 maal in hendec. en 2 maal in dact.!

Disperire is volgens RUCKDESCHEL p. $35 \mathrm{v}$ vulgair; bij Martialis lezen we de vervloeking dispeream 5, dispereas 1 maal.

Imponere gebruikt Martialis 4 maal in de gewone zin, maar even vaak in de betekenis "bedriegen" (III 57, I; IV 40, 10; IV 79, 2; V 36, 2). Het laatste komt blijkens DEL s.v. pono reeds voor in de familiaire taal van Cicero's dagen, b.v. Cic. ad $\mathbf{Q}$. fr. 2, 6, 5. (Men denke hier aan impostor, impostura (Christel. Latijn), en aan het fr. imposteur, imposture). Ook een ander 
compositum van ponere is hier van belang: BERTSCHINGER p. 34 deelt ons mede, dat ponere i.pl.v. apponere, waar het het opdienen van spijzen betreft, tot de omgangstaal behoort. (Cato, Hor. sat., Ov., Petron., Plin, min., Phaedr., Mart., Juv.) Bij Martialis vinden we apponere aldus nergens, maar uitsluitend ponere: III 50, 8; IV 69, I; etc.

\section{$\S 7:$ DE FREQUENTATIVA EN DESIDERATIVA.}

Wanneer Martialis, alleen om metrische redenen, VIII 3, 21 cantare (- - v) schrijft voor canere $(v \cup v)$ sp. 11, 6 captare ( $\vee$ u $\vee$ ), VIII 59, 11 dormitantem (- - -) voor dormientem (- -- ), steunt hij op een in de omgangstaal bestaande gewoonte, waar de frequentativa vaak hun oorspronkelijke kracht verloren hebben en practisch gelijk geworden zijn aan de simplicia. Toch moeten we t.a.v. Martialis constateren, dat hij in het algemeen de frequentativa in hun oorspronkelijke betekenis gebruikt. Van een verzwakking van deze betekenis is slechts zelden sprake (voornamelijk wel bij de afgesleten verba cantare en captare); Martialis voelt dus blijkbaar nog sterk de kracht van het frequentativum; een versterking ervan door middel van woordjes als saepe, semper, etc. vinden we bij hem zo goed als nergens. Dat hij de frequentatieve betekenis ook uitdrukkelijk bedoelt, blijkt wel uit het feit, dat hij naast actitare (- u - u) causas (1 17, 1 hendec.) in dact., waar actitare $(-u-v)$ onbruikbaar is, de omschrijving semper agis causas $(179,1)$ gebruikt. Zo ook 1 95, 1 clamas semper. Op dit gebied vinden we slechts enkele innovaties: geheel nieuw is expulsare, voor het eerst in poëzie heeft Martialis actitare.

Belangrijker zijn voor ons onderwerp echter de door Martialis gebezigde desiderativa op - $(t)$ urire. Het is een over het algemeen weinig productieve groep; we vinden ze voornamelijk in het Oud-Latijn, verder bij Cic. ep., bij de satirici (Petron!), hetgeen wijst op het populaire karakter ervan. Bij Martialis vond ik cenaturire en cacaturire (XI 77, 3) (beide nova!); voorts esurire, een verbum, dat voornamelijk bij meer populaire auteurs voorkomt; FRIEDLAENDER heeft III 93, 18 nupturire, waar anderen nuptuire (volgens GEORGES een „Nebenform”) lezen. Opvallend is, dat genoemde desiderativa voor de gedachtesfeer van Martialis allen affectdragers zijn!

\section{§ 8: „ALLERWELTSVERBA.”}

De omgangstaal maakt in vele gevallen gebruik van verba als dare, facere, habere in de zin van z.g. "Allerweltsverba”. 
Hiervan wordt op enige plaatsen in deze studie gewag gemaakt, maar een iets uitvoeriger en samenvattende behandeling is hier wel op zijn plaats. ${ }^{14}$ )

Het verbum dare wordt door Martialis op zeer vele plaatsen in obscene zin gebruikt, waar hij spreekt van een meretrix, die een man "gelegenheid geeft." Men zou hierbij aan een euphemisme kunnen denken, ware het niet, dat Martialis op minstens evenzovele plaatsen de zaak bij haar ware naam noemt. Veeleer was dit de, in de omgangstaal geldende, "technische" term. (In dezelfde zin bij Martialis ook promittere; het omgekeerde wordt door negare aangeduid.)

De uitdrukking verba dare (,bedriegen") is, blijkens BERTSCHINGER p. 34, RUCKDESCHEL p. 165 zeker ontleend aan de populaire omgangstaal. Bij Martialis lezen we deze omschrijving (een van de vele voor het begrip "bedriegen") vier maal.

Het in dactyli practisch onbruikbare basiare komt voornamelijk in de andere versmaten voor; in dactyli vinden we omschrijvingen als basia dare (II 10, 1; II 21, 1; etc.) en oscula dare (XI $23,13)$. Ook al schijnt het metrum dan de directe oorzaak te zijn van het gebruik dezer omschrijvingen, we mogen toch wel aannemen, dat Martialis ook hiervoor steun vond in de omgangstaal, waarin overigens ook basiare zelf reeds thuis hoorde.

Hetzelfde geldt voor habere in de omschrijving nomen habere (XIII 97, 2; VIII 33, 2) voor nominari. (Uitvoeriger SCHNEIDER p. 30 v.) ${ }^{19}$ )

In dit verband dienen ook vermeld te worden XIII 2, 8 in illos virus habe; het gebruiken van facere in obscene zin (b.v. I 46, 1 ,fac, si facis"); omschrijvingen als fac me ames (= ama me; zie syntactisch gedeelte).

\section{§ 9: GRAECISMEN.}

Met behulp van de lijsten der in het Latijn voorkomende Griekse woorden, samengesteld door O. WEISE, welke ik hiertoe vergeleek met de index van FRIEDLAENDER, vond ik bij Martialis 477 graecismen, met een totale frequentie van meer

18) Onder Allerweltsverba verstaan we verba (als de bovengenoemde), die ofwel zelf, ofwel in omschrijvingen dienen ter vervanging van werkwoorden, die door veelvuldig gebruik minder expressief geworden zijn, die dienen ter weergave van een minder oirbaar begrip, etc. Zie hiervoor HOFMA'NN, Umg. Spr. p. 165.

10) SCHNEIDER p. 31 noemt in dit verband ook de omschrijving met het, volgens hem meer populaire, a pella re in VII 92, 3; hier betekent a pellare echter zeker niet ,noemen". Van een omschrijving is dus geen sprake! 
dan 1600. Hierbij moet men echter bedenken, dat dan ook woorden als poeta, rhetor, nauta, astrum, etc. zijn meegeteld, woorden dus, die in Martialis' dagen reeds volkomen ingeburgerd waren in het Latijn en niet meer als graecismen werden gevoeld; anderzijds bevat het werk van WEISE, in vele gevallen door nieuwere onderzoekingen achterhaald, menige onjuistheid. Een woord als fungus b.v., door hem in verband gebracht met osóryos, is blijkens DEL s.v. wellicht van een mediterrane taal afkomstig. Aldus moeten de zojuist genoemde getallen natuurlijk met de nodige reserve beschouwd worden; desalniettemin blijft het beschikbare materiaal te uitgebreid om er hier een allesomvattende behandeling aan te geven. Dit zal beter in een afzonderlijke studie kunnen geschieden; voor elk woord zou n.l. moeten nagegaan worden, wanneer en langs welke weg het in het Latijn gekomen is; voorts tot welke begrips- en levenssfeer het behoort; bij welke auteurs het wordt aangetroffen; of er ook een Latijns synoniem van bestaat, en zo ja, of dit dan ook gebruikt wordt door de desbetreffende auteurs, en waarom het Griekse equivalent gebruikt wordt. Een grote moeilijkheid zal men vooralsnog ondervinden tengevolge van de onvolledigheid van de ThLL. En wat tenslotte ons onderwerp betreft: al is de omgangstaal van de eerste eeuw na $\mathrm{Chr}$. doorspekt met graecismen, hierom behoeven nog zeker niet alle Griekse woorden, door Martialis geschreven, populair te zijn. Het is dan ook om al deze redenen, dat ik hier wil volstaan met enige summiere opmerkingen.

Allereerst dan deze: Martialis gebruikte niet alleen die Griekse woorden, welke hij uit de omgangstaal van zijn dagen kende. We mogen aannemen, dat zijn kennis van het Grieks veel verder reikte. Dit blijkt, om slechts iets te noemen, uit persoonlijke vindingen, b.v. een woordpeling als Palinurus (III 78, 2) (Mart. zinspeelt hier op de afleiding van $\pi \dot{\alpha} \lambda(v$ ojpöv) en Argonautae (III 67, 10). (Martialis denkt aan ípyoi vxü̃a. = „luie schippers".) Het woord clinicus in de betekenis "geneesheer" was in Martialis' tijd gebruikelijk en werd dus algemeen verstaan; de verbinding van clinicus met xhivn "dodenbaar" (I 30, 2) is blijkbaar door Martialis zelf tot stard gebracht, (vgl. DOLDERER p. 10).

Absoluut onvolledig lijkt mij dan ook de zienswijze van BIRT p. 312: „Wenn Martial griechische Woerter einsetzt, so sind es zumeist nur die gewoehnlichen".

Evenals NELSON p. 8 aan de hand van enkele voorbeelden 
bewijst dat hel standpunt van MARBACH, die het gebruiken van een Grieks woord door Petronius zonder meer als een vulgair verschijnsel beschouwt, absoluut onjuist is, kan men ook STEPHANI's methode ten aanzien van Martialis' graecismen bestrijden. STEPHANI p. $6 \mathrm{vv}$ begint n.l. met het opsommen van die graecismen, welke door Martialis voor het eerst in de Latijnse literatuur, resp. in de Latijnse poëzie binnengebracht schijnen te zijn. Hierbij gaat hij dan ook na, hoe deze nova over de verschillende metra verdeeld zijn, en concludeert dan uit het feit, dat verhoudingsgewijze de meeste in choliamben voorkomen, dat Martialis dus in zijn choliamben de omgangstaal het meest nabij komt. (Maar wat ervan te zeggen, dat de hendecasyllabi in deze zelfs iets ten achter staan bij de dactyli? Hierover zwijgt STEPHANI). Allereerst lijkt het mij niet juist zich bij een oordeel alleen te baseren op de nova: onder de non-nova zullen er zeker zijn, die een meer populair karakter hebben dan verschillende nova! Voorts is het mijn persoonlijke ervaring, dat tal van andere populaire verschijnselen zeker niet primair in chol. of hendec. voorkomen. Op meerdere plaatsen heb ik dit in deze studie aangetoond. Bovendien mogen we niet vergeten, dat niet steeds de qualiteit, maar ook wel de quantiteitsverhoudingen van de metra Martialis ertoe dwongen een bepaald woord al dan niet te gebruiken. Het van origine Griekse statera X 55, 7 (hendec.) is, om zijn 2 beginconsonanten, voor een dactylus ongeschikt. Bovendien lezen we het niet alleen bij Martialis, maar ook bij Statius (!) als verseinde; het is dus wel metrisch bepaald! Eveneens mogen we niet over het hoofd zien, dat Martialis sommige woorden, die hij in chol. of hendec. heeft, óók in dact. schrijft. Waarom dan aan het eerste feit een grotere waarde toegekend? STEPHANI's meest principiële fout lijkt mij wel, dat hij zich (ook in de rest van zijn werk) blind staart op groepen van woorden, die een bepaalde eigenaardigheid gemeen hebben, zonder elk woord afzonderlijk te beschouwen. Het zeker populaire tisana lezen we b.v. alleen in dact. Een woord als epaphaeresis (VIII 52, 9: hendec) maakt echter zeker niet de indruk populair te zijn: we kunnen n.l. betwijfelen, of het wel algemeen bekend was. Veget. Mul. 3, 45, 2 heeft postero quoque die quasi epaphaeresis fit et - - sanguis detrahitur. Waartoe deze toevoeging van quasi en van de nadere verklaring sanguis detrahitur? Zie ook Veget. Mul. 5, 24, 5. Celsus 2, 7 spreekt slechts van detractio sanguinis.

Al met al dus redenen te over om hier de uiterste voorzichtig- 
heid te betrachten. Een nader onderzoek zal zeker uitwijzen, dat een belangrijk deel van Martialis' graecismen niet uit de omgangstaal stamt.

Vermeld dient nog te worden, dat Martialis in vele gevallen de oorspronkelijke Griekse declinatie handhaaft en dat niet alleen bij eigennamen. Geregeld lezen we bij hem accusativi als cercopithecon, ceston, cherson, colosson, endromida, hippodromon, lygdon, panaca, pelorida, phrenesin, pityonas, rhinocerota, trigona, (naast trigonem! Beide in dact. als verseinde!) tropin, etc. Ook dit wijst meer op een literair dan op een populair gebruik van deze woorden.

\section{$\S 10$ : LIJST VAN POPULAIRE WOORDEN, VOORZOVER NIET IN DE VOORAFGAANDE § $§$ BEHANDELD.}

Buiten de woorden, die in het voorafgaande besproken werden of die vallen onder de behandelde groepen, heeft Martialis er nog vele, die eveneens geput zijn. uit de woordenschat van de omgangstaal. Ik laat de voornaamste en voor mij controleerbare hier volgen en wel alphabetisch gerangschikt; elk woord gaat vergezeld van een verduidelijkend commentaar.

Alapa: komt niet eerder voor dan bij Phaedrus, Mart. en Juv. Het behoort tot de populaire sfeer. Martialis heeft V 61, 11 alapis - Latini: Latinus is een bekende mimen-speler; hier is dus een sterke reminiscentie aanwezig aan de populair getinte mimische stukken.

Allec: (HERAEUS leest hallec). DEL s.v.: „mot populaire de forme mal fixée". Ook bij Martialis roept het direct de sfeer van het alledaagse leven op: III 77, 5 putri cepas allece natantes.

Antequam: de puristen en de Klassieke taal geven de voorkeur aan priusquam; Caesar b.v. vermijdt antequam. Martialis heeft priusquam 2, antequam 3 maal. De in FRIEDLAENDERS Index niet vermelde plaats VII 67, 9 nec cenat prius aut recumbit ante, quam - bevat wel weer een voorbeeld van variatio.

Anus: DEL s.v.: „comme atta, etc. mot du vocabulaire familier." Hoewel dit woord zeldzaam is in de Keizertijd, heeft Martialis het toch 19 maal, o.a. ook als epitheton in verbindingen als testa anus, mentula anus, charta anus. Het komt practisch alleen voor bij populair getinte auteurs. Vgl. ThLL.

Apinae: DEL s.v.: „mot populaire, extrêmement rare et tardif." Martialis verbindt het XIV 1, 7 met het eveneens popu- 
laire tricae. ThLL s.v. verwijst naar Plin, nat. 3, 104 Apulorum urbes duas, quae in proverbi ludicrum vertere, Apinam et Tricam. Bij een dergelijke toespeling op een bestaande spreekwoordelijke uitdrukking mogen we zeker aan de volkstaal denken.

Arrigere: wordt door Martialis 11 maal gebruikt, steeds in obscene zin en in populaire omgeving.

Bascauda: een woord van vreemde oorsprong; vgl. Mart. XIV 99, lemma en vs. 1 . Komt alleen voor bij Mart., Juv. en gloss.

Cacare: DEL s.v.: „mot nu langage populaire et enfantin." Martialis heeft het 7 maal, waarbij XI 77, 3 cacaturio gevoegd kan worden.

Cacare lezen we voorts nog in Atellanae, Catull., satirici (Hor., Petron.), Phaedr., bij medici en op inscr. Ik vraag mij af, of het schrijven van de verba currere en cacare in één vers (Mart. III 44,11) zuiver toeval is. Zou hier niet een reminiscentie aan de in de volks-, of omgangstaal blijkbaar gewone uitdrukking cacatum currere aanwezig kunnen zijn? Vgl. Petron. 71, 8 ne - populus cacatum currat. (Zie NELSON p. 168).

Calva: een populair woord, dat door volksetymologie verbonden werd met calvus. Martialis ( 8 maal) kent het slechts in de dan voor de hand liggende betekenis „kale kop"; voorts lezen we het nog bij Pompon. Atell., Varro men., Liv. (1maal).

Capo: een nevenvorm van capus (Varro, Colum.) op o onis (vaak populair). De eerste syllabe is lang, en het werd waarschijnlijk wel gesproken met expressieve geminata. (It. cappone). Martialis heeft het III 58, 38 en XIII 63, lemma. De betekenis "eunuuch" doet al direct denken aan een typische Martialissfeer.

Caput: de synecdoche caput-homo, gebruikt als uitdrukking van toorn en spot, is speciaal eigen aan de omgangstaal; door RUCKDESCHEL p. 61 is dit voldoende bewezen. Ook Martialis levert hiervoor weer een voorbeeld: IV 68, 2 invisum pueris virginibusque caput.

Cerdo: ook hier weer het zelfde suffix -o, -onis. Ook dit woord is populair. (gloss.: cerdones pauperes infimi; Schol. Pers. 4, 51 per cerdonem plebeiam turbam significat). Het woord komt nog voor bij Juv. en op inscr. Martialis heeft het 5 maal in de betekenis ,schoenmaker".

Cevere: DEL s.v.: „vulgaire et souvent employé dans un sens obscène, à coté de cris(s) o" (Zie daar). Een duidelijke taal 
spreekt Mart. III 95, 13 sed paedicaris, sed pulchre, Naevole, ceves. Voorts nog bij Plaut., Juv., Pers., inscr.

Cimex: „wandluis". Als nomen insecti hebben het Liv. Andron., Plaut., Catull., Varro rust., Plin. nat., Mart. (XI 32, 1; XI 56, 5), post. De qualificatie van DEL als „mot populaire" lijkt mij iets te sterk; wellicht oók beschaafde omgangstaal.

Cirrus: blijkens ThLL s.v. wordt het „proprie” gebruikt door Varro, Juv., Suet., Tert., Itala. Zo ook Mart. X 83, 6 cirris grandibus. „Translate” heblben het Plin. nat., Phaedr., Itala; Mart. zo VII 20, 7. De genoemde Martialis-plaatsen staan in epigrammen, die meerdere popularismen bevatten. Van cirrus afgeleid is het ook bij Martialis (IX 29, 7; X 62, 8) voorkomende cirratus.

Clancularius: secundair gevormd van het ongetwijfeld familiaire deminutivum clanculum (v. clam). Het suffix -arius kan het familiaire karakter nog verhoogd hebben. Martialis heeft het X 3, 5 (chol.!), dus in een gedichtje met meerdere popularismen.

Coleus: DEL s.v. „mot populaire”. Het wordt gebezigd door Laber. mim., Cic. ep., Priap., Petron., Carm. epigr.; Martialis heeft het IX 27, 1 (chol.), omgeven door woorden als mentula, culus, draucus, penes; en (metonymisch van mensen) XII 83,2 . Ook in de Romaanse talen is dit woord overgegaan.

Comissator, comissatio: afgeleid van het meer populaire

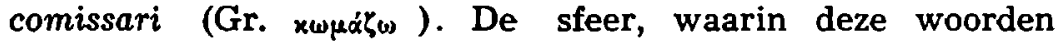
thuis horen, wordt duidelijk getekend door Mart. IV 5, 3 qui nec leno potes nec comissator haberi. Verder nog in V 16, 9; IX 61,15 ; XII 48,11 . Of comissatio wel echt populair is, waag ik te betwijfelen; het zal wellicht ook tot de meer beschaafde omgangstaal behoord hebben. (Cic., Suet., Sen.)

Crepare: DEL s.v.: „s'est même dit à basse époque (et sans doute dans la langue populaire) des êtres vivants." Dit geldt zeker voor Mart. XII 77, 11, waar crepare =pedere ,een wind laten" (dit verbum staat in het voorafgaande vers: variatio!).

Cris(s)o: Mart. X 68, 10 en XIV 203, 1: sensu obsceno. DEL neemt een onderscheid aan tussen crissare, dat van vrouwen gezegd wordt, en cevere, voor mannen gebruikt. Martialis handhaaft dit onderscheid. Het is een vulgair woord, dat voorkomt bij satirici en in priapea; de geminata is expressief.

Culus: DEL s.v.: „mot populaire (satiriques, graffiti, priapées)". Martialis heeft het 16 maal. 
Cunnus: behoort tot dezelfde sfeer als het vorige. Volgens Cic. kan men het beter niet gebruiken (vgl. DEL s.v.) Martialis heeft het zelfs 27 maal, en het ervan afgeleide cunnilingus (eveneens vulgair) 4 maal.

Emungere: komt reeds bij Plautus voor en wordt door Martialis in een vlot geschreven schets (VII 37,1) gezegd van een quaestor (!), die geen kans krijgt zijn druppende neus schoon te maken, een handeling, die even tevoren door exprimere wordt aangeduid.

Exhilare: we lezen dit verbum o.a. Cic. ad fam. 9, 26, 1, maar het komt toch vooral in de Keizertijd veel voor: Petron., Suet., Sen. dial., Colum., Cels., Plin. nat., Sil., post. (voornamelijk Christel.) : het is dus wel een woord van de beschaafde omgangstaal. Martialis heeft het VIII 50, 6.

Fellare: de geminata is expressief; zijn betekenis bestempelt het woord als vulgair. Martialis heeft het 11 maal, het afgeleide substantivum nog 5 maal.

Felix: de oorspronkelijke betekenis is "vruchtbaar". Volgens DEL s.v. is deze betekenis nog bewaard in de volkstaal van de Keizertijd. Zo Mart. I 49, 8 Pomona felix; XIII 20, 1 felicibus hortis; XIII 125, 1 felix vitibus; XIII 113, 1 felix Autumnus.

Festivus: komt vooral voor bij Plautus en in de postklassieke periode; Cic. heeft het alleen in zijn meer familiaire geschriften. Martialis schrijft het in de vlotte epigrammen VI 44, 1 en XII 45, 3 .

Focus: DEL s.v.: „dans la 1. popul., focus s'est substitué à ignis". Focus is overgegaan in de Romaanse talen, ignis daarentegen niet. In de betekenis „vuur" heeft Martialis focus in I 21 2; VI 73, 6; VIII 30, 8 (eerder in hetzelfde gedicht ook ignis, dus wel variatio); IX 31, 6; X 25, 2. Ignis heeft hij overigens nog op 15 plaatsen.

Fragrare: dit woord, vóór Catullus niet voorkomend, is poëtisch, maar is als expressieve uitdrukking ook binnengedrongen in de populaire taal; vandaar is het overgegaan in de Romaanse talen. Martialis heeft het 6 maal; een gezegde als basia fragrant (III 65, 9; XI 8, 12) en de plaats I 87, 1 (ruiken naar wijn) wijzen toch wel niet op de eerste plaats in de richting van een poëtisme bij Martialis.

Fricare: wanneer DEL s.v. aanneemt, dat dit woord tot de volkstaal behoort, geldt dit toch zeker voor Mart. XI 29, 8, 
waar het tegen een obscene achtergrond geplaatst wordt: nil opus est digitis: sic mihi, Phylli, frica.

Futuere: de betekenis en de geschiedenis van het woord (satirici, graffiti, priap.) wijzen duidelijk op het vulgaire karakter van deze uitdrukking, die bij Martialis niet minder dan 49 maal voorkomt, nog gesteund door fututio (1 maal), fututor (8), fututrix (adjectivisch gebruikt) (2).

Gabata: voor het eerst bij Martialis VII 48, 3; XI 31, 18. Blijkens DEL s.v. populair.

Galbinus: wordt alleen gelezen bij Petron., Mart., (2 maal; het afgeleide galbinatus 1 maal) en Juv.

Gannitus: afgeleid van het populair gekleurde verbum gannire. Het substantivum zal dus ook wel in dezelfde sfeer thuis horen, te meer waar we bij Martialis lezen V 60, 2 gannitibus improbis.

Garrire: een woord van de familiaire omgangstaal, voor het eerst bij Plautus, met expressieve geminata. Martialis heeft het 7 maal, het adi. garrulus 8 , garrulitas 3 maal (o.a. VII 18, 8 cunni garrulitate!)

Glaber: is volgens DEL een technische term of familiair. Martialis heeft het alleen XII 38, 4; bij hem lezen we voorts IV 28, 7 vae glabraria, vae tibi misella. Reeds het uiterlijk van het woord glabraria doet niet erg elegant aan; de toon van het gehele gedicht en de verbinding met het deminutivum misella spreken verder een duidelijke taal.

Hybrida: wordt gezegd van mensen en dieren. Het is een technische term met populair coloriet. Bij Mart. VIII 22, 2 tekent FRIEDLAENDER aan: „Vieleicht war hybrida als Schmähwort gebräuchlich." Dit zou het populaire element nog verhogen.

Immo: een exclamatie, die in de gesproken taal vaak een negatief antwoord inleidt ofwel een antwoord, tegenovergesteld aan het verwachte. Bij de comici vinden we het zeer vaak, in het algemeen bij de meer populaire auteurs, en dan voornamelijk in een levendige dialoog. Aldus ook bij Martialis op verschillende plaatsen. Het behoeft natuurlijk geen volkstaal-element te zijn.

Irrumare: Catull., Mart. (5 maal). De obscene betekenis karakteriseert het woord overigens reeds voldoende.

Iubere: volgens DEL s.v. is de betekenis van dit woord in de familiaire taal vaak verzwakt tot "uitnodigen, iets te doen, 
wensen", tenslotte is het zelfs gelijk geworden aan velle. Ook bij Martialis vinden we hiervan reeds enige voorbeelden: in VIII 14, 7 en XII 78, 2 is de betekenis practisch "wensen"; zeer duidelijk is overigens II 55, 1 vis te, Sexte, coli, waarop in vs. 2 volgt: quod iubes, colere. Hier staan velle en iubere duidelijk op één lijn; het is weer een van de vele gevallen van variatio.

Laecasin: een graecisme, dat we reeds lezen bij Petron. 42, 2 frigori laecasin dico. Dit is een wel zeer vulgaire uitdrukking. Bij Mart. is hiervoor van belang XI 58, 11 en 12 lota mentula laeva $\lambda_{\varepsilon: \chi \dot{\alpha} \zeta \varepsilon: v}$ cupidae dicet avaritiae. HERAEUS leest hier $\lambda_{\alpha}<x \dot{\alpha} \zeta \leq: v$, maar volgens FRIEDLAENDER ten onrechte; deze laatste wil ook de genoemde Petronius-plaats liever anders lezen: $\lambda_{\varepsilon i \chi \alpha} \zeta_{\varepsilon: \nu}$ (fellare) heeft hier meer zin dan $\lambda \alpha<x \dot{\alpha} \zeta_{\varepsilon i}, \quad$ (fornicari). Ik zou mij bij FRIEDLAENDER willen aansluiten, op grond van ecn volkomen eendere, cven vulgaire uitdrukking in sommige der huidige Limburgse dialecten.

Leno: dit woord, hoewel oud en ook wel bij Klassieke auteurs (Cic.) voorkomend, is toch vooral populair (weer het meermalen genoemde suff. -0 , -onis!). Martialis heeft het 3 maal, waarnaast hij ook het vrouwelijke lena (vgl. copo-copa) heeft in IX 29, 10.

Lepidus: dit woord, o.a. zeer geliefd door Catullus, floreerde in de omgangstaal van de republikeinse tijd. Zijn aanwezigheid bij Martialis (4 maal) kunnen we ofwel als een voortzetting hiervan beschouwen ofwel als een directe invloed van Catullus. Het subst. lepos heeft Martialis nog 2 maal. Uitvoeriger handelt hierover AXELSON p. 61. (Deze verbindt hiermee venustus, dat hij op dezelfde wijze karakteriseert. Venustus lezen we bij Martialis slechts één maal: XI 31, 20).

Lippus: een woord, dat met name tot de familiaire taal behoort; expressieve geminata. Martialis $(7$ maal) bezigt het meestal in gedichtjes, die reeds meerdere popularismen bevatten. Zo staat het in XII 59 temidden van woorden als basium, basiatus, fellator, cunnilingus, pilosus, hircosus, pediculosus.

Lupa: kan „wolvin” betekenen én „prostitué”. Bij Martialis vinden we beide betekenissen, resp. in II 75, 10 en I 34, 8 spurcas lupas (in obscene omgeving!)

Luscus: blijkens DEL s.v.: „mot populaire”. Martialis heeft het 13 maal, o.a. XII 70, 2 lusca anus, gezegd van een oud vrouwtje, dat in de badinrichting op de kleren past. 
Madere: is in de familiaire taal vaak gelijk aan ebrius esse. Deze laatste zin heeft het woord 2 maal bij Martialis (X 49,2 ; XI 15, 5), hoewel het in de meerderheid der gevallen (16) bij hem zijn gewone betekenis draagt.

Malleator: Mart. XII 57, 9. Afgeleid van het technischpopulaire malleus, dat bij Martialis overigens niet gevonden wordt. Ook hier weer de geminata!

Manima: een woord van de kindertaal, dat we bij Martialis 3 maal vinden voor "moeder", 5 maal in de betekenis "borst", dit laatste meerdere malen in populaire omgeving; zo III 72, 3 aut tibi pannosae dependent pectore mammae (het populaire pannosus wordt zo aanstonds besproken).

Mancre: volgens BAEHRENS p. 48 betekent dit verbum in de Culex (hij neemt aan. dat deze niet van Verg. is) „zijn, wonen". Bij Verg. en andere Augusteïsche auteurs komt deze bctekenis niet voor, maar wel in de volkstaal (vgl. Mansio-maison). Ook bij Martialis betekent manere gewoonlijk „blijven”. Er is echter één plaats, waar naar mijn mening de meer populaire betekenis aanwezig is, en wel VIII 14, 5 en 6 at cella datur, non tota clusa fenestra,/in qua nec Boreas ipse manere velit. Ik geloof, dat de vertaling "wonen" hier wel de beste zin geeft. Het feit, dat in het volgende vers habitare gebruikt wordt, kan deze opvatting nog verstevigen, daar een dergelijke variatio bij Martialis zeer gebruikelijk is.

Masturbari: Martialis heeft het 2 maal, masturbator 1 maal. Vanzelfsprekend zijn dit uitdrukkingen van de vulgaire taal.

Meiere: een verbum, dat gewoon is in de populaire taal: Catullus schrijft het voor het eerst; Martialis, die het 3 maal gebruikt, heeft o.a. deze aardige woordspeling III 78, 2 Meiere vis iterum? iam Palinurus eris ( $\pi \dot{a} \lambda \iota v$ objö̀v).

Mentula: dit woord is typerend voor de taal van Catullus en Martialis, en behoort zeker tot het populaire vocabularium. Blijkens DEL is de afleiding niet duidelijk, het staat dus ook niet vast, dat mentula een deminutivum is, reden waarom ik dit woord niet bij de deminutiva behandelde. Martialis heeft het op niet minder dan 49 plaatsen (overwegend in dactyli!)

Merda: zeker populair, zoals reeds de betekenis aanduidt. Martialis heeft het I 83, 2 en III 17, 6.

Moecha-moechus: resp. 14 en 15 maal bij Martialis voorkomend, behoren tot de populaire taal (comici, satirici). Het 
verbum moechari lezen we bij Mart. één maal; ook Catullus en Horatius schrijven het.

Mutuniatus: = magno pene praeditus. (Mart. III 73, 1 en XI 63,2). Afgeleid van muto, -onis = membrum virile, een woord, dat gelezen wordt bij Lucil., en Hor. en zeker populair, zoal niet vulgair is.

Narrare: kan, blijkens DEL s.v. gnarus, in de omgangstaal verzwakt zijn tot „zeggen". In dit licht bezien, krijgen de volgende Martialis-plaatsen een typische betekenis: in III 63, 2 vraagt Martialis sed quid sit, dic mihi, bellus homo? Wanneer hij dan het antwoord op zijn vraag ontvangen heeft, roept hij uit, vs. 13 Quid narras? hoc est, hoc est homo, Cotile, bellus? Opvallend is dus het op één lijn stellen van de beide, wel in omgangstaal gebruikelijke formules dic mihi en quid narras? Zo staat ook in V 29, 1 dicis, en in vs. 3, na de oratio recta: si verum, lux mea, narras. In XII 35, 2 staat dicere soles, vervolgd in vs. 4 door nam quisquis narrat talia. In elk van deze gevallen kan het streven naar variatio werkzaam geweest zijn. Vgl. overigens RUCKDESCHEL p. 84.

Natus: ad IV 83, 4 merkt FRIEDLAENDER op, dat ,nach dem Ausdruck des gewöhnlichen Lebens" aliquem natum non putare kan betekenen ,iem. als niet aanwezig, als lucht beschouwen." Dit gebruik van natus heeft Martialis op meerdere plaatsen. FRIEDLAENDER noemt hierbij ook XI 87, 2, waar hij in de tekst echter nota heeft opgenomen, een lezing van meerdere codices. G. FRIEDRICH p. 633 veronderstelt, dat natus in de omgangstaal diende ter vervanging van het ontbrekende participium praes. van esse. Als voorbeeld haalt hij aan o.a. IX 42, 11 nata est hostia, „das Opfertier ist da"; voorts VIII 64, 18; $\mathrm{X} 27,4$. Ook verwijst hij naar OTTO, Sprichw., waar vele voorbeelden van dit gebruik vermeld staan.

Nimis: betekent ook bij Martialis gewoonlijk „te veel, te zeer"; maar, DEL s.v., „à basse époque, dans la l. populaire, reparaît le sens de „beaucoup, très.” In dit laatste geval dient nimis dus practisch ter vervanging van de superlativus. DEL verwijst voor voorbeelden naar de Vulgata, maar ik ben met SCHNEIDER van mening, dat we reeds bij Martialis enkele voorlopers van deze omschrijving vinden (wellicht onder directe dwang van het metrum): I 87, 7 notas nimis; IX 89, 1 nimis dura; XII 38, 2 notus nimis.

Nubere: wordt normaal gezegd van de vrouw; het kan echter, zie DEL s.v., ook van de man gezegd worden, en wel a) 
in vulgaire taal (Pompon.); b) in Laat-Latijn (Tert., Vulg.); c) spottenderwijze. Dit laatste geldt zeker voor de Martialisplaatsen I 24, 4; VIII 12, 2 en XII 42,1. De mogelijkheid is echter niet uitgesloten, dat Martialis hiervoor bovendien steun vond in de omgangstaal.

Nugae: een woord van de omgangstaal, niet per se volkstaal. Martialis schrijft het op 20 plaatsen.

Paedicare: (is zeker vulgair (satirici, priapea). Bij Martialis vond ik het 18 malen; hiernaast het subst. paedico (-o, -onis!) nog 5 maal.

Pannus: is blijkens DEL s.v. familiair en wordt door Martialis II 46, 9 en X 5, 12 in peioratieve zin gebruikt. Typerend zijn de plaatsen, waar de afgeleide adiectiva gebezigd worden: III 72, 3 pannosae mammae en XI 46, 3 pannucea mentula.

Pantex, -icis: de gewone betekenis is (plur.) „darmen, ingewanden", soms ook ons volkswoord „pens". In deze laatste zin vinden we het bij Martialis in VI 64, 19.

Patrobas: ad II 32, 3 vermeldt FRIEDLAENDER: „Patrobas, familiaire Form von Patrobius."

Pedere: is vulgair (satirici) en verschijnt bij Martialis 6 maal; het van dezelfde stam gevormde podex, ook voorkomend bij Hor. en Juv., heeft onze dichter in II 42, 1 en VI $37,1$.

Penis: een woord, dat wegens zijn betekenis natuurlijk slechts zelden gebruikt wordt; is zeker populair. Martialis heeft het op 8 plaatsen, o.a. VI 23, 1 (in het volgende vers mentula: variatio). Vgl. ook IX 27.

Pera: voor het eerst bij Phaedrus overgeleverd, is, aldus DEL s.v., een ,terme populaire d'après $\mathrm{P}$ (aulus) $\mathrm{F}$ (estus) 249, 6." Martialis gebruikt pera op twee plaatsen, die karakteriserend zijn voor de populaire sfeer, waarin dit woord thuis hoort; in IV 53,3 staat het in de beschrijving van een philosoof, die volgens Martialis geen Cynicus meer is, maar een canis. Hetzelfde waarschijnlijk ook in XIV 81.

Pipinna: een uitdrukking, die ontleend schijnt te zijn aan de kindertaal, = parva mentula. Bij Martialis alleen XI 72, 1.

Popina: het populaire karakter van dit woord blijkt ook bij Martialis duidelijk uit de gehele sfeer, waarin het gebruikt wordt, zo V 70, 3; VII 61, 8 nigra popina; voorts nog op 3 plaatsen.

Prurire: Mart. III 58, 11 lezen we vitulus - prurit in pugnam. Hier heeft prurire practisch de betekenis van „verlangen, 
haken naar," dus zonder enige peioratieve bijbetekenis. Op 10 andere plaatsen echter wordt het gebruikt in sexuele zin, en dan vrijwel steeds in minder nette toespelingen. Vgl. o.a. I 35, 11; IX 90, 8. Ook het subst. prurigo heeft Martialis een maal in „gewone", 2 maal in sexuele betekenis (b.v. IV 48, 3 paenitet obscenae pruriginis?).

Pupa: oorspronkelijk met expressieve geminata geschreven; is ook een ontlening aan de kindertaal. Bij Mart. vinden we het IV 20, 1 en 2.

Quivis-quilibet: deze pronomina, door Verg., Tibull., Hor. carm., zo veel mogelijk vermeden, zijn volgens NEUMANN p. 41 speciaal eigen aan de omgangstaal; door de gegevens van AXELSON p. 75 wordt deze mening volkomen bevestigd. Ook bij Martialis zijn ze slechts schaars vertegenwoordigd, en wel quivis op 2, quilibet op 4 plaatsen: gezien de frequentie van de andere pronomina bij Martialis, is dit veelzeggend.

Rufus: een woord van dialectische oorsprong, dat in het Latijn slechts zelden voorkomt en volgens DEL s.v. een „couleur populaire ou technique" draagt. Het schijnt voornamelijk gelezen te worden bij Plaut., Ter., Cels., Vitr., Plin. en komt niet voor in het klassieke proza. In Mart. XIV 129 wordt het gebruikt om de kleur van Gallische kledingstukken aan te duiden en hier kan men het misschien in technische zin opvatten. De beide andere plaatsen, II 33, 2 cur non basio te, Philaeni?rufa es; en XII 32, 4 uxor rufa (minachtend) zijn daarentegen als populair te beschouwen.

Sandapila: een woord, dat pas in de Keizertijd schijnt opgekomen te zijn (Mart. 3 maal, Suet., Juv.) en in de populaire sfeer thuis hoort, zoals ook reeds zijn betekenis doet vermoeden: het duidt een draagbaar aan, die gebruikt werd voor de doden uit de lagere stand.

Saucius: de normale betekenis "gewond" vinden we bij Mart. sp. 12, 5 en XI 70, 4. In de omgangstaal schijnt het ook ter omschrijving van het begrip ,dronken" gediend te hebben. Ook hiervan biedt Martialis ons 2 voorbeelden: III 68, 5 en 6 Hinc iam deposito post vina rosasque pudore,/ quid dicat, nescit saucia Terpsichore; en IV 66, 12 incaluit quotiens saucia vena mero.

Scelus: DEL s.v.: „on trouve aussi dans la l.familière scelus avec le sens de „malheur, infortune.” Bij Martialis is dit laatste wel uitzondering, maar ik meen toch in VII 14, 1 accidit 
infandum nostrae scelus, Aule, puellae een voorbeeld van dit gebruik gevonden te hebben. In de vertaling van IZAAC vind ik sleun voor deze opvatting.

Scopae: (meestal plur.) is blijkens DEL s.v. „ancien (Naev., Cat.), technique et familier." Uit Mart. XIV 82, het geschenk van een arme betreffende, zou men kunnen opmaken, dat het gebruiken van een bezem in tegenstelling tot het in dienst hebben van een analecta, duidde op een minder goede welstand. Hierdoor ging het woord scopae blijkbaar over in de populaire sfeer.

Scriblita: behoort zeker tot de omgangstaal; we lezen het alleen bij Cato agr., Plaut., Petron., en Mart. III 17, 1 (in dit gedichtje komen voorts nog woorden voor als bucca, merda, gula!).

Sed: heeft bij Martialis vaak zijn adversatieve betekenis verloren en leidt dan een zin in, die een nadere verklaring van het voorafgaande geeft; we kunnen het dan vertalen door ,en wel." Dit typische gebruik is wel aan de omgangstaal ontleend (LöFSTEDT, Komm. Peregr. p. 180; BERTSCHINGER p. 38; FRIEDLAENDER ad I 117, 7; deze laatste geeft nog 12 voorbeelden uit Martialis).

Somnium: in de hogere taal ontwikkelde zich hiernaast wellicht naar het Grieks évínviov, insomnium; somnium zou dan, blijkens DEL s.v. somnus, een degradatie hebben ondergaan. Misschien vinden we de weerslag hiervan in Martialis, die insomnium nergens heeft, wel somnium VII 54, 1; overigens is dit slechts één plaats, die bovendien nog weinig overtuigend is, daar dit gedichtje verder geen uitgesproken popularismen bevat.

Stare: blijkens RUCKDESCHEL p. 152 is de gedeeltelijke verdringing van esse door stare, vooral in het Laat-Latijn frequent, reeds vroeg opgetreden; hij vond bij Lucr. reeds een enkel voorbeeld, waarbij zich dan aansluiten Hor. sat., en Petron. Ook noemt hij voor Martialis XII 94, 2 cessi, aemula ne starent carmina nostra tuis. Wellicht is dus ook hier weer een beïnvloeding van de zijde der omgangstaal aanwezig.

Stertere: behoort tot de omgangstaal (het komt reeds bij Plaut. voor), maar is in Laat-Latijn verdrongen door runcare; dit laatste echter niet bij Martialis. In populaire omgeving (soms zelfs obsceen) vinden we stertere bij Mart. III 82, 29; VII 10, 6; XI 104, 15. 
Strophae: is, gezien de auteurs, waarbij het gelezen wordt, blijkbaar een woord van de omgangstaal: Sen. ep., Mart. (III 7, 6; XI 7, 4), Phaedr., Plin. ep., post.

Tata: kan practisch op één lijn gesteld worden met mamma, zoals Mart. dan ook doet in I 100, 1.

Tisana: dit populaire woord werd reeds in het eerste hoofdstuk besproken. Varro heeft het voor het eerst; Mart. XII 72, 5.

Tomac(u)lum: kwam eveneens reeds eerder ter sprake. Het is zeker populair (satirici: Petron.) Het epigram, waarin Martialis het gebruikt, I 41, 9, beschrijft echte volkstypen, waardoor de sfeer, die dit woord omgaf, duidelijk gekarakteriseerd wordt

Tricae: komt voor bij Plaut., Turpil., Varro, Cic. ep., Petron. en is dus zeker populair. Martialis schrijft XIV 1, 7 sunt apinae tricaeque et si quid vilius istis, hetgeen reeds veelzeggend is. Zie ook onder apinae.

Unctus: kreeg in de omgangstaal de bijbetekenis „rijk, goed voorzien"; aldus vinden we het bij Plaut., Hor. ep., Pers., Petron., Mart. V 44, 7, Juv. Op de overige plaatsen draagt het bij Martialis echter zijn eerste betekenis. Vgl. RUCKDESCHEL p. 72.

Vappa: komt niet voor in het klassieke proza, wel bij Catull., Hor. sat., Priap.; vgl. RUCKDESCHEL p. 66. Hieraan kan men nog toevoegen Mart. XII 48, 14 perfida vappa.

Vapulare: roept direct de sfeer van de comedie op en hoort wel in de omgangstaal thuis. Martialis heeft het meerdere malen.

Verpa: = membrum virile, is een typisch woord van de satyre en de priapea. Martialis heeft het XI 46, 2, te midden van meiere, arrigere, pannuceus, mentula, anus, e.a. Verpus lezen we meerdere malen in XI 94 (waarin o.a. ook paedicare), en in VII 82, 6 (voorts nog penis, grandis, in unum).

Vispillo: weer een vorming op -o, -onis, komt alleen in de Keizertijd voor (Suet., Mart. 4 maal) en was eigen aan de omgangstaal (DEL s.v. vespa). 


\section{HOOFDSTUK III}

\section{De Syntaxis}

\section{§ 1: HET VERSCHOVEN PLUSQUAMPERFECTUM.}

Meerdere auteurs, o.a. E. LöFSTEDT (Komm. Peregr. ad 5, 10), KüHNER-STEGMANN (Gramm. Lat. Spr. II, 1 p. 140 vv.), WACKERNAGEL (Vorl. ü. Synt. I², p. 190), SCHMALZ-HOFMANN (Synt. p. 562), SCHRIJNEN-MOHRMANN (Stud. z. Synt. II p. 39 vv.) behandelen het bovenstaande onderwerp; de meesten van hen verwijzen naar het desbetreffende werk van $H$. BLASE, waarin we de geschiedenis van dit verschijnsel zeer uitvoerig beschreven vinden. De gegevens, gebruikt door de zo-even genoemde auteurs, komen practisch steeds met die van BLASE overeen, berusten daar trouwens merendeels ook op, maar in de verklaring van deze eigenaardigheid lopen de meningen uiteen.

Het plusq. perf., het praeteritum van de perfectum-stam, wordt als zodanig nooit absoluut gebruikt, maar duidt steeds het relatieve tijdsverschil aan (BLASE p. 107). Hiernaast zien we echter, dat het plusq. perf. reeds enkele malen in het OudLatijn, maar toch vooral in de latere perioden, ook afwijkend van deze grondregel gebruikt werd, en wel in die zin, dat het in betekenis niet verschilt van het imperfectum of perfectum. In deze gevallen is er dus sprake van een z.g. „verschoven” plusq. perf. Van deze verschuiving vinden we reeds enkele sporen bij Plautus ${ }^{20}$ ) en Terentius; zeer gering is de frequentie ervan bij de klassieke auteurs (bij Cicero practisch alleen in de brieven); maar in de post-klassieke periode breekt dit verschijnsel door en wordt in bepaalde gevallen zelfs regel, zodat in meerdere Romaanse talen duidelijk de sporen ervan aanwezig zijn. ${ }^{21}$ )

Hoewel ik nadere bijzonderheden hier gevoeglijk achterwege

20) Volgens BRIX-NIEMEYER, ad Capt. 17, zouden bij Plautus reeds 19 gevallen van deze verschuiving te vinden zijn, welk aantal echter door BLASE p. 22vv. op deugdelijke gronden gereduceerd wordt.

21) Zie BLASE p. 5; MEYER-LliBKE par. 115: „Speziell die wenig zahlreichen altfr. Fälle des Plusquamperfektums weisen durchaus perfektische Bedeutung auf. - - Auch im Spanischen und Portugiesischen findet sich vereinzelt diese Verschiebung". 
kan laten (ik verwijs hiervoor naar BLASE), zal men, met BLASE, gemakkelijk tot de conclusie komen, dat we in deze tempus-verschuiving een tendenz van de omgangstaal, en met name van de volkstaal dienen te zien. Zo zegt BLASE, o.a. op p. 36: „-, so hat sich ergeben, dasz selbst Cicero und seine hochgebildeten Korrespondenten sich nicht völlig dem Einflusse der Volkssprache haben entzjehen können, in der, wie wir annehmen, schon zu Plautus' Zeit die Verschiebung von fuerat teilweise durchgeführt war". En op p. 47, naar aanleiding van het gebruik van het plusq. perf. door Vitruvius: „Die vulgäre Unterströmung, die in der Sprache der Klassiker kaum hervorragte, tritt hier mächtig heraus." Trouwens, reeds a priori konden we hier invloed van de omgangstaal aannemen. H.H. JANSSEN (Rom. Dichtertaal p. 24) wijst er op, dat syntactische afwijkingen, die de structuur van de taal aantasten, in de regel niet uitgaan van de literaire taal, maar van de omgangstaal. Welnu, het verschoven plusq. perf. tást de structuur van de Latijnse taal aan, en wel in de tempus-leer!

Zoals reeds gezegd, lopen ten aanzien van de verklaring van deze tempusverschuiving de meningen nogal uiteen. BLASE zoekt het ontstaan ervan in een z.g. „Kombinationsausgleichung", een contaminatie, met als psychologische achtergrond een associatie: bij de spreker, zich voor het geval geplaatst ziende een praeteritum te moeten gebruiken, dringen de beide vormen fui en eram naar voren, waaruit, als "Sprechakt", de vorm fueram ontstaat. Zeer bevredigend is deze verklaring niet, daar het resultaat van een dergelijke contaminatie een vorm is, die ook zonder dit proces reeds bestond en een bepaalde functie te vervullen had in het Latijnse tempus-systeem.

Anderen gaan uit van de oorspronkelijke betekenis van de W. * fu- "ontstaan, worden", en zien dan als eigenlijke betekenis van fueram: ,ik was ontstaan: ik was er". En weer anderen leggen de nadruk op het (in de volkstaal geliefde) grotere klankvolume of op de metrische geschiktheid van fueram; deze redenen kunnen het gebruik van het verschoven plusq. perf. wel bevorderd hebben, een verklaring geven ze echter niet. Deze zullen we dieper moeten zoeken (vgl. SCHRIJNEN-MOHRMANN, II p. 40, die menen, dat wellicht meerdere motieven geleid kunnen hebben tot het schrijven van een plusq. perf. in plaats van een eenvoudig praeteritum). Een belangrijk motief kan geweest zijn het streven naar grotere duidelijkheid, een streven, dat vooral in de omgangstaal bestaat. Het is dan ook 
wel niet juist om, met LöFSTEDT, uit te gaan van de vorm dixerat, of van enig ander werkwoord. Van belang is echter wel de mededeling van LöFSTEDT (Komm. Peregr. p. 155 v.v.), dat deze verschuiving, hoewel niet uitsluitend, dan toch wel in de meeste gevallen wordt aangetroffen in relatieve zinnen.

Hoe staat Martialis nu tegenover een dergelijk gebruik van het plusq. perf.? BLASE, die toch zeer veel Latijnse auteurs in zijn onderzoek betrekt, geeft niet één voorbeeld uit Martialis, noemt zelfs de naam van onze dichter nergens, terwijl, zoals we zullen zien, Martialis toch voorbeelden te over biedt, die hem zeer zeker vermeldenswaard maken. Ook hier dus weer een jammerlijk gevolg van het feit, dat aan de taal van Martialis tot nu toe te weinig aandacht werd geschonken. Toch was het zelfs FRIEDLAENDER, die in zijn commentaar overigens zelden linguistische bijzonderheden vermeldt, reeds opgevallen, dat Martialis op meerdere plaatsen het plusq. perf. in van de klassieke norm afwijkende zin gebruikt. Bij I 107, 3 (fecerat) tekent hij n.l. aan: „M. neigt zum Gebrauch des Plusquamperfekts, wo man das Perfekt (oder auch das Imperfekt) erwartet, namentlicht feceram, fueram, dixeram. Vgl. z. B. II 41,2;II 83, 2; III 52, 1; V 52, 4; V 23, 1; XI 37, 3; XI 39, 12; XI 71, 1; XI 99, 9; XII 60, 4." Dit zijn dus reeds elf plaatsen, waarvan er echter één, n.l. II 83,2 , m.i. niet overtuigend is, terwijl XI 99,9 niet bestaat.

Een goed voorbeeld is ook I 30, 1: Chirurgus fuerat, nunc est vispillo Diaulus. H. J. IZAAC vertaalt hier: „Dialus était chirurgin: il s'est fait croque-mort."

Zo ook het begin van II 41:
"Ride, si sapis, o puella, ride"
Paelignus, puto, dixerat poeta:
sed non dixerat omnibus puellis.
Verum ut dixerit omnibus puellis, non dixit tibi: tu puella non es.

En de vertaling van IZAAC luidt: „Ris, si tu es avisée, ô jeune beauté, ris". Ainsi s'est exprimé le poète pélignien, si je ne me trompe; mais il ne l'a pas dit pour toutes les jeunes femmes, et en admettant même qu'il l'ait dit pour toutes les jeunes femmes, il ne l'a pas dit pour toi: toi, tu n'es pas une jeune femme.

Opvallend is, dat Martialis hier in de verzen 2 en 3 dixerat gebruikt, en in vers 5 , in precies eendere zin, dixit. Instructief is voorts VIII 74:

Oplomachus nunc es, fueras ophthalmicus ante: fecisti medicus quod facis oplomachus. 
Dus in het eerste vers praesens en plusq. perf. naast elkaar, in het tweede daarentegen praesens en perfectum, terwijl in beide verzen de tijden toch op één lijn staan.

VII 61, 4: et modo quae fuerat semita, facta via est. -" En wat zo even nog een voetpad was, is nu een weg geworden". (Zo ook IZAAC). ${ }^{22}$ )

Het zou te ver voeren, alle desbetreffende plaatsen hier volledig uit te schrijven. Ik wil dan ook volstaan met het opsommen van die plaatsen, waar we, naar mijn mening, te doen hebben met een verschoven plusq. perf.

\begin{tabular}{|c|c|c|c|c|c|}
\hline \multicolumn{2}{|c|}{ plaats } & versmaat & vorm & \multicolumn{2}{|c|}{ aard v. d. zin } \\
\hline $\mathrm{sp}$ & 28,1 & $\mathrm{~d}$ & fuerat & $\mathrm{H}$ & $\left.{ }^{24}\right)$ \\
\hline 1 & 19,1 & d & fuerant & $\mathrm{H}$ & \\
\hline 1 & 30,1 & $d$ & fuerat & $\mathbf{H}$ & \\
\hline & 47,2 & $d$ & fecerat & $\mathrm{H}$ & \\
\hline & 107,3 & d & fecerat & - & \\
\hline II & 41,2 & hend & dixerat & $\mathbf{H}$ & \\
\hline I] & 41,3 & hend & dixerat & $\mathrm{H}$ & \\
\hline I) & 63,1 & d & fuerant & $\mathrm{H}$ & \\
\hline II & 64,4 & d & fuerat & $\mathrm{H}$ & \\
\hline III & 24,13 & d & fueras & - & \\
\hline III & 70,2 & d & fuerat & - & \\
\hline III & 93,22 & chol & vocaverat & - & \\
\hline V & 52,4 & d & dixerat & $\mathbf{H}$ & \\
\hline VII & 37,4 & $\mathrm{~d}$ & iusserat & $\mathrm{H}$ & \\
\hline VII & 57,2 & d & fuerat & $\mathrm{H}$ & \\
\hline VII & 61,4 & $d$ & fuerat & - & \\
\hline VII & 94,1 & $\mathrm{~d}$ & fuerat & $\mathbf{H}$ & \\
\hline VIII & 16,1 & hend & fueras & - & \\
\hline VIII & 74,1 & d & fueras & $\mathrm{H}$ & \\
\hline $\mathrm{IX}$ & 45,2 & $\mathrm{~d}$ & tuleras & $\mathrm{H}$ & \\
\hline $\mathrm{X}$ & 79,9 & d & ruperat & - & \\
\hline XI & 5,2 & d & fuerat & - & \\
\hline $\mathrm{XI}$ & 37,3 & d & fuerat & $\mathrm{H}$ & \\
\hline $\mathrm{XI}$ & 39,1 & d & fueras & $\mathrm{H}$ & \\
\hline XI & 39,12 & $d$ & fecerat & $\mathrm{H}$ & \\
\hline XI & 71,1 & d & dixerat & $\mathrm{H}$ & \\
\hline XIII & 46,1 & d & fueramus & $\mathrm{H}$ & \\
\hline
\end{tabular}

22) Vgl. o.a. VIII 65, 1 en 2: Hic ubi Fortunae Reducis fulgentia late/templa nitent, felix areanuper erat.

23) $d=$ dactyli; hend $=$ hendecasyllabus; chol $=$ chollambus.

24) $\mathbf{H}=$ hoofdzin. 
De reeks van voorbeelden, door FRIEDLAENDER gegeven, is hiermee dus aanzienlijk uitgebreid. Men zal misschien in enkele gevallen kunnen disputeren over de juistheid van mijn tekstinterpretatie, omdat, juist in een kwestie als deze, ook het subjectieve inzicht een bepaalde, hoewel niet doorslaggevende rol speelt, ${ }^{25}$ ) maar dan dient men toch te bedenken, dat voor de ontwikkeling van een dergelijk verschijnsel ook de twijfelgevallen hun betekenis heben, terwijl zelfs afgezien van deze gevallen er toch voorbeelden te over aanwezig blijven, om te mogen concluderen, dat Martialis in zijn omgangstaal het verschoven plusq. perf. gebruikt heeft en het bewust of onbewust, - dit doet niet ter zake -, ook in zijn gedichten heeft opgenomen.

Overzien we het bovenstaande nog eens, dan valt allereerst op, dat het merendeel van de gevallen (23) voorkomt in dactyli, terwijl slechts enkele in hendecasyllabi (3) en choliamben (1) gevonden worden, in welke laatste versmaten we toch vooral een dergelijk populair verschijnsel zouden verwachten; hierbij moeten we echter bedenken, dat een vorm als fuerat voor dactyli bijzonder geschikt is, in hendecasyllabi minder mogelijkheden heeft, en voor choliamben practisch onbruikbaar is; dit wordt bevestigd door het feit, dat de enige plaats in choliamben de vorm vocaverat betreft. Zijn dus enerzijds de quantiteitsverhoudingen van de diverse versmaten wel van dwingende betekenis voor de keuze van een bepaald woord of een bepaalde vorm, dan is toch anderzijds de qualiteit ervan voor Martialis niet beslissend voor het al dan niet toelaten van popularismen.

Voorts zien we, dat fuerat (en andere personen) 16, dixerat 4, fecerat 3 , en vocaverat, iusserat, tuleras, ruperat elk 1 maal voorkomen. In het merendeel van de gevallen past Martialis de verschuiving dus toe bij die verba, die ook bij de auteurs vóór hem het meest aan dit verschijnsel onderhevig waren. Dat habuerat, - een vorm, die, getuige BLASE, in deze toch ook een belangrijke rol speelt, - bij Martialis niet voorkomt, hangt natuurlijk samen met de onbruikbaarheid van deze vorm voor Martialis' metra.

Dat het in 19 van de 27 genoemde gevallen hoofdzinnen zijn, waarin de verschoven plusquamperfecta voorkomen, is bevreemdend; ook al houden we er rekening mee, dat Martialis, zoals in de desbetreffende § zal worden aangetoond, zeer vaak

25) Het is om deze reden, dat ik meerdere plaatsen niet heb vermeld, b.v. VIII 50, 6; IX 70, 1 . 
de voorkeur geeft aan de paratactische constructie boven de hypotactische, zodat dus bij hem een grammaticale hoofdzin daarom nog niet de hoofdgedachte behoeft te bevatten, dan blijft de verdeling in deze nog opvallend. Martialis is in het gebruik van het verschoven plusq.perf. dus verder gegaan dan vele andere auteurs.

Tot slot nog een enkele opmerking over de vorm credideram, bij Martialis voorkomend in I 42, 4 (dact./hoofdzin) en VII 82, 3 (dact./hoofdzin); BLASE p. 75 zegt hierover het volgende: ,Ebensowenig gehört crediderant in den Rahmen unserer Verschiebung. Credidi hat schon im klassischen Latein die Bedeutung ich glaube." Deze uitspraak van BLASE wordt niet overgenomen door SCHMALZ-HOFMAN p. 560: hier wordt invloed van novi, noveram aangénomen. Overigens komt dit verschijnsel speciaal voor in het Laat-, en dan met name Christelijk Latijn. Vgl. SCHRIJNEN-MOHRMANN II p. 16 vv. Bij Martialis echter kunnen we invloed van novi aannemen, waarbij de tendenz van het verschoven plusq.perf. kan meegewerkt hebben. Aldus zou men de beide plaatsen met credideram nog kunnen toevoegen aan de eerder gegeven lijst.

\section{PARTICIPIUM PERF, PASS. + FUI, ETC.}

In deze $\S$ dient ook een ander verschijnsel besproken te worden, dat met het zo-even behandelde weliswaar nauw verbonden, maar toch niet op één lijn te stellen is; ik bedoel de verbinding van het part. perf. pass. (of depon.) met fui, fueram, fuero, fuisse voor sum, eram, ero, esse. BLASE (p. 59) heeft dit verschijnsel in een afzonderlijke $\S$ behandeld, maar door LEUMANN (zie literatuurlijst) is de opvatting van BLASE in deze achterhaald (vgl. ook SCHRIJNEN-MOHRMANN, II p. 29 vv.).

A. Het type locutus fui (tegenover - sum) wordt, blijkens SCHMALZ-HOFMANN p. 562, pas frequenter sinds de 7e eeuw, hoewel duidelijke voorbeelden, zij het zelden, toch ook wel eerder worden aangetroffen, zo bij Vitruv., Flor. epit., Justin., Gell., e.a. Volgens LEUMANN p. 192 is locutus sum in het (vulgaire) latere Latijn regel, zowel in hoofd-, als in bijzinnen; locutus fui blijft een uitzondering. Martialis nu biedt ons zelfs 7 voorbeelden van het type locutus fui:

I 43,1 fuimus vocati.

VI 88, 4 missa fuit.

IV 76,2 credita fuere. IIIV 77, 8 data fuit.

IX 56, 7 fuit laesus.

IX 59, 16 fuerunt nobilitata.

XIV 35, 2 empta fuit. 
Deze voorbeelden staan zowel in hoofd-, als in bijzinnen; ook bij Martialis is echter locutus sum de normale vorm.

B. Het type locutus fueram (tegenover - eram) komt volgens LEUMANN meestal voor in relatieve zinnen; zo althans is de regel voor het latere Latijn, hoewel dit ook voor Livius reeds schijnt te gelden. Bij Martialis, voor wie locutus eram de normale vorm is, vinden we toch ook enkele voorbeelden van locutus fueram, en wel:

I 82,5 (hend.) gestatus fuerat "2)

III 52, 1 (dact.) empta fuerat (H).

$\mathrm{V} \mathrm{23,} 1$ (dact.) fueras indutus $(\mathrm{H})$.

VI 15, 3 (dact.) fuerat contempta (rel. zin). VIII 33, 3 (dact.) fuerat perunctum (H).

XII 60, 4 (dact.) fueras cultus (rel. zin).

Al staat hiernaast een meerderheid van eram, toch kent en gebruikt Martialis de vorming met fueram, en wel overwegend in dactyli; het is echter opvallend, dat de constructie met fueram bij Martialis slechts 2 maal in een relatieve zin staat, en viermaal in een hoofdzin!

Uit genoemde plaatsen blijkt, dat hier niet de keuze van het plusq. perf. als zodanig verkeerd is, zodat we, althans in deze zin, hier niet met een verschoven plusq. perf. te doen hebben, maar dat de wijze, waarop het plusq. perf. gevormd is (dus fueram i.pl.v. eram), afwijkt van de klassieke normen. Het is dus onjuist, wanneer BLASE zegt (p. 59) : „So ziehe ich denn die Annahme vor, dasz auch hier einfach Ersatz von eram durch verschobenes vulgäres fueram vorliegt." Waarschijnlijk is het streven naar grotere duidelijkheid hier werkzaam.

C. Het type locutus fuero is, volgens LEUMANN p. 193, als het ware gereserveerd voor de conditionele, hypotactische zinnen. Hoewel deze regel weer geldt voor het latere Latijn, blijken ook vroeger hiervoor reeds enkele voorbeelden gevonden te worden. Bij Cyprianus staat locutus fuero meestal in een si-zin, maar toch ook, zij het minder vaak, in andere bijzinnen

26) Het gehele vers luidt: gestatus fuerat recesseratque. De beide plusquamperfecta zijn hier op hun plaats, maar het eerste is ,verkeerd" gevormd. In het volgende vers staat cum repente (cuminversum); de grammaticale hoofdzin bevat in feite dus niet de hoofdgedachte van de zin. Men vergelijke hiernaast I $12,8 \mathrm{cum} \ldots . . \mathrm{g}$ estatus bi i g is Regulus esset equis, waar het plusquamper. fectum dus goed gevormd is, hoewel hier misschien het feit van belang is, dat we op deze plaats te doen hebben met een coniunctivus, voor welke modus ik bij Martialis geen cnkel voorbeeld vond van het type locutus fuissem. 
(SCHRIJNEN-MOHRMANN, p. 34). Martialis biedt ons slechts één voorbeeld, en wel IX 56, 9 quisquis ab hoc fuerit fixus morietur amore. Hier staat fuerit dus niet in een si-zin, maar de betekenis is toch zeker conditioneel. (Vgl. Cyprianus, Ep. 68, 3 quisquis ingressus fuerit). ${ }^{27}$ )

D. Het type locutum fuisse blijkt weer gewoon te zijn in het latere Latijn, waarnaast - esse slechts zelden voorkomt. (LEUMANN p. 193). Bij Martialis vond ik deze ene plaats: VIII 51, 10 vecta fuisse.

Kort samengevat kunnen we dus zeggen, dat Martialis ten aanzien van de verbinding van het part. perf. pass. met fui etc. ons meerdere malen verrast; het meest opvallend is wel het gebruik van het type locutus fueram in hoofdzinnen!

\section{§ 2: DE VRAAGZINNEN.}

In de oudsle taaltoestand werden de vragende zinnen slechts gekenmerkt door een eigen zinsaccent, dat bestond in een verhoging van de stemtoon op het einde van de zin; pas in latere tijd ging men vraagpartikels gebruiken, terwijl we, wat het Latijn betreft (de voorafgaande opmerkingen gelden in het algemeen), in de omgangstaal en met name ook in de periode van de latere Latiniteit weer steeds meer vraagzinnen, niet ingeleid door een partikel, aantreffen, vooral in affectief-gekleurde taal. KüHNER-STEGMANN (Satzlehre II pag. 501 vv.) leert ons, dat vraagzinnen zonder partikel voorkomen:

a) Wenn überhaupt eine Antwort verlangt wird, so sehr häufig in der vorklassischen Zeit, besonders bei Plautus, in der klassischen Zeit selten, häufig bei Späteren.

b) Wenn die Frage mit einem gewissen Affekte, namentlich der Verwunderung, des Unwillens, der Verhöhnung, des Tadels ausgesprochen.... wird.

Men zou dus kunnen zeggen, dat in deze omstandigheden de taal teruggevallen is in haar "primitieve" toestand.

P. BRODMUEHLER geeft ons een zeer duidelijk beeld

27) Martialis gebruikt meerdere malen een futurum exactum in de betekenis van een gewoon futurum; dit verschijnsel kunnen we reeds in het Oud-Latijn waarnemen en het is, met name in de volkstaal, blijven voortleven. Hier kunnen we dus moeilijk spreken van een tempusverschuiving. Vgl. SCHMALZ-HOFMANN, p. 564 en SCHRIJNEN-MOHRMANN $\Pi$ p. 43 vv. Bij Martialis lezen we op de volgende plaatsen $f u$ e $r$ it voor erit: II 16,2 ; VIII 9, 4; XIV 71,1 ; XIV 188,1 . 
van de stand van zaken in dit opzicht voor wat betreft de periode van de Zilveren Latiniteit. Zijn studie maakt de indruk een zeer nauwkeurig en zo volledig mogelijk, dus betrouwbaar, overzicht te geven van de vraagpartikels, gebezigd door Livius, Seneca, rhet., Vitruvius, Velleius Paterculus, Valerius Maximus, Celsus, Phaedrus, Seneca phil., Curtius Rufus, Columella, Scribonius Largus en Pomponius Mela. Martialis wordt echter niet behandeld, zelfs nergens aangehaald. Op pag. 1 van genoemd werk zegt BRODMUEHLER:

„In nulla vero re recentiores scriptores magis ab optima illa dicendi ratione dissentiunt quam in particularum usu. Namque numerus particularum magis magisque minuitur, maxime in sermone cotidiano, qui temporibus Plauti et Terentii particulis abundaverat".

We zullen zien, dat deze woorden door Martialis, meer wellicht dan door verschillende bij BRODMUEHLER wel behandelde auteurs, waar gemaakt worden. Ik heb de vraagzinnen bij Martialis, naar het voorbeeld van BRODMUEHLER, onderzocht, zodat het hier volgende overzicht - naar mijn mening is het volledig - kan gelden als een aanvulling bij genoemd werk (met dien verstande, dat ik niet, zoals BRODMUEHLER doet, alle desbetreffende plaatsen zal opgeven, daar dit, voor Martialis, te ver zou voeren), terwijl het ons tevens een verantwoord beeld geeft van Martialis' taalgebruik in deze. Duidelijkheidshalve heb ik de volgende indeling gemaakt:

Groep I A: Een-ledige Directe Vragen.

Groep I B. Disiunctieve Directe Vragen.

Groep II A: Een-ledige Indirecte Vragen.

Groep II B: Disiunctieve Indirecte Vragen.

GROEP I A: EEN-LEDIGE DIRECTE VRAGEN.

-ne.

Deze partikel wordt in de Keizertijd steeds minder gebruikt en vooral in de omgangstaal voortdurend zeldzamer. Hier hebben we te doen met een van de typische kenmerken van de Zilveren Latinitas. Martialis gebruikt -ne slechts vier maal, het laatst in boek VIII. Op enkele plaatsen vervangt het zeer duidelijk num, b.v.

I 10, 3: Adeone pulchra est? Immo foedius nil est. 
is, aldus KUEHNER-STEGMANN (pag. 516): „noch ziemlich selten bei den Komikern (und zwar bei Plautus nur vor Vokalen), häufig bei Cicero (bij Caesar slechts eenmaal!), selten bei Livius (6 maal), später von einzelnen Auctoren ganz gemieden". Met name ontbreekt deze partikel bij Catullus, Tibullus en zoals HOFMANN en HERAEUS ons leren - bij Martialis, bij welke auteurs we menig omgangstaal-element aantreffen.

Wel vinden we op enige plaatsen non in plaats van nonne:

IX 82, 6: Dic mihi, non hoc est, Munna, perire cito?

Zo ook V 82, 3 en IX 92, 12. Ditzelfde vinden we ook bij Phaedrus en Seneca rhet.

\section{num}

schijnt reeds in het begin van de Keizertijd uit het vulgaire Latijn verdwenen te zijn en vervangen door het (klankvollere) numquid; we vinden het dan ook nergens terug in de Romaanse talen.

Cicero (Att. 12, 8) (het betreft hier een indirecte vraag) bezigt numquid voor num; het gebruik wordt reeds talrijker bij Seneca rhet., bij welke auteur echter, volgens enkele codices, ook num voorkomt, welke partikel dan wellicht zal moeten vervangen worden door non. Opvallend is, dat dezelfde partikel ook bij andere auters (b.v. Martialis) moeilijkheden meebrengt!

Ook bij Phaedrus, Petronius, Seneca phil. en Columella vinden we numquid voor num, meestal in directe vragen en met negatieve betekenis.

Martialis heeft in een-ledige directe vragen numquid 17 maal in dactylische verzen, vijf maal in hendecasyllabi, nergens in choliamben, terwijl ten slotte in de overige versmaten nog slechts eenmaal numquid voorkomt; in totaal dus 23 plaatsen ${ }^{28}$ ). De betekenis is ook bij onze dichter meestal negatief; slechts op enkele plaatsen (b.v. V 58, 4) zou men het gelijk kunnen stellen aan -ne.

Hiertegenover staat, dat, volgens FRIEDLAENDER, num tweemaal voorkomt, STOLZ-HOFMANN vermeldt slechts één plaats als zeker, en W. HERAEUS betwijfelt zelfs van beide plaatsen de juistheid. De omstreden plaatsen zijn: 1) IV 27, 2 2) VIII 37, 2.

28) $\mathrm{n}$ u m q u id. I 34,$9 ;$ I 74,$2 ;$ I 106,$4 ;$ III 51,4 ; III 70,4 ; III 74,$2 ;$ V 58, 4; V 80, 7; VI 8,6 ; VI 12, 2; VI 32, 6; VII 15, 2 ; VII 16, 2; VII 50, 7; VIII 21, 3; DX 44, 4; X 26, 8; X 68, 10; X 75, 13; XII 1, 3; XII 42, 6; XIV 62, 1; XTV 121, 2. 
ad 1): de codices $\mathrm{Ba}^{\mathrm{a}}$ en $\mathrm{Ca}$ geven num; andere lezingen vinden we in sommige minder belangrijke codices. Misschien is het dan ook beter om num hier te handhaven, vooral daar het hier staat vóór minus, en volgens HOFMANN de verbinding num minus, bij meerdere auteurs voorkomend, geacht kan worden een vaste verbinding te zijn.

ad 2): num wordt in de codices van de Itali gelezen, wier betrouwbaarheid echter vaak betwijfeld wordt; $\mathrm{B}^{\mathrm{a}}$ heeft non, welke lezing, wegens de betekenis van het vers, onwaarschijnlijk is; cod. Ca geeft nunc, waarbij W. HERAEUS, wiens mening ik deel, aantekent: "fort. recte."

Samenvattend vinden we aldus, tegenover ecnmaal num, cen overwegen van het in de omgangstaal gebruikelijke numquid (23 maal), een meerderheid, die we slechts zclden zullen aantreffen bij andere auteurs.

\section{an,}

als inleidende partikel van een een-ledige directe vraag, is reeds in de gouden Latiniteit in gebruik en komt zo ook, geheel regelmatig, voor bij Curtius Rufus en Columella. Martialis biedt ons hiervoor tien plaatsen, o.a.

II 65, 2: „An causa levis est?” inquis.

Het antwoord is steeds, zoals ook in de Klassieke periode, tegenovergesteld aan de vraag. Soms gaat er een mededeling of veronderstelling vooraf, waarmede de vraagzin in tegenstelling staat (zie b.v. VIII 33,5). Hier is het gebruik van Martialis dus in overeenstemming met dat in de tijd van de gouden Latiniteit.

\section{ecquid.}

Het pronomen ecquis vinden we bij Martialis slechts in V 25, 3 en 4; het antwoord op deze vraagzinnen is, zoals uit de slotverzen van dit epigram blijkt, negatief. Het neutrum ecquid wordt door Martialis meerdere malen (6) gebruikt als vraagpartikel, hetgeen we ook bij andere schrijvers aantreffen: $\mathrm{Ci}$ cero gebruikt ecquid steeds in negatieve zin, dus practisch weer ter vervanging van num; zo ook Seneca rhet., misschien ook (slechts eenmaal) Phaedrus (vers onzeker). Zelden vinden we ecquid bij Seneca phil., en Curtius Rufus, met dien verstande, dat het bij deze laatsten soms staat voor num, soms voor -ne.

Met beide laatste auteurs stemt Martialis practisch overeen; 
bij hem is ecquid vier maal gelijk aan num (b.v. II 24, 5), twee maal aan -ne (b.v. VII 6, 1).

Het tot $\mathrm{nu}$ toe behandelde heeft betrekking op 44 vraagzinnen; hiernaast staat echter een veel groter aantal eenledige directe vragen, die $n$ i e $t$ door een partikel worden ingeleid. Deze laatste groep omvat namelijk bij Martialis 212 zinnen, en zo één schrijver dus in staat is de woorden van BRODMUEHLER, in het begin van deze paragraaf aangehaald, te bewijzen, dan toch zeker wel Martialis!

Als typisch en duidelijk voorbeeld kan men noemen:

V 16, 14: Dissimulas? - -

Zeer vaak vinden we vraagzinnen, waarin een demonstratief pronomen of adverbium is opgenomen, waardoor bij het voordragen van dergelijke verzen de intonatie, waarop de vraagkracht van deze zinnen toch reeds drijft, nog verlevendigd wordt, b.v.

III 63, 13: hóc est, hóc est homo, Cotile, bellus?

V 82, 3: Rogo, non est turpius istud?

In dit laatste vers (ook dit type komt bij Martialis menigmaal voor!) is de vraagzin niet afhankelijk van rogo, maar er paratactisch mee verbonden. Men zou zelfs kunnen zeggen, dat rogo in zekere zin dient om de lezer op de vraag opmerkzaam te maken, dus haast de functie van vraagpartikel vervult.

Behalve de bovenstaande typen zijn er nog enige, die telkens weer terugkeren bij Martialis. Ik noteerde de volgende:

A. Met quisquam b.v. V 20, 14:

Quisquam vivere cum sciat, moratur?

Van dit type vond ik vijf voorbeelden bij Martialis.

B I) Met quaeris + afhankelijke vraag; b.v.

II $31,1:-$. Det quam bene quaeris?

De hoofdzin heeft dus geen partikel. Dergelijke zinnen heeft Martialis 16 maal. (Soms ook het meervoud quaeritis.).

B 2) Idem met requiris; b.v.

$\mathrm{X}$ 102, 1: Qua factus ratione sit, requiris?

Dit type gebruikt Martialis 7 maal.

C. Met vis: + coniunctivus:

I 117, 2: „Vis mittam puerum?” subinde dicis. of + infinitivus:

II 53, 1: Vis fieri liber?

Dit type wordt zelfs 27 maal door Martialis gebruikt! 
Behalve de bovenstaande vraagzinnen ${ }^{28}$ ) behandelt BRODMUEHLER ook nog de zinnen, die ingeleid worden door de volgende vraagpartikels of formules:

A. „Waarom":

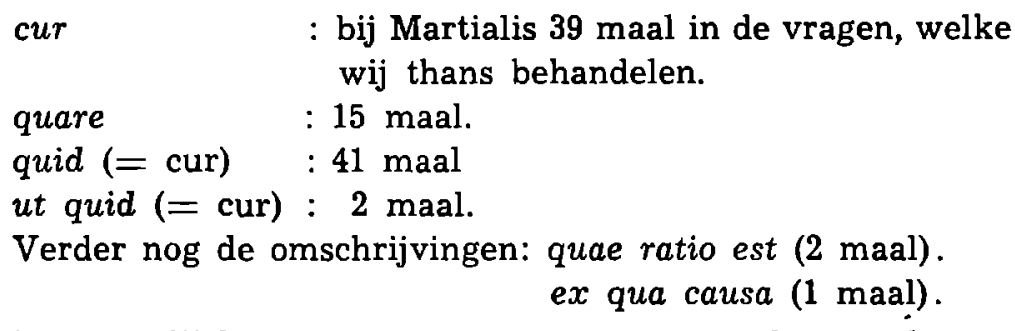

Het is wellicht dienstig enige gegevens uit het werk van BRODMUEHLER hier ter vergelijking aan te halen. Wij lezen daar op pag. 12: „Quid pro „cur" adhibitum ex sermone cotidiano assumptum esse videtur mihi, ubi saepe cum particula ita coniungitur". Uit het bovenstaande blijkt de frequentie van quid bij Martialis, al komt dit woord dan, practisch, even vaak voor als cur. Quid ita komt echter, naar mijn mening, niet voor bij Martialis; over deze formule deelt BRODMUEHLER ons mede, dat zij bij de comici zeldzaam is, in de periode van de gouden Latiniteit nog zeldzamer; in de zilveren Latiniteit wordt de frequentie eerst groter (b.v. bij Vitruvius en Val. Max.) maar later toch weer minder. Zou het ontbreken van quid ita bij Martialis misschien reeds een symptoom zijn van deze algemene teruggang? Ook bij Curtius Rufus ontbreekt quid ita geheel.

Ut quid (= „waarom") vinden we bij Martialis:

III 77, 10: Ut quid enim, Baetice, saprophagis?

XI 75, 2: - Ut quid, oro.

Zie ook VII 34, 8.

Deze formule wordt veelvuldig gebruikt door de „scriptores ecclesiastici" ( = iv $\tau$ $\tau$ ), o.a. door Augustinus en in de Vulgata.

B. „Hoe”:

$U t$ ontbreekt in de een-ledige directe vragen.

Quomodo: eenmaal.

Qua ratione: eenmaal.

29) Wanneer een auteur een directe vraag afhankelïjk maakt van een verbum dicendi, kunnen we zeker spreken van een ontlening aan de breedsprakige omg.taal (RUCKKD. p. 161). Een speciale vermelding verdienen dan ook Mart. $\mathrm{V} 10,1$ es se quid hoc dicam, quod...... en II 12, 1 . 
Hierbij kunnen we slechts aantekenen, dat Vitrivius quomodo vermijdt, en vervangt door quemadmodum. Overigens beschikken we in deze bij Martialis over te weinig materiaal, zodat het geen zin heeft er enige conclusie aan te verbinden.

Tenslotte dan nog enkele vraagpartikels, waarover HOFMANN (Umg. Spr.) handelt op p. 66, n.l. quid ergo, quid quod en quid si, welke alle behoren tot de omgangstaal. Ook Petronius gebruikt deze formules vaak en dan overwegend in de gesprekken der vrijgelatenen. De frequentie ervan bij Martialis wordt door het onderstaande schema weergegeven:

\begin{tabular}{lcccccc}
\hline formule & hexam. & pentam. & chol. & hend. & ep. & totaal \\
\hline quid ergo & 2 & 5 & 3 & 4 & - & 14 \\
quid quod & 5 & 1 & - & 1 & - & 7 \\
quid si & 1 & 2 & 1 & 2 & $\frac{1}{7}$ \\
\cline { 3 - 4 } & & & & & $\frac{7}{28}$
\end{tabular}

(quid ergo vinden we drie maal in omgekeerde lezing: ergo quid).

\section{B. DISIUNCTIEVE DIRECTE VRAGEN.}

Bij deze groep van vraagzinnen, bij Martialis in veel geringer mate vertegenwoordigd dan de vorige, kunnen we de volgende indelingen maken:

A. Type ne-an (d.w.z. in het eerste lid -ne, in het tweede an): hiervan is slechts een voorbeeld aan te wijzen: IV 11, 5 vv.

B1) Type - - an (het eerste lid heeft geen partikel, het tweede lid heeft an) : b.v. III 88, 2: Dissimiles sunt magis an similes? Dit type, dat volgens BRODMUEHLER 24 maal voorkomt bij Celsus, is bij Martialis 8 maal vertegenwoordigd, waarbij we dan nog kunnen tellen VIII 28, 3 vv., waar we een meerledige vraag van het type - -an -an aantreffen.

B2) Hierbij sluit onmiddellijk aan het type - - anne, dat bij Martialis slechts eenmaal voorkomt, en wel VIII 50, 1: -. Docti Myos anne Myronos?

Dit type is, volgens BRODMUEHLER pag. 61, zeer zeldzaam in de zilveren Latiniteit en komt voornamelijk voor bij de dichters, b.v. Statius, Silius Italicus en Juvenalis.

C. Type numquid-an: slechts tweemaal bij Martialis: VI 68, 7 en VIII 53, 14.

(De partikel numquid komt dus in totaal 25 maal voor en wel alleen in directe vragen ( 23 maal in een-ledige, 2 maal in tweeledige vragen), met (meestal) negatieve betekenis). 
D. Type utrum-an: bij Martialis 5 maal in directe vragen. Blijkens de gegevens van AXELSON p. 90 komt dit type practisch alleen voor bij dichters van de lagere genres of bij iets zorgeloze dichters. Zie ook ThLL s.v. an. Hierbij kan ook 't type utrumne-an (z.o.) vermeld worden.

In het bovenstaande is nog niet verwerkt het epigram III, 20 welk epigram ik hier in zijn geheel wil geven, omdat we hierin o.m. het zo-even vermelde zeer duidelijk terugvinden:

(Lezing volgens HERAEUS) :

III, 20, 1 Dic, Musa, quid agat Canius meus Rufus:

UTRUMNE chartis tradit ille victuris

Legenda temporum acta Claudianorum?

AN quae Neroni falsus astruit scriptor?

5 AN aemulatur inprobi hóyou Phaedri?

Lascivus elegis $A N$ severus herois?

AN in coturnis horridus Sophocleis?

$A N$ otiosus in schola poetarum

lepore tinctos Attico sales narrat?

10 Hinc si recessit, porticum terit templi

AN spatia carpit lentus Argonautarum?

AN delicatae sole rursus Europae

Inter tepentes post meridie buxos

Sedet ambulatve liber acribus curis?

15 TitiNE thermis AN lavatur Agrippae

AN inpudici balneo Tigillini?

AN rure Tulli fruitur atque Lucani?

AN Pollionis dulce currit ad quartum?

AN aestuantis iam profectus ad Baias

20 Piger Lucrino nauculatur in stagno?

„Vis scire, quid agat Canius tuus? Ridet!"

Dit epigram zou men in twee delen kunnen splitsen, n.l. vers $2 \mathrm{t} / \mathrm{m} \mathrm{9}$, in welk deel gevraagd wordt naar de literaire werkzaamheid van Canius Rufus; op welke verzen, naar mijn mening, de aanroeping van de Muze voornamelijk betrekking heeft; en vers $10 \mathrm{t} / \mathrm{m} 19$, waarin gevraagd wordt naar de plaats, waar Canius zich bevindt, en wat hij daar doet. Dit alles wordt dan omlijst door de vraag van Martialis (vers 1) en het antwoord van de Muze (vers 21), welk laatste vers tevens nog een voorbeeld is van een vraag zonder partikel, type vis. Vers 2, 3 en 4 zou men samen als een geheel, als een tweeledige vraag (utrumne-an) kunnen beschouwen, waarbij we moeten opmerken, dat de verbinding van utrum en -ne tot één partikel pas in 
de zilveren Latiniteit schijnt tot stand gekomen te zijn; voordien vinden we ze wel gescheiden, b.v. bij Plautus en Terentius (b.v. Utrum itane sit - an -). Zien we dus deze verzen samen als een tweeledige vraag, dan zou men het vraagteken achter Claudianorum beter kunnen weglaten, zoals ook H. J. IZAAC doet in zijn Martialis-uitgave. De verzen $5 \mathrm{t} / \mathrm{m} 9$ vragen dan naar het eventueel beoefenen van andere genres door Canius.

Met 10 begint een nieuw gedeelte, weer in de vorm van een (eigenlijk toch wel) meerledige vraag, waarvan het eerste lid geen partikel draagt. Binnen dit gedeelte vormen de verzen 15 en 16 weer een apart geheel, waarin gevraagd wordt, of Canius zich misschien bevindt in een badgelegenheid, en zo ja, in welke: type -ne -an - an.

\section{GROEP II A: EEN-LEDIGE INDIRECTE VRAGEN.}

Omvatte groep I B bij Martialis slechts een gering aantal plaatsen, de beide nu volgende groepen, omvattende de afhankelijke vraagzinnen, zijn nog zwakker vertegenwoordigd, hetgeen we overigens ook bij menig ander schrijver kunnen waarnemen, b.v. Vitruvius, die kennelijk de oblique vragen zo veel mogelijk vermijdt. Opmerkelijk is, dat Martialis, die, zoals we zagen, in menig opzicht een typisch vertegenwoordiger is van zijn tijd, en ook elementen aan de omgangstaal onlleent, zich ten aanzien van de modus der afhankelijke vragen nog geheel houdt aan de regels van het klassieke Latijn, zodat we bij hem in dit soort zinnen steeds de coniunctivus vinden en niet de indicativus, die we wel bij verschillende van zijn tijdgenoten aantreffen, b.v. weer Vitruvius. Zover als de sermo plebeius, die in de afhankelijke vragen zelfs de voorkeur geeft aan de indicativus (BRODMUEHLER p. 25), is Martialis dus niet gegaan.

De partikels, welke Martialis gebruikt in de een-ledige indirecte vragen, zijn:

an,

en wel na de verba consulo, dubito (eenmaal: VIII 63, 3), ignoro, inspicio, quaero en video, d.w.z. verba, die BRODMUEHLER ons ook voor andere auteurs (o.a. Seneca phil.) opgeeft. Aldus komt an 9 maal voor.

si.

De partikel si vinden we, als vraagpartikel, reeds in het OudLatijn, maar alleen in indirecte vragen; pas de latere schrijvers hebben si ook in directe vragen: Vulgata, Itala, Peregrinatio Aeth., cet. De vraagpartikel si was in de periode van het Laat- 
Latijn gebruikelijk in de volkstaal en is zo ook overgegaan in de Franse taal. Vitruvius gebruikt deze partikel zeer vaak; ook bij Propertius, die vele elementen aan de omgangstaal ontleend heeft, vinden we het vragende $s i$.

Bij Martialis vond ik twee plaatsen, waar geen uitgesproken vraagzinnen staan, maar die toch in dit verband te noemen zijn, n.l. II 14, 5v en IV 71, 1v. In het eerste geval heeft de voor-zin practisch de betekenis van een verbum temptandi, terwijl de tweede plaats luidt:

Quaero diu totam... per urbem, si qua puella neget.

We weten, dat het Latijn na verba, die een "proberen" of "afwachten" aanduiden, si, verbonden met een coniunctivus, heeft, welke partikel wij dan weergeven met ,of, of misschien".

Ofschoon het Latijn zich in deze conditioneel uitdrukt, kan toch niemand ontkennen, dat wij ons hier bevinden op het grensgebied tussen de conditionele en de interrogatieve partikel (vergel. het Griekse ei.) ). De vraag is nu, hoe het staat met genoemd vers.

Een zeker antwoord kan, mijns inziens, niet gegeven worden, maar wanneer ik zie, dat si in de omgangstaal vaak de plaats van een vraagpartikel inneemt, dat Martialis, evenals andere schrijvers, die si vaak vragend gebruiken, op vele plaatsen overeenkomst vertoont met de omgangstaal en eraan ontleend heeft, dat in het verbum quaerere de betekenissen "zoeken" en „vragen” zeer nauw met elkaar verbonden zijn, dat Livius quaerere in de betekenis "vragen" meerdere malen construeert met een afhankelijke vraag, ingeleid door si (zie voorbeelden bij BRODMUEHLER), dan meen ik wel te kunnen stellen, dat Martialis ook hier aan de omgangstaal heeft toegegeven en si als vraagpartikel gebruikt heeft.

De verhouding tussen de conditionele en interrogatieve zinnen zal overigens later, in de paragraaf over de parataxis, wederom ter sprake komen.

Dat si in deze zin zo weinig voorkomt bij Martialis wordt misschien wel verklaard door de volgende woorden van BRODMUEHLER (pag. 10):

"Quae particula (sc. si), quamquam in libris scriptorum argenteae aetatis recedit et multo rarius quam ,an" ab iis ponitur, tamen in sermone plebeio viguit et postremo ceteras omnes particulas interrogativas depulit, id quod ex linguis Romanensibus quae dicuntur, cognoscimus." 
Evenals Martialis geeft o.a. ook Phaedrus in indirecte vragen de voorkeur aan an boven si.

cur: 12 maal.

„Waarom?"

quare: 14 maal.

quid: nergens!

unde (= waarom) alleen I 96, 10.

De omschrijving: quae causa sit alleen $\mathrm{XI} 59,3$.

$$
\text { „Hoe". }
$$

Ut (afhankelijk van aspicio en cerno) : vier maal.

Quomodo: komt drie maal voor, maar dan niet als één woord; b.v. X 68, 9: scire cupis quo casta modo matrona loquaris?

Aan elkaar geschreven vinden we het wel $X 17,8$, maar hier is het een relativum.

qua ratione: vier maal.

Tenslotte nog de formules:

quid ergo: slechts eenmaal in afh. vraag: $X 74,12$, en qui sim (sis, sit): ook dit is, volgens HOFMANN (Umg. Spr. p. 66), ontleend aan de omgangstaal. Martialis heeft het drie maal, waarnaast het ook voorkomt als directe vraag: quis est. De oorzaak van de afwisseling quis/qui zoekt LöFSTEDT (Synt. II pag. 82) in het streven naar vermijding van de z.g. „sigmatismus"; deze zou aanwezig zijn in quis sim, reden waarom men de voorkeur geeft aan qui sim, zoals ook Martialis doet.

\section{B. DISIUNCTIEVE INDIRECTE VRAGEN.}

Hierover kunnen we zeer kort zijn, daar slechts zeer weinig materiaal ons ter beschikking staat; we vinden dan de volgende typen:

A. — - an: vijf maal o.a. XI 60, 1: Sit Phlogis an Chione Veneri magis apta, requiris?

B. utrum - an: bij Martialis 4 maal in 'n indirecte vraag: utrumne - an vinden we slechts 2 maal, en wel VII $7,9 \mathrm{v}$. en XII $65,4 \mathrm{v}$.

De gegevens, in deze paragraaf verzameld, laten ons duidelijk zien, dat Martialis ten aanzien van de constructie van de diverse vraagzinnen volkomen past in het beeld, door BRODMUEHLER, steunend op andere schrijvers, ontworpen, en dat hij ook in deze weer menigmaal nadert tot, dan wel direct ontleend heeft aan 
de omgangstaal van zijn dagen, hoewel we hieronder dan, in het algemeen gesproken, niet mogen verstaan de sermo plebeius, het „vulgaire" Latijn.

\section{§ 3: DE PARATACTISCHE ZINSCONSTRUCTIE.}

Waar men het er algemeen over eens is, dat de omgangstaal bij de opbouw van haar zinnen de voorkeur geeft aan de paratactische uitdrukkingswijze boven de hypotactische, baart het vanzelfsprekend geen verwondering, dat HOFMANN in zijn "Lateinische Umgangssprache" zo uitvoerig ingaat op het probleem van de parataxe, waarvan o.a. KUEHNER-STEGMANN, Satzlehre II p. 160, zegt: „Aber immerhin ist, wie in den neueren Sprachen, so auch im Lateinischen der parataktische Satzbau in der Ausdrucksweise des täglichen Lebens stets beliebt geblieben". Dit geeft ons overigens niet het recht om zonder meer tot beïnvloeding van de zijde der omgangstaal te concluderen, wanneer we bij een dichter als Martialis een sterke voorkeur voor de paratactische constructie waarnemen, zelfs al weten we, dat de taal van deze dichter in meerdere opzichten duidelijke sporen van een dergelijke beinvloeding vertoont. Dezelfde tendenzen immers, die in de omgangstaal leiden tot een dergelijke uitdrukkingswijze, zijn ook - en met hetzelfde resultaat - werkzaam in de taal van de dichters en in bepaalde stijlrichtingen van het rhetorisch proza, zodat we a priori ook met beinvloeding van deze zijde dienen rekening te houden.

Uiteraard zal het niet altijd gemakkelijk zijn uit te maken, of we te doen hebben met een natuurlijke, onbewuste dan wel met een gekunstelde parataxe, maar voor de taak staande ten aanzien van de bij Martialis zo veelvuldig optredende parataxe een gefundeerde keuze te doen uit de drie bovengenoemde verklaringsmogelijkheden, lijkt het mij. gezien de duidelijke en algemeen erkende afkeer van Martialis tegen de leer en de invloed van de rhetoren, wel verantwoord niet in de eerste plaats in deze richting naar een verklaring te zoeken, maar ons te bepalen tot de omgangstaal en de dichtertaal, hetgeen het probleem overigens niet veel eenvoudiger maakt. Zuiver theoretisch kan m.i. deze zaak niet opgelost worden; men zal hiervoor Martialis zelf ter hand moeten nemen en aan de hand van de tekst, van de concrete voorbeelden zijn conclusies dienen te trekken. De wijze, waarop Martialis de parataxe gebruikt, de sfeer van elk gedicht afzonderlijk, de aanwezigheid van andere omgangstaalelementen, het onderwerp van het epigram zullen 
hier onmisbare gegevens verschaffen. Men leze b.v. II 17, 4 en 5 :

Sed ista tonstrix, Ammiane, non tondet, non tondet, inquam. Quid igitur facit? Radit.

\section{Of II 21:}

Basia das aliis, aliis das, Postume, dextram.

Dicis „Utrum mavis? elige.” Malo manum.

Zie III 4; III 38; etc. etc.: telkens weer treft ons de directheid, veroorzaakt door de parataxe; een directheid, die we slechts terugvinden in de taal van alle dag, in de gewone omgangstaal. Deze gedichten kunnen we dan ook maar op één manier lezen, n.l. in de trant van de Ouden: hardop!

Een voor het geven van een verklaring veelbetekenende factor is bovendien, dat, in het algemeen gesproken, in de gehele literatuur van de Zilveren Latiniteit, tot welke periode immers ook onze dichter behoort, voor de paratactische zinsbouw een belangrijke plaats wordt ingeruimd, of, om met KUEHNERSTEGMANN (z.b.) te spreken: „Aber auch sonst tritt seit den Zeiten der silbernen Latinität der Periodenbau der Parataxe gegenüber oft auffallend zurück."

Afgezien van het feit, dat het voornaamste bewijs voor het populaire karakter van de parataxe, zoals deze door Martialis wordt toegepast, geleverd zal worden door het lezen van de epigrammen zelf, kunnen we toch aan de hand van het door HOFMANN (Umg. Spr.) verzamelde materiaal meerdere concrete punten aanwijzen, welke, indien ze veelvuldig voorkomen bij een bepaalde auteur, het populaire karakter van zijn taal verhogen.

a. Verba dicendi, sentiendi, e.d., vaak paratactisch gebruikt. HOFMANN behandelt dan allereerst die verba, die zeer vaak paratactisch gebruikt worden en zich, althans in de omgangstaal, schijnen te verzetten tegen een hypotactische constructie. In Martialis' gedichten vinden we hiervan vele voorbeelden, getuige onderstaande lijst (de tussen haakjes geplaatste getallen geven aan, hoe vaak elk woord aldus gebruikt wordt):

ORO (3) b.v. VIII 39,5 esse velis, oro, servus conviva Tonantis.

PRECOR (18) „VI 38, 9 di, servate, precor, matri sua vota patrique.

ROGO (25) \# III 52, 3 Rogo, non potes ipse videri....?

MONEO (11) "II 47, 1 subdola famosae, moneo, fuge retia moechae. 
PUTO

(20) „I 5, 2, vis, puto, cum libro, Marce, natare tuo.

CREDO (1) "III 72, 7 sed nihil est horum, credo.

FATEOR (10) ”I 90, 5 esse videbaris, fateor, Lucretia nobis.

CONFITEOR ( 1) „III 31, 1 sunt tibi, confiteor, diffusi iugera campi.

(confiteor aldus door Mart. voor het eerst gebruikt!)

Ook vond ik de vorm AMABO: VIII 76, 1 dic verum mihi Marce, dic amabo.

Voorts gebruikt Martialis de formules dic mihi, crede mihi (mihi crede) meestal paratactisch en slechts bij uitzondering met een ervan afhankelijke zin.

DIC MIHI (19) b.v. I 20, 1 dic mihi, quis furor est ${ }^{30}$ )

CREDE MIHI (12) „II 32, 7 non bene, crede mihi, servo servitur amico.

MIHI CREDE (6) „VI 56, 3 extirpa, mihi crede, pilos de corpore toto.

Aldus komen bij Martialis ook onpersoonlijke uitdrukkingen voor, welke menigmaal vervangen worden door concretere en daarom in de omgangstaal geliefde omschrijvingen met res ${ }^{31}$ ), b.v. VII 71, 6 res mira est, ficos non habet unus ager (= mirum est).

b. Parataxe i.pl.v. coniunctionele, hypotactische constructie.

Vervolgens vermijdt de omgangstaal zeer vaak coniunctionele zinnen, in plaats waarvan dan een paratactische constructie (vaak asyndetisch verbonden) gebruikt wordt; aldus kan onder een grammaticale parataxe een logische hypotaxe schuil gaan. Zo hebben we eigenlijk te doen met een CAUSALE betekenis in sp. 12, 8 sic genitum numen credite, nata fera est. (,ge kunt veilig aannemen, dat die god zo geboren is, daar zelfs een wild dier aldus ter wereld kwam".)

Een TEMPORELE betekenis is aanwezig in II 18, 3 mane salutatum venio, tu diceris isse/ante salutatum.

CONCESSIEF is de ondergrond in

30) Reeds in Martialis' tijd (maar vooral later) wordt de modus van afh.vragen soms verwaarloosd. Aldus zou hier sprake kunnen zijn van een hypotactische constructie, ware het niet, dat Mart., blijkens het hoofdstuk over de vraagzinnen, in afh.vragen steeds de coniunctivus gebruikt.

31) Andere voorb. van deze omschrijving zijn: $\mathrm{XI}: 5,3$ a $\mathrm{rd}$ u a $\mathrm{res}$ haec est; III 63, 14 res pertricosa est; III 12, 3 ressalsa es t. 
sp. 3, 11 en 12 vox diversa sonat populorum, tum tamen una est/cum verus patriae diceris esse pater.

en III 5, 7 quae te... sinu excipiet, tu vel pulverulentus eas.

Zeer vaak vinden we bij Martialis een paratactische constructie in plaats van een CONDITIONELE zin. FRIEDLAENDER (ad II 44, 1) noemt dit „Auslassung von si”, een term, die m.i. niet juist is, daar hij een hypotactische constructie veronderstelt, waarbij slechts de inleidende coniunctie werd weggelaten; in feite is er hier echter van een hypotaxe geen sprake. Het geringe aantal voorbeelden voor dit verschijnsel, door FRIEDLAENDER gegeven, kan gemakkelijk uitgebreid worden, b.v. I $109,21 \mathrm{vv}$. Issam denique pone cum tabella:

aut utramque putabis esse veram, aut utramque putabis esse pictam.

I 58, 6 hoc da tu mihi, pluris emam.

II 29,10 splenia tolle, leges.

Een parataxe in plaats van sive - sive komt, hoewel veel minder frequent, toch voor bij Martialis; zo

I 79, 2 est, non est quod agas, Attale, semper agis.

Waren het in de eerste drie gegeven voorbeelden imperativi, die een si-zin vervangen, ook vraagzinnen vervullen zeer vaak deze functie, b.v.

II 16, 6 vis fieri sanus? stragula sume mea. ${ }^{32}$ )

Het aantal paratactische vraagzinnen, de functie van een hypotactische conditionele zin vervullend, is bij Martialis zo groot, dat dit verschijnsel een uitweiding rechtvaardigt. Men neemt algemeen aan, dat de vraagzinnen, ingeleid door de vraagpartikel si, zich ontwikkeld hebben uit de conditionele zinnen. (Reeds in het Oud-Latijn vinden we enkele afhankelijke vragen met de partikel si; pas later worden ook onafhankelijke vragen door deze partikel ingeleid.)

In alle bescheidenheid zou ik echter de vraag willen opperen, of deze zienswijze wel geheel juist is. Zou het niet beter zijn, juist van de vraagzinnen uit te gaan, die dan, paratactisch gebruikt, maar een conditionele functie vervullend, op den duur geleid hebben tot het ontstaan van de hypotactische constructie? Deze vraagzinnen konden dan ingeleid worden door si, dat oorspronkelijk een adverbium met de betekenis ,zó" was, maar zich kan ontwikkeld hebben tot een vraagpartikel.

Dit alles brengt als consequentie met zich mee, dat si, als vraagpartikel, oorspronkelijk onafhankelijke vragen zou ingeleid

32) Zie voor dit $v$ is -type ook de paragraaf over de Vraagzinnen. 
hebben en pas hierna afhankelijke. In de bronnen van het OudLatijn vinden we hiervoor wel geen steun, maar dit is m.i. geen overwegend bezwaar, daar ten aanzien van de overlevering het toeval een rol kan spelen en de geschetste ontwikkeling vóór de ons door de bronnen bekende periode heeft plaats gehad. Deze ontwikkelingsgang lijkt mij psychologisch en logisch waarschijnlijker dan de omgekeerde, waarbij men de conditionele zinnen primair, en de (afhankelijke) vragen met si secundair stelt. Ook HOFMANN (Gramm. p. 771) gaat uit van de formule: si iubes? abeo (zó beveel je het? dan ga ik!) > si iubes, abeo (zo je het beveelt, ga ik). Als logische consequentie zou hieruit volgen, dat dus de zinnen met si regelmatig vooraf hebben moeten gaan aan de hoofdzin. Zou dit inderdaad juist zijn voor de oudste taaltoestand en zou men ook hier nog de stelregel mogen toepassen, dat een bepaald verschijnsel uit het Oud-Latijn vaak, door middel van de omgangstaal, bewaard bleef en zo later weer opdook in het Laat-Latijn, dan zou het zijn waarde hebben een onderzoek in te stellen naar de plaatsing van de si-zinnen bij de „populaire”, en, ter contrôle, ook bij andere auteurs.

Hoewel deze kwestie, aldus gesteld, buiten het raam van mijn onderwerp valt, wil ik hier toch de resultaten van mijn desbetreffend onderzoek ten aanzien van Martialis mededelen. ${ }^{33}$ ) Onderstaand schema laat behalve de frequentie zien, hoe de coniunctionele conditionele zinnen over de metra verdeeld zijn:

\begin{tabular}{lllccc}
\hline & dact. & chol. & hend. & epist. & totaal \\
\hline si-zin vóór hoofdzin & 221 & 15 & 53 & 4 & 293 \\
si-zin ná hoofdzin & 106 & 1 & 12 & 3 & 122 \\
\hline totaal & 327 & 16 & 65 & 7 & 415
\end{tabular}

Deze gegevens leren ons allereerst, dat èn absoluut èn relatief genomen de meeste si-zinnen (dus een belangrijke groep van de hypotactische constructies) voorkomen in dactyli en dat ze het minst frequent zijn in die metra, waar we de hypotaxe a priori ook het minst zouden verwachten. Intussen wekt dit toch enige bevreemding, daar ik in het voorafgaande herhaaldelijk moest concluderen, dat van een dergelijke te verwachten verdeling van populaire en minder populaire verschijnselen over

33) De irrealis, een voor dit onderzoek te speciaal doorgevoerde constructie, laat ik hierbij verder buiten beschouwing. Van de 26 bij Mart. voorkomende irrealis-constructies zijn er 19 gevallen, waarbij de si-zin vó́r, en 7 , waarbij hị achter de hoofdzin staat. 
de verschillende metra, geen sprake was. Zou het wellicht zo zijn, dat Martialis ten aanzien van vormleer en vocabularium geen onderscheid maakt tussen de diverse metra (als gevolg van metrische dwang, èn omdat Martialis' keuze van de metra niet bepaald wordt door de beschreven onderwerpen), maar dat hij, zij het dan meestal onbewust, een dergelijk onderscheid wel makt ten aanzien van verschijnselen van syntactische aard?

Boven vermeldde $i k$ bij wijze van (niet bewezen en vooralsnog niet te bewijzen) hypothese, dat, áls de ontwikkeling van de conditionele zinnen zo verlopen is, als ik beschreef, de sporen hiervan het best bewaard kúnnen zijn bij de meest populaire auteurs. Zou dit juist blijken te zijn, dan is de toestand bij Martialis veelzeggend; want waar in dactyli slechts twee maal zoveel si-zinnen vóór de hoofdzin staan als erna, vinden we in choliamben slechts één si-zin, in hendecasyllabi $\pm 20 \%$ na de hoofdzin.

Intussen geef ik dit alles dus slechts als hypothese; men zou hiervoor een onderzoek moeten instellen naar de toestand bij een grote groep Latijnse auteurs, terwijl men, daar de geschetste ontwikkeling heeft plaats gehad vóór het moment, waarop bruikbare bronnen voor ons aanwezig zijn, waarschijnlijk ook andere indo-europese talen ter vergelijking zou moeten aanhalen; ik denk b.v. aan het Grieks, waar we iets eenders vinden in het gebruik van de partikel $\varepsilon^{i}$, en aan het Engels (if).

Keren we nu terug naar ons uitgangspunt. Ik gaf als voorbeeld voor een paratactische constructie met conditionele waarde een vraagzin van het type-vis. Hiervan biedt Martialis ons meerdere voorbeelden, o.a. II 10, 3; II 72, 7; IV 74, 4; VI 50, 5; XII 22,2 ; XII 36, 11. Hiernaast staan meerdere gevallen van een hypotactische conditionele zin, waarin ook dezelfde verbaalvorm vis voorkomt:

IV 86, 1 si vis auribus Atticis probari.

$\mathrm{V}$ 52, 6 si vis, ut loquar, tace.

Zo o.a. ook nog VIII 73, 3; IX 25, 9; XIV 69, 1; XIV 198, 1.

c. Parenthese.

Tenslotte wil ik nog even de aandacht vestigen op de parenthese, waarover HOFMANN (Umg. Spr. p. 114) zegt: „Noch von einer anderen Seite her erhält die umgangssprachliche Neigung zur Parataxe Zuzug und Stütze. Ein uraltes, in der Umgangssprache erhalten gebliebenes Mittel der Satzbildung ist die Parenthese, die durch Einschaltungen meist subjektiver Art den natürlichen Fortgang des Gedankens und seines sprach- 
lichen Ausdrucks hemmt". Ook bij Martialis vinden we hiervan talrijke voorbeelden; om slechts enkele te noemen:

I 37,1 ventris onus misero - nec te pudet - excipis auro. I $117,13 \mathrm{v} \ldots . . . \mathrm{Nec}$ rogas Atrectum

- hoc nomen dominus gerit tabernae -

de primo dabit alterove nido.

II 62, 3 hoc praestas, Labiene, tuae - quis nescit? - amicae.

De gegevens van deze paragraaf samenvattend, kunnen we dus zeggen, dat de parataxe, hoewel op zich niet het uitsluitend voorrecht van de omgangstaal, door Martialis toch wel op dusdanige wijze is gebruikt, dat de kleur, welke zij aan zijn taal, aan zijn dictie geeft, onmiddellijk het beeld en de sfeer van de omgangstaal oproept èn bewerkt. Ook de concrete gevallen, die ik vermeldde, - en die door HOFMANN als kenmerkend voor de omgangstaal werden geschetst -, zijn van een dusdanige frequentie (alleen de eerste groep omvat reeds meer dan 130 verschillende plaatsen!), dat zij deze indruk in belangrijke mate versterken.

\section{$\S$ 4. DE NEUTRA.}

Over het gebruik van de pluralis-vorm der neutra deelt BAEHRENS p. 47 ons mede: „Dieser - Plural gaudia mit kollektiver Bedeutung begegnet uns aber besonders häufig in der Umgangssprache". De verdere ontwikkeling van deze vormen tot vrouwelijke, enkelvoudige substantiva verloopt in de omgangstaal geheel langs natuurlijke weg. Het voorkomen van deze pluralis in de poëtische taal moet wel verklaard worden als een ontlening aan, of minstens een beïnvloeding van de zijde van de omgangstaal, waarbij het metrum blijkbaar de beslissende factor is geweest. Het neutrum plurale vinden we immers regelmatig in de dactyli, terwijl het neutrum singulare hier slechts zelden wordt aangetroffen en als het ware gereserveerd schijnt te zijn voor andere versmaten.

In dit algemene beeld past Martialis volkomen; reeds SCHNEIDER p. 4 wijst erop, dat onze dichter vaak de pluralis in plaats van de singularis bezigt omwille van het metrum, wanneer de singularis, of een bijbehorend woord (adiectivum of verbum) niet bruikbaar is. Als voorbeeld haalt hij aan gaudia, dat 18 maal in disticha voorkomt, waarnaast gaudium in I 109, 7 in hendecasyllabus, en III 64, 2; V 37, 17 in choliambi staat. Ook noemt hij in dit verband otium, praemium en prandium. Hier- 
naast staan natuurlijk ook gevallen, waar bovenstaande regel iets minder consequent is doorgevoerd (b.v. fatum, vinum), maar in het algemeen wijkt Martialis toch niet af van de in deze bestaande gewoonte. Door LöFSTEDT, Synt. I, p. $42 \mathrm{vv}$, waar ook Martialis genoemd wordt, is dit alles nog eens onderstreept.

Een tweede byzonderheid, die hier onze aandacht vraagt, is het gebruik van de casus obliqui van deze neutra. Als algemene norm kunnen we immers stellen, dat voor de casus obliqui de singularis-vorm de voorkeur geniet; als zeer duidelijk voorbeeld noemt LöFSTEDT (z.b.) vinum, waarvan we bij Martialis de vormen vina 27 , vinum 6,vini 1 , vino 5 maal aantreffen; andere vormen lezen we niet bij onze dichter! Hierdoor wordt de byzondere kracht van het neutrum plurale op -a dus wel zeer duidelijk bewezen, ook al vinden we soms een afwijking van de algemeen aanvaarde norm. Ten aanzien van Martialis stelde $i k$ in dit verband een onderzoek in, omvattende alle neutra van de tweede declinatie, met dien verstande, dat ik mij hierbij baseerde op de niet altijd even betrouwbare index van FRIEDLAENDER, zodat bij de onderstaande getallen enige reserve in acht genomen moet worden, al wordt hierdoor aan het totaalbeeld dan ook weinig veranderd. De frequentie van de verschillende naamvallen is dan als volgt ${ }^{34}$ ):

\begin{tabular}{cccccc}
\multicolumn{3}{c}{ SINGULARIS } & \multicolumn{3}{c}{ PLURALIS } \\
nom./acc. & gen. & dat. & nom./acc. & gen. & dat. \\
276 & 78 & 244 & 715 & 12 & 104
\end{tabular}

Deze getallen bewijzen, dat Martialis bij de nominatiefaccusatief-vormen de voorkeur geeft aan de pluralis (72\%) boven de singularis (28\%). (Opvallend is, dat deze percentages in overeenstemming zijn met het aantal dactylische en nietdactylische verzen: resp. \pm 70 en $39 \%$ !). Van de genitief-vormen is de pluralis op -orum blijkbaar zeer weinig geliefd (slechts $13 \%$ van het totaal-aantal genitivi), terwijl Martialis een duidelijke voorliefde heeft voor de genitivus singularis $(87 \%)$. De dativus pluralis is iets beter vertegenwoordigd (30\%), maar toch nog sterk in de minderheid tegenover de dativus singularis $(70 \%)$.

34) Hierbij zijn de neutra, voorkomend in de begeleidende epistulae en in de titels van bk. XIII en XIV meegeteld; de woorden a $\mathbf{r} \mathrm{m}$, arva, carbasa, castra, serta, sestertia, die vrijwel steeds in de pluralis gebruikt worden, heb ik buiten beschouwing gelaten, omdat Mart. hler niet vrij was zijn eigen keuze te bepalen. 
Met bovenstaande gegevens voor ogen meen ik te mogen concluderen, dat Martialis de in de Romeinse dichtertaal bestaande usance, die met de tendentie van de omgangstaal samenvalt, met graagte benut heeft, te meer, waar hij ook in vele andere opzichten bij zijn lezers reminiscenties aan hun omgangstaal oproept: hebben andere Romeinse dichters hier, ter oplossing van een grote moeilijkheid, gegrepen naar een door de omgangstaal gegeven voorbeeld, dan zal zeker Martialis hiertegen geen enkel bezwaar gehad hebben. Martialis' lezers zullen bij het lezen van de neutrum-plurale-vormen hierin, zij het dan onbewust, primair een van de vele contactpunten met hun omgangstaal gevoeld hebben.

\section{\$. HET GEBRUIK VAN DE ACCUSATIVUS.}

Blijkens NELSON p. 145 is de accusativus reeds in de dagen van Petronius zich aan het ontwikkelen tot de casus generalis; in Petronius' Satiricon vinden we hiervoor reeds enige duidelijke aanwijzingen, en dan niet slechts in de meer vulgaire gedeelten. NELSON meent dan ook, dat dit verschijnsel niet alleen in de volkstaal, maar ook in de meer beschaafde omgangstaal voorkwam. Zo regeert bij Petronius o.a. het verbum maledicere, in de klassieke periode met de dativus geconstrueerd, op verscheidene plaatsen de accusativus. In dit verband is dan ook de Martialis-plaats III 80,1 opvallend, waar de verschillende tekstuitgaven steeds nulli maledicis geven, hoewel de codices van familie A nullum maledicis hebben. Mijns inziens zou er geen bezwaar tegen bestaan deze laatste lezing in de tekst te plaatsen, daar 1) het metrum dit toelaat, 2) de codices $A$ in twijfelgevallen de voorkeur verdienen (HERAEUS, Inleiding z. Neueren Martialkritik), 3) Martialis zeer veel omgangstaalelementen in zijn oeuvre toelaat (in hetzelfde vers nog: de nullo loqueris, z.o.), 4) deze accusativus, getuige Petronius, in Martialis' dagen zeker niet meer ongewoon was. De enige plaats, waar we maledicere nog aantreffen bij Martialis, IX 10, 2, geeft in deze geen verduidelijking. Het bovenstaande moest om genoemde redenen hier vermeld worden, hoewel ik, daar naar mijn gevoelen het dwingende bewijs ontbreekt, het in mijn conclusies liever buiten beschouwing wil laten.

Wanneer bij het mediale indui het kledingstuk, waarmede men zich bekleedt, door de accusativus wordt aangeduid, hebben we, blijkens RIEMANN p. 223 te doen met een construc- 
tie, die eigen is aan de omgangstaal. Bij Plaut. Men. 514 vinden we hiervan reeds een voorbeeld; voor Martialis zijn in dit verband van belang VIII 48, 2 induiturque togam, en V 23, 1 herbarum fueras indutus, Basse, colores (in dit vers bovendien een „foutieve” vorming van het plusq. perf. Zie p. 88 vv.)

Bij Petron. 44, 18 lezen we lovem aquam exorabant; NELSON p. 144 tekent hierbij aan, dat een dergelijke dubbele accusativus wel gewoon is bij rogare en poscere, maar dat de uitbreiding van deze constructie tot een werkwoord als exorare tot de omgangstaal moet gerekend worden. Bij Martialis vond ik hiervoor slechts één voorbeeld, en wel XI 60, 9 exorare, dei, si vos tam magna liceret.

\section{§ 6: HET GEBRUIK VAN PRAEPOSITIES.}

Naar aanleiding van Phaedrus I 16, 6 fugere de conspectu, waar het klassieke Latijn fugere conspectum of, zo men een praepositie bezigt, fugere e conspectu zou geschreven hebben, wijst BERTSCHINGER p. 12 erop, dat de de meest geliefde praepositie van het Laat-Latijn geworden is. In de omgangstaal was de tendenz hiertoe reeds zeer vroeg aanwezig, hetgeen men kan opmaken uit het feit, dat we b.v. bij Plautus al enkele malen een verwisseling van de, in betekenis toch eigenlijk onderscheiden, praeposities $a(b)$, de en $e(x)$ kunnen waarnemen, zo Men. 599 abire de foro. Vooral in de gesproken taal heeft de de neiging $a b$ en ex te vervangen. DEL s.v. $a(b)$. Bij de zojuist genoemde Phaedrusplaats merkt BERTSCHINGER op, dat daar de praepositie $e$ niet had kunnen staan om metrische redenen; dit kan men echter niet zeggen van Martialis IX 88, 4 aper fugit de cavea. Hier hebben we dus al direct een duidelijk voorbeeld van de uitbreiding van de praepositie de, ook in het oeuvre van Martialis.

In dit verband kan eveneens vermeld worden XIV 12, 1, waar we het verbum implere, dat gewoonlijk met een ablativus instrumentalis geconstrueerd wordt, verbonden vinden met de (men denke aan fr. remplir de).

Typerend is voorts de populaire uitdrukking dicere de aliquo (voor dicere in aliquem), waar dicere de betekenis draagt van male dicere; een dergelijke brachylogie lezen we vaker op inscripties en zij kan tot de omgangstaal gerekend worden. Martialis heeft VII 18, 1 de qua nec femina possit/dicere; hiermee op een lijn te stellen is III 80 , I de nullo loqueris, nulli 
maledicis, waar het verbum loqui wel om wille van de variatio geschreven zal zijn. Vgl. LöFSTEDT Komm. Peregr. p. 283.

De juiste frequentie van de praeposities de en ex bij Martialis is mij niet bekend. Ik stelde echter een desbetreffend onderzoek in naar de toestand in de boeken I, III, VII en XII. Hier bleek $e(x)$ in totaal 8 , de 38 maal vertegenwoordigd te zijn, waaruit een duidelijke voorkeur voor de blijkt. De praepositie $a(b)$ komt in deze boeken 49 maal voor, maar hierbij zijn ook die gevallen meegerekend, waar $a(b)$ een andere functie vervult als in het onderhavige geval bedoeld is. Ter vergelijking moge hier aangehaald worden, dat Vergilius in de eerste twee boeken van zijn Aeneis $e(x) 16$, de 11 maal gebruikt.

Voorts dient hier nog vermeld te worden de mededeling van AXELSON p. 119 v., dat de schrijfwijze $e x$ in iedere periode van het Latijn in de volkstaal het meest geliefd was in tegenstelling tot de schrijfwijze $e$; ook Martialis geeft duidelijk de voorkeur aan $e x$, ook vóór consonanten ( $e$ lezen we slechts 3 maal). ${ }^{35}$ )

De praepositie ad treffen we aan in de uitdrukking (non) facit ad (stomachum e.a.), welke uitdrukking blijkbaar behoorde tot de omgangstaal en die we, naast Cic. ad fam. VII 1, 2, Plin. ep. I 24, 3 en Petron. c. 48, ook lezen bij Martialis X 45, 6 non facit ad stomachum nostra lagona tuum; XIII 3, 8 non facit ad stomachum; I 51, 1 non facit ad saevos cervix, nisi prima, leones.

\section{§ 7: DE PRONOMINA EN DISTRIBUTIVA.}

De pronomina personalia, als subject in de klassieke periode vrijwel alleen dan geduld, wanneer er sprake is van een sterke nadruk en/of tegenstelling, worden in de postklassieke tijd steeds vaker gebruikt, ook wanneer aan vermelde voorwaarde niet is voldaan. NELSON p. 120 vv. b.v. wijst erop, dat we bij Petronius reeds zeer veel gevallen van een dergelijk zuiver mechanisch gebruik vinden, waarbij hij tot de conclusie komt, dat we, gezien het voorkomen van deze mechanisatie zowel in Petronius' vulgaire als in zijn urbane dictie, in dit „overbodige" gebruik van de pronomina personalia niet een verschijnsel, dat speciaal eigen is aan de volkstaal van Petronius' dagen, dienen te zien. Volgens PETERS p. 109 vertoont ook Phaedrus "sporen van dit vrijere gebruik van de pronomina personalia". We zullen in het vol-

35) NELSON p. 117 telt bij Petron. 70 plaatsen voor e $x$ (ook vóbr consonanten), slechts 6 voor $\bullet$. Zie ook LöFSTEDT, Komm. Peregr. p. $89 \mathrm{vv}$ en SCHMALZ-HOFMANN p. 528. 
gende zien, dat Martialis meer dan enkel "sporen" vertoont. Daar FRIEDLAENDER in zijn Index deze pronomina niet, of absoluut onvolledig opneemt, heb ik zelf de epigrammen van Martialis hierop onderzocht, waarbij ik mij beperkt heb tot de pronomina van de eerste en tweede persoon. In onderstaand schema vindt men dan aangegeven, hoe vaak Martialis de verschillende pronomina - met nadruk (m.n.) of zonder nadruk (z.n.) - heeft, waarbij tevens is vermeld, hoe de verdeling ervan is over de diverse metra (cet. = cetera metra; ep. = epistolae) .

\begin{tabular}{|c|c|c|c|c|c|c|c|c|}
\hline & \multicolumn{2}{|c|}{ EGO } & \multicolumn{2}{|c|}{$\overline{\mathrm{T} U}$} & \multicolumn{2}{|c|}{ NOS } & \multicolumn{2}{|c|}{ VOS } \\
\hline & m.n. & z.n. & m.n. & z.n. & m.n. & z.n. & m.n. & z.n. \\
\hline dactyli & 30 & 18 & 131 & 48 & 14 & 1 & 5 & - \\
\hline chol. & 2 & 2 & 5 & 4 & - & - & - & 1 \\
\hline hendec. & 4 & 2 & 28 & 15 & 2 & 1 & 2 & 1 \\
\hline cet. & - & - & 1 & - & - & - & - & - \\
\hline ep. & 2 & - & 2 & - & - & - & - & - \\
\hline totaal & 38 & 22 & 167 & 67 & 16 & 2 & 7 & 2 \\
\hline
\end{tabular}

Alles te samen worden deze pronomina 228 maal met nadruk, dus in normale functie gebruikt, maar hiertegenover staan $\mathbf{9 3}$ gevallen, waarin het pronomen eigenlijk overbodig, want zuiver mechanisch is; een aantal gevallen dus, waaraan men zeker niet achteloos mag voorbijgaan. (Hiernaast vinden we echter zeer vele plaatsen, waar het pronomen personale, overbodig als het is, inderdaad wordt weggelaten, hetgeen echter niet bevreemdend is, daar we hier nog zeer ver verwijderd zijn van de toestand, zoals die zich in het laat-Latijn en vandaar in de Romaanse talen ontwikkeld heeft.) De invloed van de omgangstaal is dus bij Martialis sterk merkbaar! Vinden we bij Petronius met name het mechanisch geworden ego, bij Martialis is het vooral $t u$, dat op de voorgrond treedt. Nos en vos echter zijn bij beide minder vaak vertegenwoordigd.

Meerdere malen lezen we het mechanische $t u$ bij een imperativus; zuiver grammaticaal gezien is het pronomen hier overbodig, maar daar de toevoeging ervan aan de imperativus een „pathetische nuance" geeft, is dit gebruik zeer geschikt voor de poëzie èn voor de omgangstaal (NELSON p. 121). Vaak ook zien we bij Martialis het mechanische pronomen dan gebruikt, wanneer in de nabijheid een demonstrativum staat.

Het is natuurlijk onmogelijk (en tevens onnodig) hier alle plaatsen te vermelden, welke een overbodig pron. personale bevatten. Enige voorbeelden mogen derhalve volstaan: 
VII 88, 5 Hoc ego maluerim, quam si -

VII 97, 1 Nosti si bene Caesium, libelle, -

vs. 4 - illi tu dabis haec vel occupato.

VIII 59, 5 Hunc tu convivam cautus servare memento. (In dit laatste vers dus demonstr. èn imperat.)

Tenslotte nog een enkele opmerking betreffende de verdeling van dit verschijnsel over de diverse versmaten: bij zeer nauwkeurige berekening blijkt het mechanische gebruik naar verhouding iets meer vertegenwoordigd te zijn in dactyli dan in cet.

Practisch echter kan men zeggen, dat Martialis hier geen onderscheid maakt tussen de verschillende metra.

Volgens RIEMANN p. 42 hebben we met een minder correcte spreekwijze te doen, wanneer het pronomen uterque, dat op zich reeds een meervoudige betekenis heeft, in de pluralisvorm gebruikt wordt. Dit komt vooral voor in de ,langue familière". NELSON p. 159 vermeldt bovendien de auteurs, waar dit gebruik voorkomt: Ter., Catull., hier en daar bij Cic. (b.v. ad fam. 8, 11, 1; verder vooral bij zijn correspondenten), Varro rust., Bell. Hisp., Afr., Nep., Sall., Hor. sat., Prop., vaker bij Liv. en post., ook inscr.; Petron. heeft het èn in vulgaire èn in urbane dictie. De pluralis utrique is dus niet uitsluitend eigen aan de volkstaal, maar is, zoals NELSON het uitdrukt, „hoogstens een beetje "vlotte" omgangstaal geweest". Bij Martialis nu, die overigens steeds de singularis heeft, lezen we toch op één plaats de pluralis-vorm, en wel I 6, 5 utrisque. Deze lezing, die door de verschillende edities wordt overgenomen, steunt op de codices $B$; de codices $C$ hebben dit blijkbaar "verbeterd" in utrique, een correctie, die blijkens het bovenstaande niet noodzakelijk is.

Hiermede practisch op een lijn te stellen is het gebruik van de singularis van de distributieve telwoorden, die overigens gewoonlijk in de pluralis verschijnen; volgens RIEMANN p. 22 is dit uitzonderlijke gebruik ofwel "vulgair" ofwel poëtisch. Bij een Vergilius zal dit inderdaad een poëtisme zijn; om bij andere auteurs echter van een vulgarisme te spreken, lijkt mij wel iets te sterk, daar we een dergelijke singularis ook wel vinden

36) figere is hier gelijk an c rucifige re. FRIEDL. merkt a.l. op: $f$ i $g$ is fur c r u c $f^{\prime}$ i $g$ is mag der Umgangssprache angehört haben. Es findet sich sonst absolut gebraucht - erst bei christ. Schriftstellern'. Hieraan voegt hij dan enkele voorb. uit Tert. en Lact. toe. 
bij Plinius de Oudere. Martialis, die in tientallen gevallen deze distributiva in de normale pluralis-vorm gebruikt, heeft echter ook wel eens de singularis, zo XII 76, 1 quaterno aere ${ }^{37}$ ); XIV 17,1 bis seno puncto; IV 64, 32 centeno ligone; VIII 45, 4 centeno consule.

\section{§ 8: DE VERVANGING VAN DE SUPERLATIVUS.}

De samenstelling van adiectiva (of adverbia) met per ter vervanging van de superlativus is speciaal eigen aan de omgangstaal. De beste prozaschrijvers, zoals Caesar en Tacitus, zijn in dit opzicht zeer terughoudend. AXELSON p. 37v toont aan, dat deze superlatief-vorming eveneens zeer onpoëtisch is; bij Lucretius vinden we een groot aantal van deze vormingen, maar AXELSON, die bovendien op vele andere gegevens steunt, merkt hierbij op, dat het gebruik van deze composita eens te meer getuigt van de "Unfeinheit der lukrezischen Diktion”. In de Augusteïsche poëzie vinden we, buiten Hor. sat., zeer weinig voorbeelden van dit verschijnsel. Dergelijke composita zijn dus, behalve populair, ook zeer onpoëtisch en zelfs in de lagere genres zeer weinig geliefd. Ook Martialis is in dit opzicht voorzichtig; van de 4 voorbeelden, die we bij hem aantreffen, zijn er 3 innovaties en dus expressief; I 76, 10 heeft hij perinane sophos: perinanis komt vóór Martialis nergens voor; de verbinding met de populaire exclamatie sophos is typerend. Pertricosus komt buiten Martialis (III 63, 14 pertricosa res) niet meer voor; het populaire karakter van dit woord blijkt, behalve uit de samenstelling met per, eveneens uit het in de omgangstaal vaak gebruikte suff. -osus, en uit het feit, dat dit woord is afgeleid van het populaire tricae; voor de verbinding met res, zie p. 102 . VII 75, 2 lezen we perridicula res: perridiculus staat bij Martialis voor het eerst in poezie. Niet nieuw is perlucidus (IX 2, 9; XII 38,3). Deze plaatsen zijn alle dactyli; het metrum behoeft echter niet seeds de dwingende oorzaak geweest te zijn; tricosissima zou ook passen in de dactylische versmaat. Behalve per wordt ook prae wel aldus gebruikt; vgl. Mart. IV 18, 4 praegravis unda.

\section{§ 9: DE INVERSIE VAN DE COPULA ET.}

LöFSTEDT bespreekt Komm. Peregr. p. 313v de inversie van de copulatieve partikels, en deelt ons mede, dat dit verschijnsel

37) Hierbij merkt FRIEDL. op: „Beträge unter einem Denar wurden in volksthlimlicher Weise nicht selten durch das blosze Zahlwort mit dem Zusatz a eris (hier abl,) ausgedrückt". Het uitzonderltjke gebruik van het distributivum is hem hierbij echter ontgaan! 
sedert de Augusteische periode voorkomt bij de vertegenwoordigers van de meer verheven poëtische genres, en voorts bij die auteurs, die geregeld ontlenen aan de omgangstaal; dit laatste geldt echter zeer byzonder voor lateren als Peregr. Aeth., Mulom. Chir., Apic. Ook Martialis echter maakt zeer vaak gebruik van de inversie van de partikel et; naar mijn mening kunnen we t.a.v. Martialis de grond van het toepassen dezer inversie wel eerder zoeken in de omgangstaal dan in de poëtische stijl (al imiteert hij dan ook menigmaal de Augusteïsche dichters!)

FRIEDLAENDER tekent bij I 26, 8 egerit et aan, dat de inversie van de copula et bij Martialis \pm 60 maal voorkomt. Als zeer duidelijk voorbeeld noem ik IX 59, 12 culpavit statuas et, Polyclite, tuas (voor: et culp.st.t.). (Overigens is dit de enige plaats, waar et voorafgegaan wordt door meer dan één woord). De andere plaatsen vindt men bij FRIEDLAENDER 1.c. vermeld.

\section{§ 10: VERSTERKING VAN DE IMPERATIVUS DOOR I.}

RUCKDESCHEL wijst er p. 129 op, dat de versterking van de imperativus door $i$ wel aan de volkstaal ontleend moet zijn. We vinden hiervan blijkbaar talrijke voorbeelden in de comedie, niet echter in het voor-Liviaanse proza, vervolgens weer wel bij Petron.; ook in Hor. sat. en ep. ontbreekt deze versterking niet. Martialis blijft evenmin achter en gebruikt naast $i$ ook menigmaal $i$ nunc, waarbij nunc zijn deictisch-temporele waarde geheel verloren heeft: zo X 96, $13 i$, cole nunc reges; I 42, 6 i nunc et... nega; sp. 23, 6; II 6, 1; VIII 6, 3; IX 2, 13.

\section{§ 11: ENKELE INFINITIVUS-CONSTRUCTIES.}

RIEMANN wijst er p. 331 op, dat de verbinding van de imperativi cave en parce met een infinitivus (e.g. cave facere), naar analogie van noli facere, behoort tot de familiaire uitdrukkingswijze $\left.{ }^{39}\right)$; en op p. 359 zegt hij, dat de constructie van cave + coniunctivus (zonder ne) eveneens een familiair karakter draagt. Voor cave + inf. vond ik bij Martialis geen enkel voorbeeld; parce daarentegen wordt door Martialis nooit met een coniunctivus, maar slechts met een inf. geconstrueerd, en

\footnotetext{
38) Hiermee kan vergeleken worden de verbinding van optare met een infinitivus welke constr. zeker tot de omgangstaal behoort. Vgl. RUCKDESCHEL p. 119. Voor Mart., zie IX 51, 4. Hetzelfde geldt t.a.v. $n$ ovis se + inf.: Mart. II 52, 1; III 58, 43; VII 25, 8; X 15, 2; $X 33,9$; etc. (RUCKDESCHEL p. 123).
} 
wel in III 68, 4 nudos parce videre viros; XI 22, 4 parce fututrici sollicitare manu; XI 43, 11 parce dare; XIV 105, 2 parce ludere; XIV 118, 2 parce miscere. De constructie cave(to) ne + coni. komt wel enkele malen voor bij Martialis, maar hiernaast lezen we toch ook VI 78, 3 bibas caveto; VI 79, 1 sciat hoc Fortuna caveto; X 72, 12 caveto - - - loquaris. De minder correcte constructies zijn dus door Martialis zeker niet vermeden. ${ }^{39}$ )

Geheel in dezelfde lijn ligt ook het verbinden van de imperativus fac met een coni., zonder toevoeging van de coni. $u$ t; uitdrukkingen als fac sciam, fac me ames dienen practisch ter vervanging van een imperativus en getuigen, blijkens RIEMANN p. 360 , van een familiaire inslag. Bij Martialis vond ik deze voorbeelden: V 56, 9 fac discat; VI 56, 6 fac putent.

Bij meerdere auteurs ${ }^{40}$ ) vinden we gegevens over de vervanging van de accusativus-cum-infinitivo door een meer analyserende quia- of quod-zin. In het licht van deze gegevens zou ik willen beschouwen Martialis' epigram XI 64:

Nescio tam multis quid scribas, Fauste, puellis:

Hoc scio, quod scribit nulla puella tibi.

Het staat voor mij vast, dat we dit quod in vers 2 niet als relativum dienen te beschouwen, maar dat we hier te doen hebben met de coniunctie quod, geschreven in plaats van een inf.-constructie. In Martialis' dagen was dit, ook bij het verbum scire, zeker niet iets ongewoons. Men denke b.v. aan Petron., die, toch niet zó lang vóór Martialis, schreef: 71, 9 scis quod epulum dedi. Bovendien vindt deze opvatting steun bij KUEHNER-STEGMAN (zie voetnoot 40), die, deze kwestie besprekend, o.a .de genoemde Martialis-plaats als voorbeeld aanhaalt. Ik zou echter uit Martialis geen andere plaats kunnen noemen in dit verband; ik heb zelfs de indruk, dat er ook geen andere bestaan, hetgeen intussen niet behoeft te bevreemden, daar, blijkens NELSON p. 182, deze verdringing van de acc.c.inf. in de eerste eeuw na Chr. nog lang niet algemeen is. En wanneer we bij Petronius, die toch bepaalde gedeelten van

39) Vgl. voor dit alles ook RUCKDESCHELl p. 121 en 122, die het populaire karakter bewijst uit het voorkomen bij een bepaalde groep van auteurs.

40) LöFSTEDT, Synt. II p. 265v; id. Komm. Peregr. p. 116vv; G. MAYEN, De particulis quod quia quoniam, quomodo, ut, pro acc. cum infinitivo post verba sentiendi et declarandi positis, Diss. Kiel 1889; P. C. DE BROUWER, De Grieksche en Latijnsche Syntaxis, historisch, linguistisch, psychologisch belicht. Luik 1835, p. 142; P. PERROOHAT, L'infinitif subordonné en latin, Parjjs 1932, p. 132; NELSON p. 18, p. 182v; KUEHINER-STEGMANN, Satzlehre II p. 274. 
zijn oeuvre bewust vulgair of populair gekleurd heeft, al mogen aannemen, dat hij om de ware toestand in de omgangstaal van zijn dagen weer te geven, zeker niet meer dan de vier bij hem voorkomende gevallen behoefde te schrijven, dan geldt dit toch zeker voor Martialis, bij wie we een dergelijke strenge scheidslijn tussen al dan niet populaire gedeelten niet aantreffen. Ook voor Martialis is de acc.c.inf.-constructie nog de normale.

Scio, quod behoeft niet per se tot de volkstaal te behoren, (NELSON p. 18). Een dergelijke coniunctionele zin heeft een meer individuele, dus meer expressieve waarde dan de onpersoonlijke infinitivus. Ook bij Martialis vinden we dus reeds een voorbode van het in laat-Latijn gewoon geworden gebruik. Van belang is, dat onze dichter niet het echt vulgaire scio, quia geschreven heeft. Tenslotte zij nog vermeld, dat ook de Martialisplaats de opvatting van LöFSTEDT bevestigt, dat in een dergelijk geval na het verbum scire de indicativus normaal is.

Hieraan moge vastgeknoopt worden een korte beschouwing over de gesubstantiveerde infinitivus. HOFMANN Umg. Spr. p. 161 wijst erop, dat Martialis hiervan meerdere voorbeelden biedt. Toch vond ik er slechts enkele; zo I 89, 2 garrire et illud, teste quod licet turba. (FRIEDLAENDER, steunend op Italici, leest garris); V 83, 2 velle tuum nolo, Dindyme, nolle volo; misschien mag hierbij ook genoemd worden sp. 12, 4 O Lucina ferox, hoc peperisse fuit? Een dergelijke infinitivus is meer "energetisch" dan een abstract substantivum. 


\section{Conclusies}

Daar men na het lezen van de voorafgaande bladzijden wellicht de indruk zou kunnen hebben, dat Martialis' taal primair de neerslag is van de omgangstaal van die dagen, zal men er goed aan doen te bedenken, dat een onderzoek naar de invloed van de omgangstaal in Martialis' gedichten tenslotte toch slechts één facet van de kleurrijke taal van onze dichter belicht. Men denke b.v. aan de - reeds in de inleiding genoemde - dissertatie van WAGNER, die de invloed van de Augusteïsche dichters op Martialis' oeuvre behandelt; men herinnere zich, dat ik meerdere malen, het werk van AXELSON aanhalend, wees op de aanwezigheid van prozaïsmen, die nog niet per se popularismen behoeven te zijn; men herinnere zich voorts de in de literatuurlijst vermelde studie van JENS KRUUSE; kortom, men hoede zich er voor door de lezing van dit tractaat een al te eenzijdige opvatting van Martialis' taal te krijgen.

Beter is het Martialis als een typisch vertegenwoordiger van de literatuur van de eerste Keizertijd te beschouwen; het is immers in deze tijd, dat de herinnering aan en de nawerking van de als klassiek geldende modellen duidelijk waarneembaar is; het is eveneens de tijd, waarin de vervaging van de grenzen tussen poëtische en prozaïsche stijl optreedt, en waarin de invloed van de omgangstaal op de literaire taal steeds groter wordt, een tendenz, die bij Martialis wel zeer sterk werkt. Het valt dan ook slechts te betreuren, dat men tot op heden het rijke materiaal, dat Martialis' epigrammen bevatten, in 't algemeen gesproken, practisch verwaarloosd heeft. Een tekortkoming, die niet alleen nadelig is voor onze kennis van de Latijnse taal in het algemeen, maar ook voor het verstaan van Martialis zelf in het bijzonder. Hier springen de tekortkomingen van FRIEDLAENDERS commentaar wel zeer duidelijk in 't oog; DOLDERER formuleert dit aldus (p. 5 v.): „Inhaltliche Kommentiertätigkeit gibt meist nur das freilich unerlässliche, erste Rüstzeug für den modernen Menschen, der die zeitgeschichtlichen Bedingtheiten nicht kennt; auf Formkunst zu achten, ist antik wie modern, und damit erst geben wir allgemein Bedeutsames. Lessing sagt einmal: „Was durch Gelehrsamkeit in den alten Dichtern zu erklären stand, das ist uns, die wir jetzt leben, ziemlich vorweg genommen. Aber auf mein Wort! von dem, 
was sich in ihnen bloss durch Geschmack und Empfindung erklären lässt, ist uns noch manches übrig gelassen".

De invloed van de omgangstaal bij Martialis wordt wel duidelijk geïllustreerd, wanneer we ter vergelijking enige andere auteurs aanhalen, die eveneens popularismen in hun taal toelaten. Bezien we allereerst Petronius, die chronologisch niet zo ver van Martialis verwijderd is. Hoewel de schrijver van het Satiricon ook in het overige deel van zijn oeuvre wel omgangstaalelementen biedt, zijn het toch speciaal enkele vastomlijnde passages, waar de popularismen als het ware opgestapeld liggen overeenkomstig de uitdrukkelijke bedoeling van de auteur. Hierdoor krijgen deze populaire elementen een stilistische waarde. Bij Martialis valt van een dergelijke duidelijke scheidslijn niets te bespeuren; de gegevens, in het voorafgaande bijeengeplaatst, liggen in werkelijkheid over Martialis' gehele oeuvre verspreid. Zou men willen nagaan of Martialis in enkele van zijn boeken meer omgangstaal biedt dan in de rest van zijn werk, dan zal men tot de bevinding komen, dat dit een vrijwel vruchteloos werk is. Meer succes zou men a priori kunnen verwachten bij 't aannemen van de diverse metra als indelingsprincipe. Ondanks de suggestieve berekening van STEPHANI ben ik echter van mening, dat er ook in dit opzicht geen scheidslijn valt te trekken. Een verklaring hiervoor ligt naar mijn mening in het feit, dat Martialis, die aan de disticha kennelijk de voorkeur geeft, de overige metra voornamelijk gebruikt om een zekere afwisseling te verkrijgen, hetgeen wel blijkt uit de wijze, waarop hij zelf de verschillende versmaten op elkaar laat volgen. Bovendien is het duidelijk, dat het verschil in metra niet gepaard gaat met een verschil in behandelde onderwerpen; en het is logisch, dat Martialis, ondanks de variaties in zijn metra toch eendere zaken besprekend, ook in zijn taal, en met name in zijn woordgebruik, zich primair zal richten naar zijn onderwerpen; toch mag men hieruit niet concluderen, dat bij Martialis de popularismen op de eerste plaats een stilistische waarde hebben, zoals dat bij Petronius het geval is. Ik geloof, dat zij bij Martialis allereerst een kwestie van taal, en vervolgens pas een kwestie van stijl zijn.

BERTSCHINGER, die de taal van Phaedrus behandelt, geeft op p. 5 als zijn mening te kennen, dat de grondslag van Phaedrus' taal gevormd wordt door het proza; daar deze fabelverteller echter dichter wil zijn, ontleent hij veel aan de dichtertaal, zoals die te vinden is in de werken van de Augusteïsche tijd. 
Ik haal dit slechts aan om een juist beeld te verkrijgen van Martialis' taal en ik onthoud mij dus van een oordeel over de juistheid van BERTSCHINGER's opvatting. Ik meen echter wel te mogen zeggen, dat Martialis op de eerste plaats dichter is, en dat andere dan dichterlijke elementen, hoe belangrijk bij Martialis dan ook, pas op de tweede plaats gesteld dienen te worden.

Een vergelijking met Catullus mag hier allerminst achterwege blijven. Gebrek aan materiaal en de aanwezigheid van vaak al te grote lacunes zijn wel de belangrijkste redenen, die ' $t$ voor ons moeilijk maken een letterkundige geschiedenis van het Latijnse epigram te schrijven. En practisch onmogelijk is het, op enige vaste gronden de taalkundige tendenzen vast te stellen, die de ontwikkeling van het epigram beheerst hebben.

Vrijwel de enige dichter, die licht kan brengen in deze zaak is Catullus. Ik moge hier verwijzen naar de beschouwing van A. SEITZ, die op linguistische gronden bewijst, dat er een duidelijk onderscheid bestaat tussen verschillende delen van Catullus' oeuvre. De drie gedeelten, die hij onderscheidt, omvatten a) de carmina $1-60$; b) 61-64; c) 65-116 (65-68 vormen als het ware de overgang van het tweede naar het derde gedeelte). De delen a) en c) nu bevatten zeer veel omgangstaalelementen, die we ook bij Martialis weer terugvinden. De gedichten van het derde gedeelte noemt SEITZ zonder meer epigrammen. Voor ons is momenteel het voornaamste, dat Martialis in deze dus een blijkbaar bestaand gebruik handhaaft, en zelfs meer dan dat.

In de inleiding zeide ik, de grenzen van het begrip omgangstaal voorlopig ruim te willen trekken. Thans echter kunnen we, het gehele materiaal overziende, trachten de juiste plaats te bepalen, welke Martialis in dit opzicht inneemt. Hoewel Martialis zeker sommige elementen heeft, die we uitdrukkelijk als vulgair dienen te bestempelen, - men denke b.v. aan woorden en uitdrukkingen, die dienen ter aanduiding van zeer obscene begrippen, al dienen we deze dan ook te bezien in 't licht van de opvattingen van Martialis' dagen -, is het toch zo, dat deze slechts een gering percentage bedragen van het totale aantal omgangstaalelementen; anderzijds moest ik ook op verschillende plaatsen concluderen, dat een bepaald verschijnsel weliswaar tot de omgangstaal diende gerekend te worden, maar dat 't toch ook gebezigd werd in de culturele omgangstaal van de hogere standen. Al zal 't natuurlijk steeds moeilijk blijven, om de grenzen tussen de verschillende lagen nauwkeurig te bepalen, 
hel is toch duidelijk, dat de elementen, die in mijn studie ter sprake kwamen, voor 't merendeel genomen zijn uit de omgangstaal van de grote middelklasse van de Romeinse bevolking. Al zijn er in Martialis' oeuvre zeker elementen te vinden, die bewust ontleend schijnen te zijn aan de beide zo juist genoemde uiterste polen, dan mogen we er toch rekening mee houden, dat Martialis, als niet geboren en getogen Romein, de fijnere nuances, die de verschillende taal-lagen van elkaar onderscheidden, niet zuiver heeft aangevoeld; een overweging die trouwens bij de beoordeling van het gehele probleem van belang is: het is zeer wel mogelijk, dat Martialis het onderscheid tussen het gesproken en het literaire Latijn niet volkomen heeft kunnen aanvoelen, zeker waar in zijn dagen dit onderscheid toch al begon te vervagen.

Het is dus duidelijk, dat Martialis' omgangstaal-elementen thuis horen in de taal van die groepen van de Romeinse bevolking, waartoe wel 't merendeel van Martialis' lezers behoord zal hebben; het zullen eveneens diezelfde groepen zijn, waarin Martialis het meest verkeerde, gezien zijn persoonlijke levensomstandigheden.

O.a. door te appelleren aan de taal van deze grote middelklasse, had Martialis onmiddellijk contact met en de belangstelling van zijn lezers. Hier is van toepassing wat JENS KRUUSE, zij 't in een ander verband, opmerkt (p. 265) : „Il se rend compte que, pour que son lecteur s'aperçoive de sa plaisanterie, il faut que le chemin qui y conduit soit sans obstacles".

Ik heb de indruk, dat het dienen van zijn lezers bij Martialis voorop staat, wanneer hij omgangstaalelementen in zijn epigrammen gebruikt, en dat hij ze niet primair bezigt voor stilistische doeleinden.

Tenslotte zij nog opgemerkt, dat Martialis aan popularismen van phonologische aard ons, alles tesamen genomen, slechts weinig biedt; het zwaartepunt ligt bij hem op een ander terrein. Het was bovendien in het eerste deel van deze studie, dat we de meeste moeilijkheden ondervonden in verband met de juiste overlevering van de tekst. Het derde gedeelte, dat de syntaxis behandelt, bevat belangrijk materiaal van zeer uiteenlopende aard. Martialis is dus menigmaal afgeweken van de Klassieke norm; hier en daar, b.v. op 't gebied van de pronomina, kondigt zich bij hem reeds de toestand aan, die in het laat-Latijn algemeen zal worden. Juist de popularismen op syntactisch gebied kunnen we tot de belangrijkste rekenen, omdat hier de struc- 
tuur van de taal steeds weer doorbroken wordt. $\mathrm{Al}$ maken de syntactische popularismen numeriek misschien geen overweldigende indruk, dan zijn zij van de andere kant toch juist door hun qualiteit van zeer groot belang. Het is overigens nog de vraag, of Martialis aan syntactische omgangstaalelementen ons wel veel meer had kunnen bieden; zeker in de eerste eeuw zal de afstand tussen de cultuurtaal en de omgangstaal t.a.v. de syntaxis, nog niet zó groot geweest zijn. Het merendeel der popularismen echter behoort tot de woordenschat van Martialis; hiertoe behoren dan weliswaar ook woorden, die dienen ter aanduiding van min of meer obscene begrippen, maar ook met weglating van deze blijft het tweede, het vocabulaire gedeelte, zeker quantitatief, maar in vele opzichten ook qualitatief, het belangrijkste. Ook hierin geeft Martialis ons een juist beeld van de omgangstaal van zijn tijd, die zich wel voornamelijk in haar vocabularium van de cultuurtaal zal hebben onderscheiden. 


\section{KURZER UEBERBLICK.}

Der Dichter M. Valerius Martialis (von \pm 45 bis $\pm 104 \mathrm{n}$. Chr.) kam im Jahre 64 aus dem spanischen Bilbilis nach Rom. Er gehört der Periode an, die wir die Silberne Latinität zu nennen pflegen; es ist die Periode, in der die Nachwirkung der als klassisch geltenden Muster deutlich merkbar und der Einfluss der Rhetorik im allgemeinen gross ist. Die Grenzen zwischen der Dichtersprache und der Prosa fangen an sich zu verwischen, während volkstümliche Elemente und Gräzismen immer zahlreicher in das literarische Latein eindringen. In den Gedichten Martials ist der rhetorische Einschlag auf ein Minimum zurückgedrängt, die volkstümlichen Elemente finden sich aber desto zahlreicher.

Obgleich mehrere Forscher den volkstümlichen Einschlag in den Gedichten Martials erwähnen, hat bisher keiner eine Spezialuntersuchung über dieses Thema angestellt; auch der Kommentar der Standardausgabe FRIEDLAENDERS bedarf in linguistischer Hinsicht dringend einer Ergänzung.

In dem ersten Teil der vorliegenden Arbeit kommen einige phonetische Elemente zur Sprache; zunächst der Wechsel von au-o: der Diphthong au behauptet sich in der Kultursprache im allgemeinen länger als in der Sprache der Landbevölkerung und des einfachen Volkes. Martial hat neben 5-maligem cauda vielleicht an einer Stelle (VII 78,1) coda, neben 8-maligem copo vielleicht III 58,24 caupo; neben plaudo nie plodo; weiter hat er olla (=aula), Olus für Aulus, an 4 Stellen coliculus (Dimin. von caulis). Auch lesen wir bei ihm lomentum und focale; die Dublette lautus/lotus müssen wir ausser Betracht lassen, weil mit dem Vokalunterschied ein Bedeutungsunterschied verbunden ist ( lautus = „vornehm, reichlich"; lotus = „gewaschen"). Der Wechsel zwischen $a u-u$ zeigt sich im Simplex cludo (für claudo); dies ist aber nich ausschliesslich der Volkssprache eigen. W. HERAEUS (Rhein. Mus. 74 p. 334) sagt, dass Martial synkopierte Formen (periclum u.a.) nicht verwendet; doch lesen wir folgendes: balneum (sogar an 22 Stellen), balneator, caldus, calda, calfacio, lamna, lardum, prendo (für prehendo), soldum, surpuit (= surripuit), tomaclum; sogar lesen wir IV 44, 1 Vesbius für Vesuvius! 
$\mathrm{Zu}$ Martials Zeiten wurde here (nicht heri) gesprochen (cf. Quintilian, Inst. 1, 4, 8); in seinen Gedichten hat Martial an 6 Stellen here; das zwei-malige heri wird von ihm nur als Versende im Pentameter verwendet; nach der Meinung HERAEUS' ist dies die geeignete Stelle für dieses Wörtchen.

Auf dem Gebiete der Konsonanten finden wir folgendes: I 109, 1 steht Issa, die volkstümliche Form von ipsa; weiter lesen wir susum für sursum, tisana für ptisana; XI 21, 7 lesen wir aber phthisicus, nicht das volkstümlichere tisicus (Petron.)

Diese Beispiele zeigen deutlich, dass in den Epigrammen Martials phonetische Elemente volkstümlicher Art vorhanden sind, dass aber anderseits ihre Anzahl nur ziemlich gering ist.

In dem zweiten Teil wird das Vokabularium behandelt. Zunächst hat Martial insgesamt an 174 Stellen Interjektionen verwendet, von welchen die volkstümlichsten sind: eheu, ecce, euge, sophos (substantiviert!), mehercules; ausserdem hat er die Selbstverfluchung dispeream und ne valeam an mehreren Stellen. Die meisten Interjektionen stehen in Daktylen, nicht in Hendek. oder Choliamben, wo man sie von vornherein erwarten sollte.

Martial hat \pm 100 Diminutivbildungen mit einer Totalfrequenz von mehr als 400. Die Anwendung von Diminutiven ist an sich schon beliebt in der Umgangssprache; Martial aber verwendet sie oft auch ohne die streng diminutive Bedeutung. Die Abschwächung dieser Bedeutung geht ausserdem aus der Beifügung von parvus (sogar parvulus), oder einem anderen Adjektiv in Diminutivform hervor. Ausserordentlich volkstümlich sind die adjektivischen Diminutive, von denen Martial u.a. hat: bellus, misellus, parvulus, pusillus, putidulus, vetulus. Von den substantivischen Diminutiven nennen wir bucella, thermulae, umbella, cenula, ofella, vernula, matella und testiculi. Mehrere dieser Diminutivbildungen findet man schon bei Katull; so libellus, das vielleicht der feststehende Ausdruck war für ein Buch des epigrammatischen Genres. An einigen Stellen schreibt Martial munusculum, sogar parva munuscula. Volkstümlich sind auch ancilla, arcula, auricula (= auris), catella.

Obgleich Martials Auswahl aus sinnverwandten Wörtern an einigen Stellen von dem Versmasse oder von dem Streben nach Abwechslung bestimmt wird, kann man doch nicht immer auf diesen Grund hinweisen. Martial verwendet u.a. die folgenden Dubletten: bellus/pulcher; basium/osculum; bucca/os; 
invenire/reperire; pulchre/bene; subito/repente; zuweilen lesen wir quaerere (=velle) und homo (für Pronomen is). Der Unterschied zwischen propter und ob zeigt sich deutlich in IX 22, $1,2$.

STEPHANI legt oft einen zu grossen Wert auf die Suffixe: ein Wort ist nicht an sich schon volkstümlich, weil es mittels eines bestimmten Suffixes gebildet ist. So ist das Suff. -osus wohl beliebt in der Sprache der Bauernbevölkerung und des niederen Volkes. Jedoch ergibt sich, dass ambitiosus, animosus u.a. nicht volkstümlich sind. Auffallend ist der häufige Gebrauch der Abstrakta auf -(i) tas; diese Abstrakta sind typisch für das silberne Latein; Martial verwendet sie bisweilen pro concreto: so pietas und aetas in VI 85, 7.

Adverbien auf $-e,-o,-(i)$ ter, nicht sehr zahlreich in der höheren Dichtersprache, hat Martial auffallend oft verwendet. Die übrigen Adverbien haben oft einen volkstümlichen Charakter; so z.B. die Verbindung von bene und male + Adjekt.; diligenter und plane für abgenutztes valde (bei Martial nur an einer Stelle!); libenter ist prosaisch, vielleicht auch populär. Das substantivische mane hat Martial an 3 Stellen; omnino kommt wohl nur in den niederen Genren vor (Martial hat es 6-mal). Bisweilen ist pulchre gleich bene; das umgangssprachliche pulchre est hat Martial (vielleicht) in XII 17, 9; auch schreibt er taliter und qualiter für ita und ut.

Die Verwendung von Verbalkomposita wird nicht nur durch das Versmass bestimmt (SCHNEIDER!). Commemorare z. B. lesen wir nirgends bei Martial, wohl memorare, das der Umgangssprache, der daktylischen Poesie und der silbernen Prosa eigen ist. Dasselbe gilt für monstrare und demonstrare. Das vulgäre disperire hat Martial an 6 Stellen. Volkstümlich ist imponere (= "trügen"); das Simplex ponere (= apponere, „Speisen auftragen") wird in der Umgangssprache bevorzugt.

Die Frequentativa haben bei Martial nahezu immer ihre ursprüngliche Bedeutung beibehalten; eine Verstärkung dieser urspr. Bedeutung mittels saepe, semper, u.a. hält Martial offenbar nicht für nötig. Bisweilen umschreibt er folgendermassen: semper agis causas (I 79, 1: dakt.) cf. actitare causas (I 17, 1: hendek.). Mehr populär sind die Desiderativa auf - $(t)$ urire: so cenaturire, cacaturire.

„Allerweltsverba" (dare, facere, habere) dienen oft zur Umschreibung anderer Verben, was vor allem in der Umgangssprache vielfach vorkommt. So finden wir bei Martial an 
mehreren Stellen verba dare („trügen"), basia (oscula) dare (= basiare, osculari); nomen habere (= nominari).

Die Gräzismen sind sehr zahlreich bei Martial und oft volkstümlich; dennoch wird ihr Wert von STEPHANI vielfach übertrieben. Martials Kenntnis der griechischen Sprache reicht weiter als die in dem gesprochenen Latein seiner Tage üblichen Wörter; dies geht u.a. aus Wortspielen (Palinurus, Argonautae, clinicus) deutlich hervor. Eine Beurteilung der Gräzismen darf sich nicht auf die ganze Gruppe als solche gründen oder bloss auf die nova; jedes einzelne Wort soll behandelt werden. Epaphaeresis z.B. (VIII 52, 9) ist wahrscheinlich nicht volkstümlich. Ausserdem hat Martial oft die ursprünglichen griechischen Kasusendungen beibehalten (Akk. tropin, u.a.) Ferner ist in diesen Teil eine grosse Liste volkstümlicher Wörter aufgenommen, die nicht zu einer der oben erwähnten Kategorien gehören. Man findet sie auf Seite $70 \mathrm{ff}$.

Der dritte Teil enthält syntaktische Eigentümlichkeiten. Zunächst wird das ,verschobene" Plusquamperfekt besprochen, eine Erscheinung, die namentlich in der volkstümlichen Sprache vorkommt. Meiner Meinung nach bietet Martial 27 Beispiele dieser Tempusverschiebung, welche grösstenteils in Daktylen stehen. Auffallend ist, dass das verschobene Plusq. Perf. von Martial meist in Hauptsätzen verwendet wird. Martial geht also weiter als viele andere Autoren, die es hauptsächlich in Nebensätzen schreiben. Auch die Form credideram kommt hier in Betracht; die Ansicht von BLASE S. 75 ist nicht richtig. Martial hat auch mehrere Beispiele eines Partizips Perf. Pass. + fui, fueram, usw. für sum, eram, usw. Die Fälle mit fueram stehen wieder hauptsächlich in Hauptsätzen; fui lesen wir sogar an 7 Stellen! Die Verwendung des (selbständigen) fuero statt ero ist alt und populär, aber hier handelt es sich nicht um eine Tempusverschiebung. Martial bietet 4 Beispiele.

Unter den Fragesätzen Martials gibt es sehr viele, die nicht durch eine Fragepartikel eingeleitet werden. Die Partikel -ne, die in der Kaiserzeit und namentlich in der Umgangssprache immer seltener wird, hat Martial nur in beschränktem Masse verwendet. Nonne fehlt ganz, num steht nur an einer Stelle; das volkstümliche numquid aber wird wiederholt von Martial verwendet. Auch ecquis (an 2 Stellen) und ecquid (an 6 St.) sind volkstümlich; dasselbe gilt von $u$ t quid (= cur; an $3 \mathrm{St}$.). Die Formeln quid ergo, quid quod, quid si lesen wir 28-mal. Auch bei den (weniger zahlreichen) disjunktiven Fragen finden 
wir öfters volkstümliche Elemente, z.B. utrum(ne) -an. Si wird als Fragepartikel (in einem abhängigen Fragesatz) nur einmal von Martial geschrieben (III 14, 5f.).

Die Beiordnung im Satzbau spielt bei Martial eine wichtige Rolle. Es sind nicht nur bestimmte Verben (oro, precor, puto, rogo, u.a.) oder Formeln (dic mihi, crede mihi) die öfters parataktisch eingeschaltet werden: auch ein untergeordneter Konjunktionalsatz wird sehr oft ersetzt durch eine beigeordnete Konstruktion (vor allem in Konditionalsätzen). Gleichfalls kommt die Parenthese häufig vor.

Bei den Neutra (der 2. Dekl.) werden die Formen auf -a (715-mal) vor den Singularformen auf -um von Martial bevorzugt (276-mal); im Genitiv und Dativ verwendet er vorzugsweise die Singularformen. Schon bei Martial finden wir einige Spuren der Entwicklung des Akkusativs in der Richtung des Kasus generalis (so ist die in einigen Hss. vorkommende Lesart III 80, 1 nullum (statt nulli) maledicis, nicht an sich unmöglich).

Unter den Präpositionen nimmt de eine hervorragende Stelle ein; cf. fugere de (IX 88, 4); implere de (XIV 12, 1); dicere (loqui) de (u.a. III 80, 1), usw.

Es zeigt sich, dass das Pronomen Personale manchmal unnötig verwendet ist: daraus ergibt sich die Mechanisation dieses Pronomens (besonders $t u$ !). Von den distributiven Zahlwörtern, deren man sich meistens im Plural bedient, begegnen wir bei Martial auch einigen Singularformen. Die Verwendung von Wörtern als perinanis, pertricosus, u.a. statt eines Superlativs ist gleichfalls volkstümlich.

Die Inversion der Kopula et hat Martial an \pm 60 Stellen (z.B. IX 59, 12). Die Verstärkung des Imperativs mittels $i$ (nunc) findet sich zunächst in der Volkssprache (z. B. X 96, $13 i$, cole nunc reges). Volkstümlich ist cave (und parce) + Infinitiv (für ne + Konj.), und fac + Konj. (fac me ames = ama me). Ein Beispiel dafür, dass der Akk. c. Infin. ersetzt wird durch eine analytische Konstruktion mit quia oder quod, noch selten im 1. Jahrhundert n. Chr., lesen wir in XI 64, 2 (scio quod + Indik.). Ein wenig zahlreicher sind die Stellen mit einem substantivierten Infinitiv.

Im Vorhergehenden haben wir nur darzulegen versucht, wo man in den Werken Martials volkstümliche Elemente finden kann. Nur das Wichtigste wurde in diesem Ueberblick gestreift. Aus unseren Ausführungen geht aber klar hervor, dass Martial ein typischer Vertreter der Sprache des 1. Jahrh. n. Chr. ist. Es 
ist denn auch zu bedauern, dass der Dichter in dieser Hinsicht bisher zu wenig benutzt worden ist. In seinen Gedichten können wir die Verwischung der Grenzen zwischen Poesie und Prosa und den Einfluss der Umgangssprache sehr deutlich feststellen. Die volkstümlichen Elemente sind über das ganze Werk zerstreut (cf. Petron.!): wir finden sie in Daktylen, aber auch in den übrigen Versmassen. Ausserdem gehören die genannten Elemente bei Martial eher dem Gebiete des Stils als dem der Sprache an. Aus unserer Untersuchung ergibt sich weiter, dass die umgangssprachlichen Elemente nur vereinzelt der Sprache des höheren Standes und der niedrigsten Volksschicht entlehnt sind; die Mehrzahl gehört der Sprache der Mittelklasse der Bevölkerung Roms an. Die phonetischen Popularismen spielen nur eine untergeordnete Rolle; wichtig ist das dem volkstümlichen Vokabular entlehnte Material, während die syntaktischen Elemente vor allem qualitativ von grosser Bedeutung sind. 



\section{Zaak- en woord-register}

accusativus $108 v$

a c c. c. infin. $\mathbf{1 1 5}$

adverbia $62 v v$

alapa 70

alica-alicula $34 \mathrm{v}$

"A l lerwe l tsverba" $66 v$

an $92,95 v v, 97,99$

antequam 70

anus 70

apinae 70

(ap) ponere 66

asellus $41 \mathrm{v}$

aula-olla 16

auricula 17, 42

bal(i)neum 18

basium-basiare 48,67

bellus-belle 29,46

bene + adiect. 63

bucca 33,49

caballus 49

cacare 71

capo 71

caput 71

cauda-coda 15

caudex-codex 15

caupo-copo 15

cave + infin. 114v

cenula 35

cerdo 71

cito 25

cludo $17 \mathrm{v}$

coleus 72

coliculus 16, 37

(com)edere $51 \mathrm{v}$

composita $64 \mathrm{vv}$

concurbinus 45

conditionelezinnen $103 v v$

confiteor 102

crede mihi 102

credideram 87

crepare 72

cur 94, 99

de $109 \mathrm{v}$

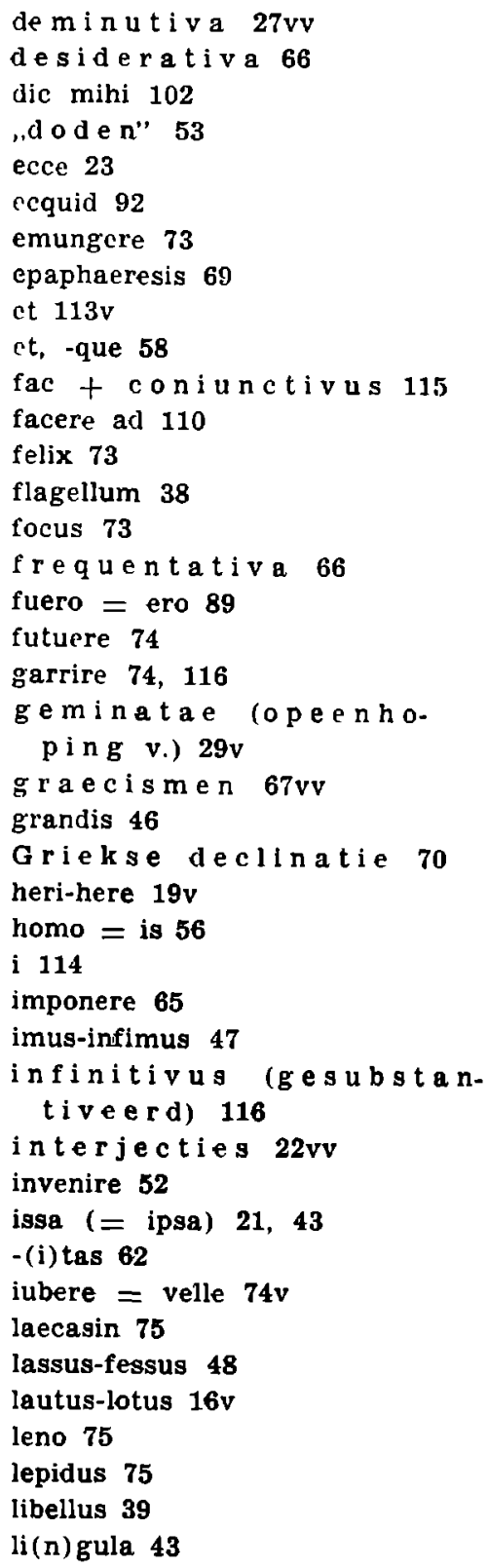




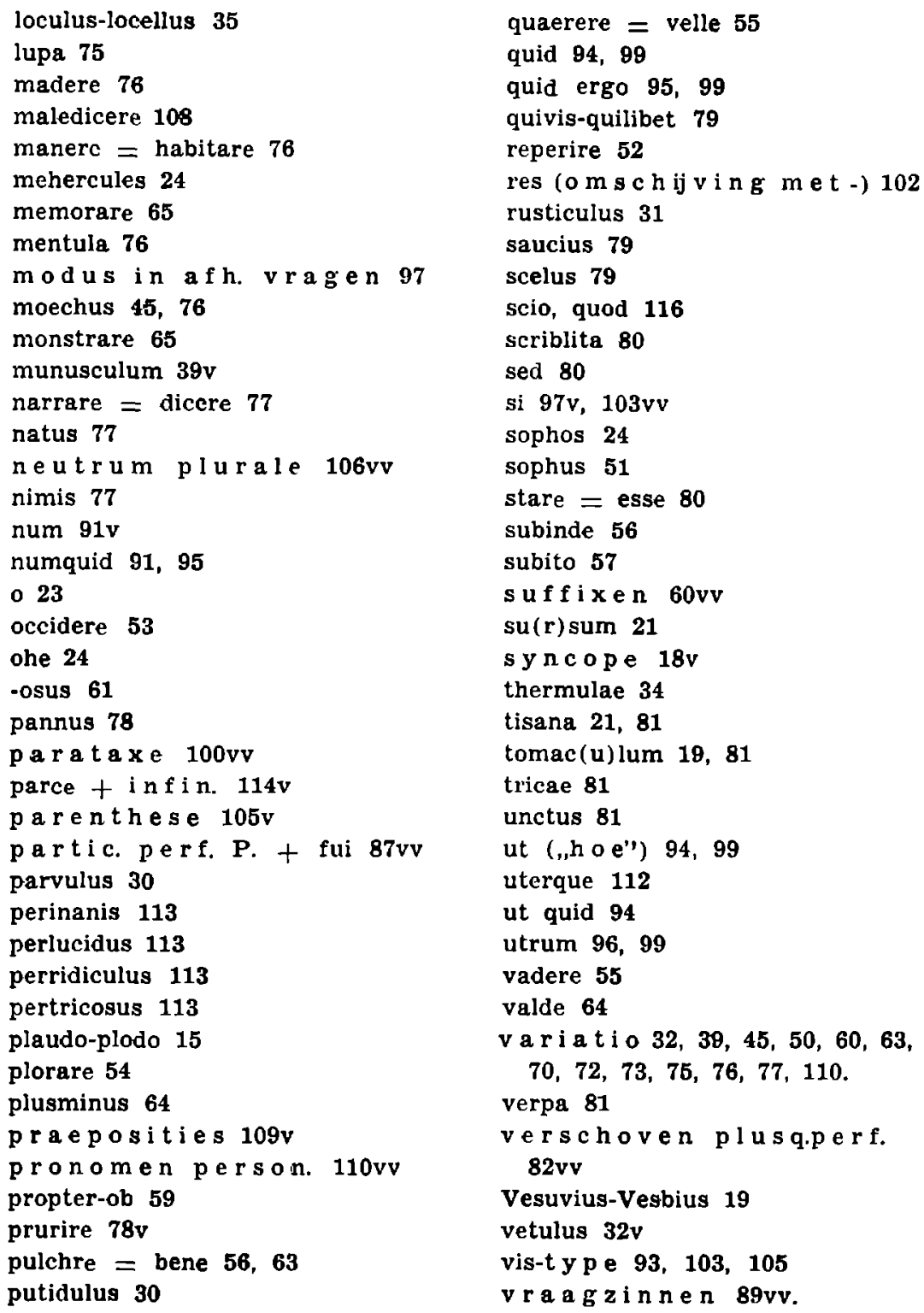




\section{Inhoudsopgave}

LITERATUURLIJST

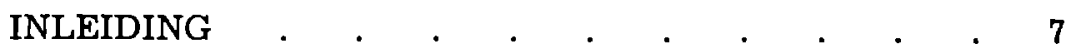

HOOFDSTUK I. Enige kwesties van phonetische aard 14

$\S 1$. De afwisseling $a u: \bar{o} . \quad$. . $\quad 14$

$\S 2$. De afwisseling $a u: \bar{u}$. . . . . . . 17

§ 3. Syncope . $\quad . \quad$. $\quad . \quad$. . . . 18

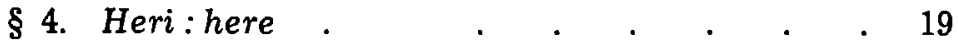

§5. Consonanten . . . . . . . . 20

HOOFDSTUK II. Het vocabularium . . . . . 22

$\S 1$ 1. De interjecties . . . . . . . . . 22

§ 2. De deminutiva . . . . . . . . . . $\quad$. 27

a) Eigennamen . . . . . . . $\quad .27$

b) Adjectiva .. . . . . . . . . $\quad .29$

c) Substantiva $\quad . \quad$. $\quad . \quad$. $\quad . \quad$. 32

d) Deminutiva, die Martialis met Catullus gemeenschappelijk heeft . . . . 38

e) De overige deminutiva . . . . . 40

§ 3. Het gebruik van synoniemen . . . . 45

a) Adjectiva . . . . . . . . 46

b) Substantiva . . . . . . . . 48

c) Verba . . . . $\quad . \quad . \quad . \quad 51$

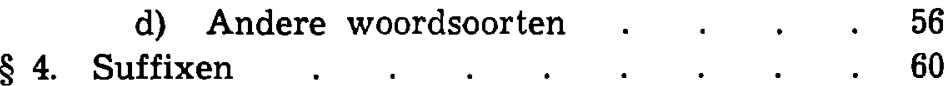

§ 5. Adverbia . . . . . . . . . . . $\quad .62$

§6. Het gebruik van verbaal-composita . . . 64

\$ 7. De frequentativa en desiderativa . . . . 66

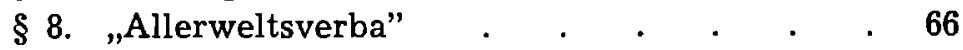

§ 9. Graecismen . . . . . . . . . . . . $\quad$. 67

$\S 10$. Lijst van populaire woorden, voorzover niet in de voorafgaande $\$ \S$ behandeld . . . 70

HOOFDSTUK III. De syntaxis . . . . . $\quad$. 82

$\S 1$. Het verschoven Plusquam-Perfectum.

a) Algemene opmerkingen . . . $\quad 82$

b) Het verschoven Plusq.Perf. bij Martialis $\mathbf{8 4}$

c) Participium Perf. Pass. + fui, etc. . . 87 
§ 2. De vraagzinnen.

Groep IA: Een-ledige directe vragen . . 90

Groep IB: Disiunctieve directe vragen . . 95

Groep IIA: Een-ledige indirecte vragen . 97

Groep IIB: Disiunctieve indirecte vragen . 99

§ 3. De paratactische zinsconstructie . . . 100

a) Verba dicendi, sentiendi e.d.; vaak paratactisch gebruikt . . . . . 101

b) Parataxe i.pl.v. coniunctionele, hypotactische constructie . . . . . 102

c) Parenthese . . . . . . . . 105

§ 4. De neutra . . . . . . . . . . 106

$\S 5$. Het gebruik van de accusativus . . . 108

$\S 6$. Het gebruik van praeposities . . . . 109

§ 7. De pronomina en distributiva . . . . 110

$\S 8$. De vervanging van de superlativus . . . . 113

§ 9. De inversie van de copula et. . . . . . . 113

$\S 10$. Versterking van de imperativus door $i$. . . 114

$\S 11$. Enkele infinitivus-constructies . . . . 114 CONCLUSIES . . . . . . . . . . . . 117

KURZER UEBERBLICK $\quad . \quad . \quad$. 122

REGISTER $\quad . \quad . \quad . \quad . \quad . \quad . \quad . \quad .129$

INHOUDSOPGAVE $\quad \cdot \quad$. $\quad . \quad \cdot \quad \cdot 131$ 


\section{STELLINGEN}

I

Een systematisch stilistisch onderzoek van Martialis' epigrammen zou zịn kwaliteiten als dichter nog duidelijker in het licht stellen.

\section{II}

Hoewel het ons ter beschikking staande materiaal hiervoor zeer schaars is, is het mogelijk enige lijnen vast te stellen, waarlangs de ontwikkeling van het Romeinse epigram verlopen is.

\section{III}

Het is zeer moeilijk uit te maken, in hoeverre Martialis in linguistisch opzicht onder invloed staat van zijn voorgangers in het epigrammatische genre.

\section{IV}

De woord-index in Friedlaender's uitgave van Martialis' epigrammen (deel II, p. 382 vv.) is niet steeds betrouwbaar en moet derhalve met grote reserve gebruikt worden.

\section{$\mathrm{V}$}

Stephani hecht in het algemeen een te grote waarde aan de suffixen qua tales.

E. Stephani, De Martiale verborum novatore, Breslau 1889.

\section{VI}

Het metrum heeft menigmaal de woordkeus van Martialis beïnvloed; Schneider overdrijft echter vaak de invloed van het metrum.

G. Schneider, De M. V. Martialis sermone observationes, Breslau 1909. 
Het zou zeer wenselijk en, gezien het ons ter beschikking staande materiaal, ook mogelijk zijn om, naar het voorbeeld van J. B. Hofmann's Lateinische Umgangssprache, de tendenzen te beschrijven, die de Griekse omgangstaal beheerst hebben.

\section{VIII}

Frequentie-woordenlijsten zijn belangrijker voor didactische en stilistische dan voor taalpsychologische onderzoekingen.

\section{IX}

Het gebruik van het relatieve adverbium waar als causale conjunctie kan niet zonder meer als foutief worden beschouwd.

\section{$\mathrm{X}$}

Het verdient aanbeveling bij het lezen van de Griekse en Latijnse schrijvers de leerlingen de inhoud van het vertaalde te laten analyseren.

\section{XI}

De mogelijkheid is niet uitgesloten, dat we verband moeten leggen tussen Aulus Pudens (Martialis I 31, 3; e.a.), Pudens (2 Timoteus 4, 21) en Cornelius (Handelingen d. Ap. 10, 1 vv.), zonder hierbij onmiddellijk aan een volledige identificatie te denken.

\section{XII}

Ten onrechte wordt in de "Algemene Literatuurgeschiedenis", deel I, aan de epigrammatiek (en met name de Romeinse) te weinig aandacht geschonken.

Algemene Literatuurgeschiedenis, deel I (onder redactie van Prof. Dr. H. Wagenvoort), Utrecht z.j.

\section{XIII}

Het is opvallend, dat de regel van de Griekse syntaxis, dic verbiedt, bij een opeenvolging van twee (of meer) relatieve zinnen, het tweede relativum te schrijven, wanneer dit in een andere naamval zou moeten staan dan het eerste, in het algemeen gesproken eveneens op Vergilius (Aeneis) van toepassing is. 

